\title{
16. CARBONATE BUILDUP AND SEA-LEVEL CHANGES AT MIT GUYOT, WESTERN PACIFIC ${ }^{1}$
}

\author{
L.F. Jansa ${ }^{2}$ and A. Arnaud Vanneau ${ }^{3}$
}

\begin{abstract}
MIT Guyot is located in the northwestern Pacific Ocean, and the top of the guyot is at a water depth of $1323 \mathrm{~m}$. Drilling at MIT Guyot penetrated $719 \mathrm{~m}$ of shallow-water carbonates overlying volcanic substrate. The carbonates are of Aptian to late Albian age. Carbonate deposition was interrupted by a volcanic event, which separates the buildup into a lower and an upper sequence. Core recovery was very low, averaging only $4.3 \%$, and no recovery was made in several intervals. Therefore, wireline logs and a comparison with modern ocean islands and atolls were extensively used to interpret the geologic history of the MIT Guyot carbonate buildup.

Shallow-water carbonate construction began in a fringing "reef/bank" environment established around a subsiding volcano and was reestablished before and after a period of brief, late, volcanic eruption. Oolitic grainstones are the common lithologies of this phase. The remainder of the deposition occurred in an "atoll-like" environment, dominated by carbonate sand shoal and lagoonal facies. Finer grained lagoonal deposits make up $13 \%$ of the sequence. No true reefal facies were found in the cores; however, sporadic occurrences of coral-stromatoporoid, rudist bindstone, and floatstone (and their rubble) suggest the presence of bioconstructions at the seaward edge of the guyot, or localized within the shallow lagoon. Carbonate cement stratigraphy indicates that some of the grainstones were cemented by early marine cements, but the dominant diagenetic imprint is of the phreatic zone. The occurrence of meniscus cement is indicative of occasional cementation in the vadose zone. Unstable aragonite and high $\mathrm{Mg}$-calcite skeletal grains were replaced by low $\mathrm{Mg}$-calcite, which results in the development of high ( $20 \%-40 \%)$ interand intraparticle porosity. Trace element chemistry of the cements from MIT Guyot bears comparison with Pleistocene cements from Anewetak Atoll. The low magnesium and strontium concentrations in some of the cements probably reflect the influence of a freshwater environment on limestone diagenesis. The lowest concentration of strontium in neomorphically recrystallized micrites (chalky limestones), at the top of MIT Guyot, may argue for alteration within the vadose zone and subaerial exposure of the guyot surface before its final drowning.

Cyclic alternation of the keep-up and give-up phases during MIT Guyot carbonate buildup construction indicates seven flooding periods, which may correlate with third-order eustatic sea-level rises (cycles LZB-3.5 to LZA-1.5) within the late Barremian to Albian. The sudden demise of carbonate deposition, followed by subaerial emergence of the guyot surface, indicates a relative sea-level drop, which was probably a result of a regional tectonic uplift, before the guyot drowned.
\end{abstract}

\section{INTRODUCTION}

The ocean floor of the western Pacific is covered by numerous scattered seamounts and atolls. Most of the seamounts are guyots, which have flat tops and are considered to be old, drowned atolls (Hess, 1946). Some are clustered together; others, such as the MidPacific seamounts or the Marshall Islands, are aligned in a given direction. Other guyots, or clusters of guyots, may not show any particular orientation or they may be isolated features (Winterer et al., 1993), which is the case with the MIT Guyot and the poorly defined Japanese Seamounts located close to the Japan Trench. The summit of many of the guyots presently occurs at a water depth of about 1500 m (Matthews et al., 1974; Winterer and Metzler, 1984; McNutt et al., 1990), which is shallower than would be expected considering the elapsed time since the guyots' drowning and ocean-floor subsidence (Crough, 1984; McNutt et al., 1990). Current plate motion models indicate that the Cretaceous volcanoes in the northwestern Pacific were created in the southeast Pacific (Winterer et al., 1993), where hotspot volcanism and the late Cenozoic seamount chain presently exhibit similar peculiarities to the older Darwin Rise (Wolfe and McNutt, 1991).

Because of their position in the center of the ocean basin and their location on subsiding ocean crust, guyots are considered to be an ideal location to test Cretaceous eustatic sea-level changes (Lincoln and

'Haggerty, J.A., Premoli Silva, I., Rack, F., and McNutt, M.K. (Eds.), 1995. Proc. $O D P$, Sci. Results, 144: College Station, TX (Ocean Drilling Program).

${ }^{2}$ Atlantic Geoscience Centre, Bedford Institute of Oceanography, P.O. Box 1006 Dartmouth, Nova Scotia, Canada B2Y 4A2.

${ }^{3}$ Institut Dolomieu, Université de Grenoble, 15 Rue Maurice Gignoux, F-38031 Grenoble Cedex, France.
Schlanger, 1991; Wheeler and Aharon, 1991). Periods of emergence resulting from lower sea levels exposed limestones to intensive meteoric diagenesis, as drilling has shown on Anewetak Atoll (Schlanger, 1963; Wardlaw and Henry, 1986). Solution unconformities mark these periods of emergence. The timing of sea-level changes can be calibrated by analyzing the diagenetic history of deposited carbonates and the stratigraphic position of solution surfaces and their correlation between other guyots in the northwestern Pacific.

Ocean Drilling Program (ODP) Legs 143 and 144 were designed to search for the eustatic sea-level signal by drilling seven guyots in the western Pacific, spanning about $30^{\circ}$ of latitude and $35^{\circ}$ of longitude (see site map preceding the title page; Sager, Winterer, Firth, et al., 1993; Premoli Silva, Haggerty, Rack, et al., 1993). Sampling over broad regional areas was intended to provide a basis for separating tectonic and eustatic sea-level signals and to provide data about provincialism of the biota and migration routes.

One of the guyots drilled during Leg 144 was the MIT Guyot (Premoli Silva, Haggerty, Rack, et al., 1993). Drilling at Site 878 (MIT Guyot) recovered a thin veneer of pelagic deposits underlain by $719 \mathrm{~m}$ of shallow-water carbonates, which enclose a thick sequence of volcanic-limestone breccia and a portion of the volcanic edifice. The shallow-water carbonate strata are the main subject of this study. The aim is to reconstruct the history of the carbonate buildup and compare it to modern atolls, reefs, and carbonate platforms. Further objectives were to derive data about sea-level changes from both lithofacies and observed diagenetic changes within the carbonate sequence and to determine the genesis of the rough topography at the top of MIT Guyot. The latter was interpreted by Grötsch and Flügel (1992), van Waasbergen and Winterer (1993), and Winterer et al. (1993) to be the result of subaerial emergence of the limestone producing karst topography before final drowning. 


\section{Location}

MIT Guyot is centered at $27^{\circ} 15^{\prime} \mathrm{N}$ latitude and $151^{\circ} 50^{\prime} \mathrm{E}$ longitude, approximately halfway between the Japanese Seamounts to the north and the Marcus-Wake Seamounts to the south (see site map preceding the title page). The elongated guyot has a maximum length of more than $20 \mathrm{~km}$ and trends northeast-southwest. The edifice narrows from approximately $6 \mathrm{~km}$ in the southwest to less than $2 \mathrm{~km}$ in the northeast (Fig. 1). Magnetic Anomaly M29 is found slightly south of this guyot (Nakanishi et al., 1992), thereby making the oceanic plate on which the MIT seamount was constructed about 160 m.y. old.

The SeaBeam bathymetry obtained by van Waasbergen and Winterer (1993) shows the guyot surface to be rough, with isolated holes and mounds (Fig. 1). Some of the holes are more than $100 \mathrm{~m}$ deep. Consequently, van Waasbergen and Winterer postulated that the holes are dissolution features connected to some form of subsurface drainage system. The seismic reflection profile across the guyot (Fig. 2) shows a virtual absence of pelagic sediment at the top of this guyot. Site 878 was located at the northeastern side of the MIT Guyot, near its southern edge (Fig. 1), in a water depth of $1323 \mathrm{~m}\left(27^{\circ} 19.143^{\prime} \mathrm{N}\right.$ and $\left.151^{\circ} 53.028^{\prime} \mathrm{E}\right)$.

\section{Methods to Address Drilling Strategy Shortcomings}

The initial plan for the drilling program was directed toward the guyot carbonate cap and the study of eustatic sea-level fluctuations, but changes were made during the final planning stages to favor the study of geophysics and the volcanic basement. As a result, a single drilling site was located in the lagoonal region of each of the guyots drilled during Leg 144 (see site map preceding the title page) instead of a transect of at least three holes testing the lagoon, perimeter, and the upper slope of the carbonate buildups. Because only one lagoonal site was drilled at MIT Guyot, it is difficult to interpret fully the geologic history of the carbonate buildup and to answer some fundamental questions, such as:

1. Does the carbonate strata represent constructional features similar to those of modern atolls?

2. Is the seaward margin of the carbonate buildup seen as a seismically transparent zone (Premoli Silva, Haggerty, Rack, et al., 1993), the result of an accumulation of bioherms and reefs? or

3. Does it represent a diagenetically modified carbonate edge?

Only $2.3 \%$ of the core was recovered from the upper limestone sequence and $6.3 \%$ from the lower limestone sequence, and no cores were recovered in several cores. Thus, geologic interpretations of the guyot carbonate cap were seriously hindered. An additional difficulty arises from the high fragmentation of cores. Limestone fragments were only a few centimeters in length, and the total length of all of the fragments filled no more than $30-40 \mathrm{~cm}$ in each 9-m-long core barrel. The core fragments could have come from anywhere within the 9-m interval. The failure to obtain a single core with $100 \%$ recovery or even an unbroken core longer than $1 \mathrm{~m}$ not only inhibits the identification of exposure surfaces and changes in sediment composition related to sea-level fluctuation, but it also precludes confident correlation of the lithology with the wireline logs.

The lack of recovered cores required the use of methods similar to those used in the subsurface studies of carbonates (Asquith, 1979), based predominately on interpretation of wireline logs. Because core lithology could not be directly correlated with wireline log responses, an interpretation of wireline logs was used here to place the core fragments into stratigraphic position within the 9-m drill interval. The wireline log interpretation was augmented by shipboard core description, including information on limestone constituents, identification of biota, grain size, and porosity, as well as by results of a study of 200 thin sections. Shipboard descriptions of the cores are included in Premoli Silva, Haggerty, Rack, et al. (1993) and therefore do not appear in this paper.
Chemical analyses of carbonate cements from selected samples was performed to obtain information about the environmental niche of carbonate diagenesis. Some of the polished thin sections were scanned for high magnesium concentrations in bioclasts and cements using an X-ray energy dispersive spectrometer. The most representative samples of carbonate cements were selected for analyses of strontium and magnesium content in single crystals of the cement and in limestone skeletal constituents.

Analyses were conducted on a JEOL 733 electron microprobe equipped with four wavelength dispersive spectrometers and an Oxford Link exL energy dispersive system. Resolution of the energy dispersive detector was $137 \mathrm{ev}$ at $5.9 \mathrm{Kev}$. The energy dispersive system was used for all elements except $\mathrm{Sr}$, for which a wavelength spectrometer equipped with a TAP crystal was used. Each spectrum was acquired for $40 \mathrm{~s}$ with an accelerating voltage of $15 \mathrm{Kv}$ and a beam current of $15 \mathrm{nA}$. Probe spot size was approximately $5 \mu \mathrm{m}$. The raw data was corrected using Link's ZAF matrix correction program. Instrument calibration was performed on cobalt metal. Geological minerals were used as controls. Instrument precision on cobalt metal $(x=10)$ was $\pm 0.5 \%$. Accuracy for major elements was $\pm 1.5 \%$ to $2.9 \%$ relative.

\section{Application of Wireline Logs to Carbonate Study}

Several authors have successfully used various well-log crossplots to differentiate carbonate lithofacies (Basham and Dorfman, 1983; Keith and Pittman, 1983; Kamon and Dorfman, 1986; Stowe and Hock, 1988, Dorfman et al., 1990). However, some of the carbonate deposits in the MIT Guyot have porosities of more than $50 \%$, which affects the rock densities and made it difficult to use log cross-plot data from the petroleum industry for lithofacies interpretation. The wireline log responses from more lithologically homogenous and thicker zones were compared with lithofacies present in cores and studied in thin sections. The most useful logs for lithofacies identification were found to be the gamma-ray, sonic, neutron porosity, bulk density, resistivity, and dipmeter logs. The wireline logs used for interpretation are the depth-adjusted, BRG-Lamont processed well-log data on compact disk (CD-ROM) distributed with the Ocean Drilling Program Initial Reports volume (Premoli Silva, Haggerty, Rack, et al., 1993).

The above methods helped us to define the log responses of three major lithofacies: grainstone/packstone, wackestone, and lime mudstone (Fig. 3). The clean carbonates usually display a low gamma-ray signature. Variations in the natural radioactivity (natural gamma-ray emissions from the decay of potassium, uranium, and thorium) of the sediments at Site 878, in the absence of clays, are interpreted to reflect variations in the organic matter and uranium content as documented by the geochemical logs (Premoli Silva, Haggerty, Rack, et al., 1993). The organic matter and uranium content are higher in mudstone than carbonate sands. The shipboard geochemical analyses show up to $0.94 \%$ organic carbon in the wackestone at Hole $878 \mathrm{~A}$, with less than $0.09 \%$ organic carbon in the grainstone (Premoli Silva, Haggerty, Rack, et al., 1993). The lower gamma-ray counts usually correspond to lower density; variable, usually lower resistivity; and an increase in neutron porosity. This set of log responses is interpreted as indicative of carbonate grainstone and packstone facies. Wackestone and mudstone facies, in contrast, show increased gamma-ray counts and variable, commonly higher resistivity and density (Fig. 3). The relatively sharp high-density and low-porosity peaks, $0.5-1 \mathrm{~m}$ thick, within the grainstone packages may correspond to a tightly cemented carbonate bed, a limestone pebble or breccia bed, or a boundstone bed. However, the wireline logs do not differentiate these possibilities and, in such cases, the interpretation is based on the presence of these lithologies in the core fragments.

It was possible, therefore, to reconstruct a more detailed lithology for Site 878 than would have been possible using only samples from the recovered cores. Our approach allowed us to interpret the character of lithologic contacts between individual lithofacies and determine the depth of the lithofacies boundaries. Inclusion of petrographic data 


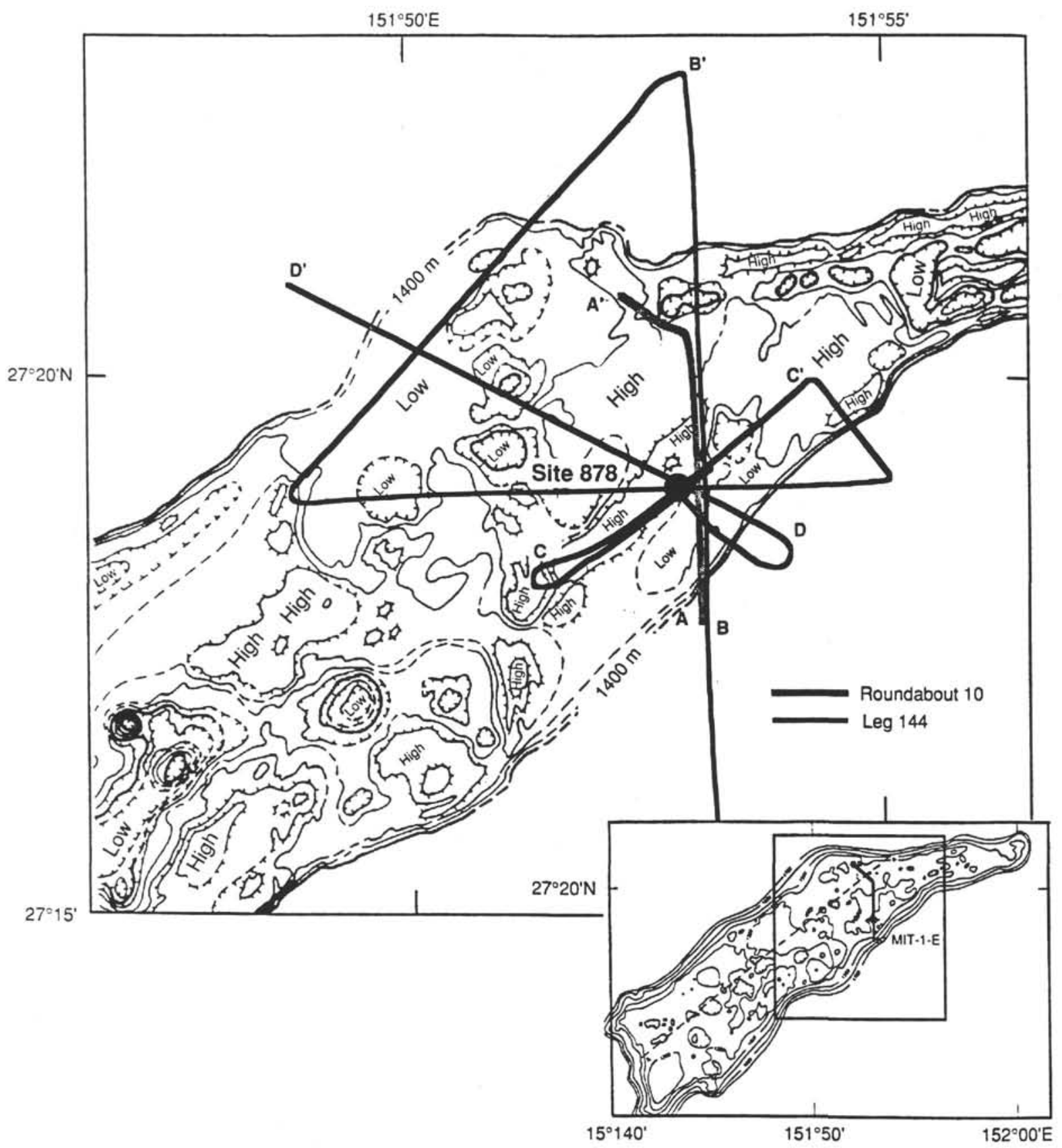

Figure 1. SeaBeam bathymetry and ship tracks across the summit of MIT Guyot. Bathymetric data were collected during Roundabout Cruise 10. Site 878 location is shown on the enlarged bathymetric map, which shows the rugged, uneven topography with circular holes. Profile B- B' $^{\prime}$ is shown in Figure 2 .

(Table 1) placed additional constraints on the interpretation of the geologic history of the carbonate buildup; it also allowed us to comment on relative sea-level changes and the processes leading to the drowning of the guyot. However, because of the poor core recovery, the interpretation of the carbonate strata is highly subjective. A significant role in our interpretation was played by the senior author's experience in oil-industry-related studies of subsurface carbonate and of modern reefs in the Pacific. This experience has been incorporated into the carbonate depositional history interpretation.

\section{STRATIGRAPHY}

Three holes were drilled at MIT Guyot. Hole 878A bottomed at 910 $\mathrm{m}$ below seafloor (mbsf) after penetrating $3.2 \mathrm{~m}$ of pelagic cover sediment, $719.34 \mathrm{~m}$ of shallow-water carbonates and polymictic brec- cias of basalt scoria and limestone clasts, and $187.46 \mathrm{~m}$ of basalt flows and flow-top breccia at the top of the volcanic edifice. Basalt at the top of the volcanic substrate was isotopically dated by the ${ }^{39} \mathrm{Ar} /{ }^{40} \mathrm{Ar}$ method on plagioclases as $119.6 \mathrm{Ma}$ (Pringle, this volume). No pelagic sediment was recovered in Holes $878 \mathrm{~B}$ and $878 \mathrm{C}$, where the platform carbonates immediately underlie the manganese-encrusted guyot surface. Holes $878 \mathrm{~B}$ and $878 \mathrm{C}$ only touched the surface of the guyot; thus, all the lithologic descriptions are derived from the study of Hole 878A.

The polymictic volcanic breccia, which is $205 \mathrm{~m}$ thick (399.7$604.3 \mathrm{mbsf}$ ), separates the carbonate sequence into a lower sequence, which is $118 \mathrm{~m}$ thick (604.3-722.5 mbsf), and an upper sequence, which is $397 \mathrm{~m}$ thick (3.2-399.7 mbsf; Fig. 4).

The volcanic breccia consists of highly vesicular scoria generally of medium lapilli size; very rare, dense, finely crystalline, cognate basalt clasts; and a variety of shallow-water limestone clasts. Clasts 
Table 1. Thin-sections summary, Hole 878A.

\begin{tabular}{|c|c|c|c|c|c|c|c|c|c|c|c|}
\hline $\begin{array}{l}\text { Core, section, } \\
\text { interval (cm) }\end{array}$ & Lithology & $\begin{array}{c}\text { Total } \\
\text { porosity }\end{array}$ & Cement & Volcanics & $\begin{array}{l}\text { Ls. } \\
\text { clast }\end{array}$ & $\begin{array}{l}\text { Inorg. } \\
\text { calc. }\end{array}$ & Pellets & Peloids & Ooids & Oncoliths & Lithoclasts \\
\hline Upper carbonate se & ence: & & & & & & & & & & \\
\hline IR-CC, $0-4$ & Mudstone & 3 & 0 & 0 & 0 & 0 & 0 & 0 & 0 & 0 & 0 \\
\hline IR-CC, $26-28$ & Mudstone & 5 & 2 & 0 & 0 & 0 & 0 & 5 & 0 & 0 & 0 \\
\hline $2 \mathrm{R}-1,3-4$ & Packstone & 17 & 3 & 0 & 0 & 0 & 0 & 55 & 0 & 0 & 0 \\
\hline $2 \mathrm{R}-1,25-27$ & Grainstone & 15 & 7 & 0 & 0 & 0 & 0 & 45 & 0 & 0 & 0 \\
\hline $3 R-1,6-7$ & Grainstone & 22 & 5 & 0 & 0 & 0 & 0 & 35 & 0 & 0 & 0 \\
\hline $3 \mathrm{R}-1,59-61$ & Wackestone & 5 & 5 & 0 & 0 & 0 & 0 & 15 & 0 & 0 & 0 \\
\hline $4 \mathrm{R}-1,18-21$ & Packstone & 5 & 0 & 0 & 0 & 0 & 45 & 0 & 0 & 0 & 0 \\
\hline $4 \mathrm{R}-1,52-54$ & Packstone & 2 & 15 & 0 & 0 & 0 & 35 & 0 & 0 & 0 & 0 \\
\hline $7 \mathrm{R}-1,10-12$ & Wackestone & 7 & 1 & 0 & 0 & 0 & 0 & 10 & 0 & 0 & 0 \\
\hline $8 \mathrm{R}-1,33-36$ & Grainstone & 15 & 30 & 0 & 0 & 0 & 0 & 40 & 0 & 0 & 0 \\
\hline $9 \mathrm{R}-1,33-35$ & Packstone & 20 & 25 & 0 & 0 & 0 & 0 & 34 & 0 & 0 & 0 \\
\hline $10 \mathrm{R}-1,0-4$ & Packstone & 3 & 1 & 0 & 0 & 0 & 0 & 4 & 0 & 0 & 0 \\
\hline $11 \mathrm{R}-1,3-5$ & Packstone & 20 & 15 & 0 & 0 & 0 & 10 & 35 & 0 & 0 & 0 \\
\hline $12 \mathrm{R}-1,4-8$ & Mudstone & 0 & I & 0 & 0 & 0 & 0 & 3 & 0 & 0 & 0 \\
\hline 12R-I, $24-28$ & Mudstone & 7 & 3 & 0 & 0 & 0 & 0 & 0 & 0 & 0 & 0 \\
\hline $13 \mathrm{R}-1,22-29$ & Packstone & 20 & 20 & 0 & 0 & 0 & 1 & 30 & 0 & 0 & 0 \\
\hline $14 R-1,14-18$ & Mudstone & 3 & 0 & 0 & 0 & 0 & 0 & 10 & 0 & 0 & 0 \\
\hline $15 R-1,25-28$ & Mudstone & 2 & 0 & 0 & 0 & 0 & 0 & 5 & 0 & 0 & 0 \\
\hline $16 \mathrm{R}-1,12-18$ & Boundstone & 25 & 15 & 0 & 0 & 0 & 0 & 15 & 0 & 0 & 0 \\
\hline $18 \mathrm{R}-1.16-21$ & Wackestone & 5 & 1 & 0 & 0 & 0 & 0 & 25 & 0 & 0 & 0 \\
\hline $18 R-1,40-43$ & Grainstone & 17 & 25 & 0 & 0 & 0 & 0 & 15 & 0 & 0 & 0 \\
\hline $2 \mid R-1,0-4$ & Wackestone & 2 & 1 & 0 & 0 & 0 & 0 & 5 & 0 & 0 & 0 \\
\hline $22 \mathrm{R}-1,3-4$ & Grainstone & 32 & 2 & 0 & 0 & 0 & 0 & 41 & 0 & 0 & 0 \\
\hline $23 \mathrm{M}-1,13-16$ & Packstone & 17 & $i$ & 0 & 0 & 0 & 0 & 60 & 0 & 0 & 0 \\
\hline $26 \mathrm{M}-1,4-8$ & Wackestone & 10 & 1 & 0 & 0 & 0 & 0 & 0 & 0 & 0 & 0 \\
\hline $26 \mathrm{M}-1,8-12$ & Grainstone & 10 & 35 & 0 & 0 & 0 & 0 & 0 & 0 & 0 & 0 \\
\hline $26 \mathrm{M}-1,31-34$ & Rudstone & 3 & 42 & 0 & 0 & 0 & 0 & 8 & 0 & 0 & 0 \\
\hline $30 \mathrm{M}-1,29-31$ & Rudstone & 25 & 3 & 0 & 0 & 0 & 0 & 23 & 0 & 20 & 1 \\
\hline $31 \mathrm{M}-1,22-26$ & Packstone & 25 & 5 & 0 & 0 & 0 & 0 & 20 & 0 & 0 & 0 \\
\hline $33 \mathrm{M}-1,11-14$ & Boundstone & 30 & 10 & 0 & 0 & 0 & 0 & 0 & 0 & 4 & 0 \\
\hline $36 \mathrm{M}-1,57-60$ & Packstone & 7 & 3 & 0 & 0 & 0 & 0 & 50 & 0 & 2 & 0 \\
\hline $37 \mathrm{M}-1,13-19$ & Grainstone & 40 & 7 & 0 & 0 & 0 & 0 & 40 & 0 & 2 & 0 \\
\hline $37 \mathrm{M}-1,32-35$ & Rudstone & 45 & 2 & 0 & 0 & 0 & 0 & 5 & 0 & 15 & 0 \\
\hline $38 \mathrm{M}-1,0-6$ & Grainstone & 30 & i & 0 & 0 & 0 & 0 & 40 & 0 & 0 & 0 \\
\hline $39 \mathrm{M}-1,4-13$ & Grainstone & 25 & i & 0 & 0 & 0 & 0 & 60 & 0 & i & 0 \\
\hline $39 \mathrm{M}-1,48-51$ & Grainstone & 30 & 15 & 0 & 0 & 0 & 0 & 25 & 0 & 0 & 0 \\
\hline $41 \mathrm{M}-1,4-8$ & Grainstone & 7 & 3 & 0 & 0 & 0 & 0 & 65 & 0 & 0 & 0 \\
\hline $42 \mathrm{M}-1,11-15$ & Packstone & 3 & I & 0 & 0 & 0 & 0 & 5 & 0 & 0 & 0 \\
\hline $43 \mathrm{M}-1,18-21$ & Rudstone & 7 & 2 & 0 & 0 & 0 & 0 & 20 & 0 & 0 & 0 \\
\hline $43 \mathrm{M}-1,33-36$ & Wackestone & 10 & i & 0 & 0 & 0 & 0 & 21 & 0 & 0 & 0 \\
\hline $42 \mathrm{M}-1,26-32$ & Wackestone & 10 & 2 & 0 & 0 & 0 & 0 & 25 & 0 & 0 & 0 \\
\hline Pyroclastic unit: & & & & & & & & & & & \\
\hline $44 \mathrm{M}-2,12-15$ & Breccia & 1 & 20 & 30 & 33 & 0 & 0 & 0 & 0.1 & 0 & 0 \\
\hline $44 \mathrm{M}-2,114-118$ & Breccia & 0 & 19 & 45 & 10 & 0 & 0 & 20 & 0 & 0 & 9 \\
\hline $45 \mathrm{M}-2,89-93$ & Breccia & 0 & 30 & 40 & 24 & 0 & 0 & 2 & 2 & 0 & 0 \\
\hline $46 \mathrm{M}-2,22-23$ & Breccia & 0 & 0 & 30 & 5 & 0 & 0 & 3 & 3 & i & 0 \\
\hline $48 \mathrm{R}-1,61-64$ & Breccia & 0 & 0 & 40 & 5 & 0 & 0 & 10 & 3 & 0.1 & 0 \\
\hline $49 \mathrm{R}-2,80-84$ & Breccia & 0 & 1 & 30 & 5 & 0 & 0 & 10 & 3 & 0 & 0 \\
\hline 50R-2, 75-79 & Breccia & 0 & 0 & 25 & 2 & 0 & 0 & 15 & 3 & 0 & 0 \\
\hline 50R $-1,32-34$ & Breccia & 0 & 0 & 15 & 5 & 0 & 0 & 30 & 5 & 0 & 0 \\
\hline $50 \mathrm{R}-2,116-119$ & Breccia & 0 & 0 & 30 & 10 & 0 & 0 & 15 & 2 & 0 & 0 \\
\hline $51 R-5,4-7$ & Breccia & 5 & 5 & 15 & 0 & 0 & 0 & 15 & 2 & 0 & 0 \\
\hline $51 \mathrm{R}-5,88-92$ & Breccia & 0 & 0 & 35 & 5 & 0 & 0 & 40 & 5 & 0 & 0 \\
\hline $52 \mathrm{R}-1,136-138$ & Breccia & 0 & 0 & 40 & 3 & 0 & 0 & 30 & 2 & 0 & 0 \\
\hline $53 \mathrm{R}-3,140-141$ & Breccia & 0 & 0 & 20 & 10 & 0 & 0 & 41 & 3 & 0 & 0 \\
\hline $53 \mathrm{R}-4,78-80$ & Breccia & 0 & 0 & 30 & 30 & 0 & 0 & 25 & 5 & 0 & 0 \\
\hline $54 \mathrm{R}-2,0-3$ & Breccia & 0 & 30 & 5 & 25 & 0 & 0 & 30 & 0 & 0 & 0 \\
\hline $54 R-5,98-102$ & Breccia & 0 & 0 & 30 & 10 & 0 & 0 & 30 & 2 & 0 & 0 \\
\hline $54 \mathrm{R}-5,128-133$ & Breccia & 0 & 0 & 30 & 20 & 0 & 0 & 25 & 3 & 0 & 0 \\
\hline $56 \mathrm{R}-2,66-68$ & Breccia & 0 & 0 & 25 & 25 & 0 & 0 & 30 & 0.1 & 0 & 0 \\
\hline $55 \mathrm{R}-2,26-32$ & Breccia & 6 & 4 & 35 & 5 & 0 & 0 & 6 & 2 & 0 & 0 \\
\hline $45 \mathrm{M}-1,105-109$ & Wackestone & 3 & 22 & 0 & 0 & 0 & 0 & 30 & 0 & 0 & 0 \\
\hline $45 \mathrm{M}-3,123-125$ & Wackestone & 5 & 20 & 0 & 0 & 0 & 0 & 10 & 0 & 0 & 0 \\
\hline $47 \mathrm{R}-2,30-32$ & Rudstone & 0 & 40 & 0 & 0 & 0 & 0 & 20 & 5 & 0 & 0 \\
\hline $48 \mathrm{R}-1,36-38$ & Wackestone & 0 & 15 & 0 & 0 & 0 & 0 & 0 & 20 & 0 & 0 \\
\hline $51 \mathrm{R}-2,5-10$ & Packstone & 1 & is & 0 & 0 & 0 & 4 & 45 & 0 & 0 & 0 \\
\hline $53 \mathrm{R}-3,59-6 \mathrm{I}$ & Packstone & 0 & 3 & 0 & 0 & 0 & 0 & 40 & 0 & 10 & 0 \\
\hline $53 \mathrm{R}-4,54-55$ & Wackestone & 0 & 3 & 0 & 0 & 0 & 0 & 25 & 0 & 0 & 0 \\
\hline $55 R-2,42-45$ & Wackestone & 0 & 5 & 0 & 0 & 0 & 0 & 30 & 0 & 0 & 0 \\
\hline $55 \mathrm{R}-3,46-49$ & Wackestone & 0 & 0 & 0 & 0 & 0 & 0 & 0 & 0.1 & 0 & 0 \\
\hline $55 \mathrm{R}-6,106-107$ & Wackestone & 30 & 0 & 0 & 0 & 0 & 0 & 20 & 0 & 0 & 0 \\
\hline $56 \mathrm{R}-3,135-137$ & Breccia & 0 & 20 & 30 & 20 & 0 & 0 & 15 & 0 & 0 & 0 \\
\hline $57 \mathrm{R}-1,53-57$ & Breccia & 0 & 0 & 40 & 5 & 0 & 0 & 20 & 5 & 0 & 0 \\
\hline $58 \mathrm{R}-2,11-15$ & Breccia & 0 & 9 & 20 & 35 & 0 & 0 & 15 & 0 & 0 & 0 \\
\hline $58 \mathrm{R}-3,90-94$ & Breccia & 3 & 0 & 20 & 5 & 0 & 0 & 26 & 0 & 0 & 0 \\
\hline $58 \mathrm{R}-7,47-49$ & Breccia & 3 & 7 & 15 & 60 & 0 & 0 & 9 & 0 & 0 & 0 \\
\hline $59 \mathrm{R}-6,109-114$ & Breccia & i & 3 & 25 & 20 & 0 & 0 & 10 & 0 & 10 & 0 \\
\hline $59 \mathrm{R}-2,19-20$ & Breccia & 2 & 3 & 25 & 15 & 0 & 0 & 17 & 2 & 0 & 0 \\
\hline $59 \mathrm{R}-3,123-125$ & Breccia & 0 & 0 & 25 & 25 & 0 & 3 & 15 & I & 0 & 0 \\
\hline $59 R-5,100-103$ & Breccia & 5 & 3 & 7 & 80 & 0 & 0 & 5 & 0 & 0 & 0 \\
\hline $59 \mathrm{R}-7,27-28$ & Breccia & 0 & 0 & 35 & 5 & 0 & 0 & 19 & 3 & 0 & 0 \\
\hline $60 \mathrm{R}-1.129-132$ & Breccia & 2 & 0 & 15 & 50 & 0 & 0 & 10 & 7 & 0 & 0 \\
\hline $60 \mathrm{R}-2,83-86$ & Breccia & 0 & 6 & 30 & 10 & 0 & 0 & 27 & 0 & 0 & 0 \\
\hline $60 \mathrm{R}-3,36-39$ & Breccia & 0 & 3 & 10 & 65 & 0 & 0 & 14 & 1 & 0 & 0 \\
\hline $60 \mathrm{R}-5,50-53$ & Breccia & 5 & 0 & 15 & 5 & 0 & 0 & 30 & 3 & 0 & 0 \\
\hline
\end{tabular}


Table 1 (continued).

\begin{tabular}{|c|c|c|c|c|c|c|c|c|c|c|c|}
\hline $\begin{array}{l}\text { Core, section, } \\
\text { interval }(\mathrm{cm})\end{array}$ & Lithology & $\begin{array}{l}\text { Benthic } \\
\text { forams. }\end{array}$ & Ostracods & Echinoderms & $\begin{array}{l}\text { Calc. } \\
\text { sponge }\end{array}$ & Coral & Gastropods & Rudist & $\begin{array}{c}\text { Other } \\
\text { bivalve }\end{array}$ & $\begin{array}{l}\text { Red } \\
\text { algae }\end{array}$ & $\begin{array}{l}\text { Green } \\
\text { algae }\end{array}$ \\
\hline Upper carbonate se & nce: & & & & & & & & & & \\
\hline IR-CC, $0-4$ & Mudstone & 0 & 0 & 1 & 0 & 0 & 0 & 0 & 1 & 0 & 0 \\
\hline IR-CC, $26-28$ & Mudstone & 1 & 0 & 0 & 0 & 0 & 0 & 0 & i & 0 & 0 \\
\hline $2 \mathrm{R}-1,3-4$ & Packstone & 1 & 0 & 1 & 0 & 0 & 0 & 0 & 3 & 0 & 0 \\
\hline $2 \mathrm{R}-1,25-27$ & Grainstone & 15 & 0 & 3 & 0 & 0 & 0 & 0 & 0 & 0 & 5 \\
\hline $3 \mathrm{R}-1,6-7$ & Grainstone & 5 & 0 & 3 & 0 & 0 & 0 & 0 & 15 & 0 & 0 \\
\hline $3 R-1,59-61$ & Wackestone & 3 & 0 & 0.1 & 0 & 0 & 0 & 0 & 5 & 0 & 0 \\
\hline $4 \mathrm{R}-1,18-21$ & Packstone & 4 & 0 & 0.1 & 0.1 & 0 & I & 0 & 0.1 & 0 & 2 \\
\hline $4 \mathrm{R}-1,52-54$ & Packstone & 15 & 0 & 0 & 0 & 0 & 0 & 0 & 5 & 0 & 1 \\
\hline $7 \mathrm{R}-1,10-12$ & Wackestone & 0 & 0 & 0 & 0 & 0 & 0 & 0 & 3 & 0 & 5 \\
\hline $8 \mathrm{R}-1,33-36$ & Grainstone & 3 & 0 & 0 & 0 & 0 & 0 & 0 & 12 & 0 & 0 \\
\hline $9 R-1,33-35$ & Packstone & 2 & 0 & 0 & 0 & 0 & 0 & 0 & 2 & 2 & 0 \\
\hline $10 \mathrm{R}-1,0-4$ & Packstone & 2 & 0 & 0 & 0 & 0 & 0 & 0 & 2 & 0 & 0 \\
\hline IIR-1.3-5 & Packstone & 2 & 0 & 0 & 0 & 0 & 0 & 0 & 3 & 0 & 0 \\
\hline $12 \mathrm{R}-1,4-8$ & Mudstone & 0 & 2 & 0 & 0 & 0 & 0 & 0 & 0 & 0 & 0 \\
\hline $12 \mathrm{R}-1,24-28$ & Mudstone & 0 & 0 & 0 & 0 & 0 & 0 & 0 & 3 & 0 & 0 \\
\hline $13 \mathrm{R}-1.22-29$ & Packstone & 4 & 0 & 0 & 0 & 0 & 0 & 0 & 1 & 0 & 15 \\
\hline $14 \mathrm{R}-1,14-18$ & Mudstone & 1 & 0 & 0 & 0 & 0 & 0 & 0 & 0 & 0 & 0 \\
\hline $15 \mathrm{R}-1,25-28$ & Mudstone & 0 & 0 & 0 & 0 & 0 & 0 & 0 & 1 & 0 & 2 \\
\hline $16 \mathrm{R}-1,12-18$ & Boundstone & 0 & 0 & 0 & 38 & 0 & 0 & 0 & 0 & 0 & 0 \\
\hline $18 \mathrm{R}-1,16-21$ & Wackestone & 1 & 2 & 1 & 0 & 0 & 1 & 0 & 1 & 0.1 & 1 \\
\hline $18 \mathrm{R}-1,40-43$ & Grainstone & 0.1 & 0 & 0.1 & 0 & 0 & 2 & 0 & 10 & 0 & 26 \\
\hline $21 \mathrm{R}-1,0-4$ & Wackestone & 0 & 3 & 0 & 0 & 0 & 0 & 0 & 0 & 0 & 0 \\
\hline $22 \mathrm{R}-1,3-4$ & Grainstone & 0 & 0 & 0 & 0 & 0 & 0 & 0 & 0 & 0 & 0 \\
\hline $23 \mathrm{M}-1,13-16$ & Packstone & 2 & 0 & 0 & 0 & 0 & 3 & 0 & 0.1 & 0 & 0 \\
\hline $26 \mathrm{M}-1,4-8$ & Wackestone & 6 & 0 & 0 & 0 & 0 & 0 & 0 & 0 & 0 & 0 \\
\hline $26 \mathrm{M}-1,8-12$ & Grainstone & 20 & 0 & 5 & 0 & 0 & 0 & 0 & 30 & 0 & 0 \\
\hline $26 \mathrm{M}-1,31-34$ & Rudstone & 0 & 0 & 0 & 0 & 0 & 0 & 0 & 25 & 0 & 2 \\
\hline $30 \mathrm{M}-1,29-31$ & Rudstone & 5 & 0 & 3 & 0 & 0 & 0 & 0 & 17 & 0 & 0 \\
\hline $31 \mathrm{M}-1,22-26$ & Packstone & 10 & 0 & 5 & 0 & 0 & 0 & 0 & 20 & 0 & 0 \\
\hline $33 \mathrm{M}-1.11-14$ & Boundstone & 3 & 0 & 0 & 4 & 0 & 0 & 20 & 0 & 0 & 0 \\
\hline $36 \mathrm{M}-1.57-60$ & Packstone & 4 & 0 & 4 & 0 & 0 & 0 & 0 & 5 & 0 & 0 \\
\hline $37 \mathrm{M}-1,13-19$ & Grainstone & 1 & 0 & 3 & 0 & 0 & 0 & 0 & 7 & 0 & 0.1 \\
\hline $37 \mathrm{M}-1,32-35$ & Rudstone & 15 & 0 & 5 & 0 & 0 & 0 & 0 & 7 & 0 & 1 \\
\hline $38 \mathrm{M}-1,0-6$ & Grainstone & 0 & 0 & 3 & 0 & 0 & 0 & 0 & 0 & 0 & 0 \\
\hline $39 \mathrm{M}-1,4-13$ & Grainstone & 1 & 0 & 2 & 0 & 0 & 0 & 0 & 10 & 0 & 0 \\
\hline $39 \mathrm{M}-1.48-51$ & Grainstone & 0 & 0 & 5 & 0 & 0 & 0 & 0 & 20 & 0 & 0 \\
\hline $41 \mathrm{M}-1,4-8$ & Grainstone & 7 & 0 & 3 & 0 & 0 & 0 & 0 & 5 & 0 & 0 \\
\hline $42 \mathrm{M}-1,11-15$ & Packstone & 1 & 0 & 0 & 0 & 0 & 0 & 0 & 2 & 0 & 0 \\
\hline $43 \mathrm{M}-1,18-21$ & Rudstone & 2 & 0 & 0 & 0 & 0 & 0 & 0 & 2 & 0 & 0 \\
\hline $43 \mathrm{M}-1,33-36$ & Wackestone & 2 & 0 & 0 & 0 & 0 & 0 & 0 & 0 & 0 & 9 \\
\hline $42 \mathrm{M}-1,26-32$ & Wackestone & 35 & 0 & 0 & 0 & 0 & 1 & 0 & 2 & 0 & 0 \\
\hline Pyroclastic unit: & & & & & & & & & & & \\
\hline $44 \mathrm{M}-2,12-15$ & Breccia & 0 & 0 & 0 & 0 & 0 & 0 & 0 & 0.1 & 0 & 0 \\
\hline $44 \mathrm{M}-2,114-118$ & Breccia & 0 & 0 & 0 & 0 & 0 & 0 & 0 & 1 & 0 & 0 \\
\hline $45 \mathrm{M}-2,89-93$ & Breccia & 0 & 0 & 0 & 0 & 0 & 0 & 0 & 0 & 0 & 0 \\
\hline $46 \mathrm{M}-2,22-23$ & Breccia & 0 & 0 & 0 & 0 & 0 & 0 & 0 & 1 & 0 & 0 \\
\hline $48 \mathrm{R}-1,61-64$ & Breccia & 0 & 0 & 0.1 & 1 & 0 & 0 & 0 & 1 & 0 & 0 \\
\hline $49 \mathrm{R}-2,80-84$ & Breccia & 0 & 0 & 0 & 0 & 0 & 0 & 0 & 0 & 0 & 0 \\
\hline $50 \mathrm{R}-2,75-79$ & Breccia & 0 & 0 & 0.1 & 0 & 0 & 0 & 0 & 0 & 0 & 0 \\
\hline $50 \mathrm{R}-1,32-34$ & Breccia & 0 & 0 & 0 & 0 & 0 & 0 & 0.1 & 0 & 0 & 0 \\
\hline $50 \mathrm{R}-2,116-119$ & Breccia & 0 & 0 & 0 & 0 & 0 & 0 & 0 & 0 & 0 & 0 \\
\hline $5 I R-5,4-7$ & Breccia & 2 & 0 & 0 & 0 & 0 & 0 & 0 & 15 & 0 & 0 \\
\hline $51 \mathrm{R}-5,88-92$ & Breccia & 0 & 0 & 0 & 0 & 0 & 0 & 0 & 1 & 0 & 0 \\
\hline $52 \mathrm{R}-1,136-138$ & Breccia & 0 & 0 & 0 & 0 & 0 & 0 & 1 & 1 & 0 & 0 \\
\hline $53 R-3,140-141$ & Breccia & 0 & 0 & 0 & 0 & 0 & 0 & 0 & 0 & 0 & 0 \\
\hline $53 \mathrm{R}-4,78-80$ & Breccia & 0 & 0 & 0 & 0 & 0 & 0.1 & 0 & 0 & 0 & 0.1 \\
\hline $54 \mathrm{R}-2,0-3$ & Breccia & 0 & 0 & 0 & 0 & 0 & 0 & 0 & 1 & 0 & 0 \\
\hline $54 \mathrm{R}-5,98-102$ & Breccia & 0 & 0 & 0 & 0 & 0 & 0 & 0 & 2 & 0 & 0 \\
\hline $54 \mathrm{R}-5,128-133$ & Breccia & 0 & 0 & 0 & 0 & 0 & 0 & 1 & 0 & 0 & 0 \\
\hline $56 \mathrm{R}-2,66-68$ & Breccia & 0 & 0 & 0 & 0 & 0 & 0 & 0 & 0 & 0 & 0 \\
\hline $55 \mathrm{R}-2,26-32$ & Breccia & 0 & 0 & 0 & 0 & 0 & 0 & 0 & 2 & 0 & 0 \\
\hline $45 \mathrm{M}-1,105-109$ & Wackestone & 0 & 0 & 0 & 0 & 0 & 0 & 0 & 0 & 0 & 0 \\
\hline $45 \mathrm{M}-3,123-125$ & Wackestone & 35 & 1 & 0 & 0 & 0 & 0 & 0 & 2 & 0 & 2 \\
\hline $47 \mathrm{R}-2,30-32$ & Rudstone & 0 & 0 & 1 & 1 & 1 & 0 & 10 & 1 & 0 & 10 \\
\hline $48 \mathrm{R}-\mathrm{I}, 36-38$ & Wackestone & 0 & 0.1 & 0 & 0 & 0 & 0 & 0 & $i$ & 0 & 0 \\
\hline $51 R-2,5-10$ & Packstone & 0 & 0 & 0 & 0 & 0 & 0 & 0 & 0 & 0 & 0 \\
\hline $53 R-3,59-61$ & Packstone & 0 & 0.1 & 0 & 0 & 0 & 0 & 1 & 0 & 0 & 0 \\
\hline $53 \mathrm{R}-4,54-55$ & Wackestone & 0 & 0.1 & 0 & 0 & 0 & 0 & 0 & 0 & 0 & 0 \\
\hline $55 R-2,42-45$ & Wackestone & 0 & 0.1 & 0 & 0 & 0 & 0 & 0 & 0 & 0 & 0 \\
\hline $55 \mathrm{R}-3,46-49$ & Wackestone & 0 & 0 & 0 & 0 & 0 & 1 & 0 & 0 & 0 & 0 \\
\hline $55 R-6,106-107$ & Wackestone & 0 & 0.1 & 0 & 0 & 0 & 0 & 0 & 0 & 0 & 0 \\
\hline $56 \mathrm{R}-3,135-137$ & Breccia & 0 & 0 & 0 & 0 & 0 & 0 & 0 & 0 & 0 & 0 \\
\hline $57 \mathrm{R}-1,53-57$ & Breccia & 0 & 0 & 0 & 0 & 0 & 0 & 0 & 0 & 0 & 0 \\
\hline $58 \mathrm{R}-2,11-15$ & Breccia & 1 & 0 & 0 & 0 & 0 & 0 & 0 & 0 & 0 & 0 \\
\hline $58 \mathrm{R}-3,90-94$ & Breccia & 2 & 0 & 0 & 0 & 0 & 0 & 0 & 1 & 0 & 1 \\
\hline $58 \mathrm{R}-7,47-49$ & Breccia & 1 & 0 & 0 & 0 & 0 & 0 & 0 & 0 & 0 & 0 \\
\hline $59 \mathrm{R}-6,109-114$ & Breccia & 0 & 0 & 0 & 0 & 0 & 0 & 0 & 0 & 0 & 1 \\
\hline $59 \mathrm{R}-2,19-20$ & Breccia & 0 & 0 & 0 & 0 & 0 & 0 & 0 & 1 & 0 & 0 \\
\hline $59 \mathrm{R}-3,123-125$ & Breccia & 0 & 0 & 0 & 0 & 0 & 0 & 0 & 0 & 0 & 1 \\
\hline $59 \mathrm{R}-5,100-103$ & Breccia & 0 & 0 & 0 & 0 & 0 & 0 & 0 & 0 & 0 & 0 \\
\hline $59 \mathrm{R}-7,27-28$ & Breccia & 0 & 0 & 0 & 0 & 0 & 0 & 0 & 3 & 0 & 0 \\
\hline $60 \mathrm{R}-1,129-132$ & Breccia & 5 & 0 & 0 & 0 & 0 & 0 & 0 & 1 & 0 & 0 \\
\hline $60 \mathrm{R}-2,83-86$ & Breccia & 0 & 0 & 0 & 0 & 0 & 0 & 0 & 0 & 0 & 0 \\
\hline $60 \mathrm{R}-3,36-39$ & Breccia & 0 & 0 & 0 & 0 & 0 & 0 & 0 & 2 & 0 & 0 \\
\hline $60 R-5,50-53$ & Breccia & 0 & 0 & 0 & 0 & 0 & 0 & 0 & 0 & 0 & 0 \\
\hline
\end{tabular}


Table 1 (continued).

\begin{tabular}{|c|c|c|c|c|c|c|c|c|c|c|c|c|c|c|}
\hline $\begin{array}{l}\text { Core, section. } \\
\text { interval }(\mathrm{cm})\end{array}$ & Lithology & $\begin{array}{c}\text { Total } \\
\text { porosity }\end{array}$ & Cement & Volcanics & $\begin{array}{l}\text { Ls. } \\
\text { clast }\end{array}$ & $\begin{array}{l}\text { Inorg. } \\
\text { calc. }\end{array}$ & Pellets & Peloids & Ooids & Oncoliths & Lithoclasts & Intraclasts & Micrite & Forams. \\
\hline $60 \mathrm{R}-6,13-16$ & Breccia & 0 & 1 & 10 & 13 & 0 & 0 & 40 & 5 & 0 & 0 & 0 & 30 & 0 \\
\hline $6 \mathrm{IR}-2,75-78$ & Breccia & 5 & 2 & 5 & 30 & 0 & 0 & 20 & 3 & 0 & 0 & 0 & 35 & 0 \\
\hline $61 \mathrm{R}-4,83-86$ & Breccia & 8 & 2 & 10 & 60 & 0 & 0 & 15 & 0 & 0 & 0 & 0 & 5 & 0 \\
\hline $62 R-2,145-150$ & Breccia & 3 & 2 & 7 & 2 & 0 & 0 & 30 & 0 & 0 & 0 & 0 & 52 & 0 \\
\hline $65 \mathrm{R}-5,84-86$ & Breccia & 7 & 0 & 13 & $1 \overline{3}$ & 0 & 0 & 25 & 2 & 0 & 0 & 0 & 35 & 0 \\
\hline \multicolumn{15}{|c|}{ Lower carbonate sequence: } \\
\hline $65 R-2,11-14$ & Packstone & 0 & 18 & 0 & 0 & 0 & 0 & 35 & 0 & 0 & 0 & 2 & 15 & 20 \\
\hline $65 \mathrm{R}-6,35-37$ & Grainstone & 25 & 6 & 0 & 0 & 0 & 0 & 5 & 10 & 20 & 0 & 0 & 0 & 0 \\
\hline $65 \mathrm{R}-6,41-45$ & Grainstone & 18 & 3 & 0 & 0 & 0 & 0 & 0 & 20 & 0 & 0 & 10 & 60 & 0 \\
\hline $66 \mathrm{R}-1,0-5$ & Grainstone & 25 & 3 & 0 & 0 & 0 & 0 & 15 & 5 & 0 & 0 & 2 & 0 & 0 \\
\hline $66 \mathrm{R}-1,10-15$ & Grainstone & 22 & I & 0 & 0 & 0 & 0 & 15 & 40 & 0 & 0 & 0 & 0 & 0 \\
\hline $67 \mathrm{R}-1,7-11$ & Grainstone & 25 & i & 0 & 0 & 0 & 0 & 30 & 3 & i & 0 & 0.1 & 0 & 0 \\
\hline $67 \mathrm{R}-1,65-69$ & Grainstone & 25 & 3 & 0 & 0 & 0 & 20 & 30 & 15 & 0 & 0 & 0 & 0 & 0 \\
\hline $68 \mathrm{R}-1,11-16$ & Packstone & 2 & 5 & 0 & 0 & 0 & 0 & 68 & 0 & 0 & 0 & 0 & 20 & 0 \\
\hline $69 \mathrm{R}-1,20-23$ & Packstone & 5 & 0 & 0 & 0 & 0 & 0 & 50 & 0.1 & 0 & 0 & 0 & 25 & 15 \\
\hline $70 \mathrm{R}-1,11-15$ & Wackestone & 19 & I & 0 & 0 & 0 & 0 & is & 0 & 0 & 0 & 0 & 55 & 0 \\
\hline $70 \mathrm{R}-1,24-29$ & Packstone & 10 & 0 & 0 & 0 & 0 & 0 & 70 & 0.1 & 0 & 0 & 0 & 0 & 0 \\
\hline $7 \mathrm{IR}-1,91-94$ & Grainstone & 25 & 4 & 0 & 0 & 0 & 0 & 40 & 5 & 0,1 & & 5 & 0 & 0 \\
\hline $71 \mathrm{R}-1,100-103$ & Grainstone & 20 & 8 & 0 & 0 & 0 & 0 & 30 & 2 & 0 & 0 & 18 & 0 & 0 \\
\hline $72 \mathrm{R}-1,6-10$ & Packstone & 15 & 5 & 0 & 0 & 0 & 0 & 35 & 2 & 1 & 0 & 19 & 13 & 0 \\
\hline $72 \mathrm{R}-1,18-22$ & Grainstone & 30 & 2 & 0 & 0 & 0 & 0 & 30 & 30 & 0 & 0 & 0.1 & 0 & 0 \\
\hline $73 \mathrm{R}-1,37-41$ & Packstone & 25 & 5 & 0 & 0 & 0 & 0 & 14 & 0 & 3 & 0 & 22 & 0 & 0 \\
\hline $73 \mathrm{R}-1.42-45$ & Grainstone & 20 & 4 & 0 & 0 & 0 & 0 & 15 & 2 & 3 & & 0.1 & 0 & 0 \\
\hline $74 \mathrm{R}-1,36-42$ & Packstone & 3 & 0 & 0 & 0 & 0 & 0 & 50 & 0 & 0 & 0 & 0 & 30 & 0 \\
\hline $75 \mathrm{R}-1.0-4$ & Wackestone & 15 & i & 0 & 0 & 0 & 0 & 30 & 0 & 0 & 0 & 0 & 45 & 0 \\
\hline $75 \mathrm{R}-1,5-10$ & Grainstone & 8 & 2 & 0 & 0 & 0 & 0 & 70 & 0 & 0 & 0 & i & 0 & 0 \\
\hline $75 \mathrm{R}-1.38-41$ & Packstone & 2 & $i$ & 0 & 0 & 0 & 0 & 60 & 0 & 0.1 & 0 & 0 & 30 & 0 \\
\hline $75 R-1,141-143$ & Wackestone & 8 & 3 & 0 & 0 & 15 & 0 & 17 & 0 & 0 & 0 & 0 & 41 & 0 \\
\hline $75 \mathrm{R}-2,0-4$ & Wackestone & 5 & $i$ & 0 & 0 & 10 & 0 & 12 & 0 & 0 & 0 & 0 & 42 & 0 \\
\hline $76 \mathrm{R}-1,78-83$ & Grainstone & 30 & 7 & 0 & 0 & 0 & 0 & 10 & 0 & 1 & 0 & I & 0 & 0 \\
\hline $76 \mathrm{R}-1,12-14$ & Grainstone & 35 & 6 & 0 & 0 & 0 & 0 & 35 & 0 & 0 & 0 & 13 & 0 & 0 \\
\hline $77 \mathrm{R}-1.35-38$ & Grainstone & 7 & 0 & 0 & 0 & 30 & 0 & 0.1 & 0 & 0 & 0 & 3 & 7 & 3 \\
\hline $77 \mathrm{R}-1,48-52$ & Packstone & 35 & 0 & 0 & 0 & 0 & 0 & 22 & 0 & 0 & 0 & 0 & 2 & 0 \\
\hline $78 \mathrm{R}-1,4-6$ & Grainstone & 35 & 3 & 0 & 0 & 0 & 0 & 4 & 5 & 10 & 0 & 0 & 0 & 0 \\
\hline $78 \mathrm{R}-1,16-20$ & Floatstone & 10 & 30 & 0 & 0 & 0 & 0 & 2 & 1 & 2 & 0 & 0 & 0 & 0 \\
\hline $78 \mathrm{R}-\mathrm{I}, 49-52$ & Grainstone & 3 & 3 & 0 & 0 & 0 & 40 & 0 & 0 & 0 & 0 & 0 & 40 & 10 \\
\hline
\end{tabular}

Note: Ls. clast $=$ limestone, Inorg, calc. $=$ inorganic calcium, Forams.$=$ foraminifers, and Calc, sponge $=$ calcareous sponges

are deposited in a very fine-grained limestone matrix. The oxidized top of the breccia pile indicates that the surface was subaerially exposed, or exposed to percolated oxygenated groundwater. The fragmentation of the lower carbonate sequence at the vent area, by the volcanic eruption, resulted in mixing and incorporation of limestone clasts into pyroclastic deposit.

A study of the foraminifers and nannofossils (Premoli Silva, Haggerty, Rack, et al., 1993) and the results of reexamining the foraminifers (Fig. 5; Arnaud Vanneau, this volume) indicate that the lower carbonate sequence is early Aptian (younger than Magnetic Anomaly $\mathrm{MO}$ ), the polymictic breccia is late Aptian, and the upper carbonate sequence is late Aptian to late Albian. The biostratigraphic age of the volcanic breccia was derived from the age of limestone clasts incorporated into the breccia during the volcanic explosion. Thus, the clasts are of pre-eruption age and do not reflect the age of the volcanic event. The presence of orbitolinids in some of the clasts suggests a Gargasian (late Aptian) age for some of the clasts within the breccia. Because no clasts younger than late Aptian are incorporated within the breccia, the volcanic event must have occurred during the late Aptian.

During the shipboard description of cores, both carbonate sequences were subdivided into nine smaller lithologic subunits and seven paleoecological assemblage zones (Fig. 4; Premoli Silva, Haggerty, Rack, et al., 1993). The lithologic boundaries established from the wireline logs are closer to paleoecological zone boundaries (Fig. 5) than they are to the lithologic unit boundaries established from the core descriptions.

\section{FACIES}

Lithofacies identification based on interpretations of the wireline logs and a comparison of the logs with the core and thin-section descriptions (Table 1) indicate that, even though a high frequency of lithologic change is indicated by the cores (Premoli Silva, Haggerty, Rack, et al., 1993), only a few major lithofacies construct the carbonate sequence. According to such evidence, the dominant lithofacies are grainstone and packstone, wackestone is subordinate, and carbonate mudstone is rare (Fig. 6). Thin layers of boundstone and/or their debris are rare and are occasionally present as pebbly/rubble beds. The interpreted facies based upon wireline log analyses compares reasonably, but not completely, to the lithofacies interpreted from studies of the core; core recovery was only $6.5 \%$ in the lower platform and $2.3 \%$ at the upper platform. Despite the high variability in both biota and carbonate constituents within individual facies, the principal limestone constituents are similar throughout the carbonate strata, although the quantitative content of individual components may vary. No clastic rocks are present within the carbonate sequence. Geochemical analyses of limestones show that the $\mathrm{CaCO}_{3}$ content ranges from $98 \%$ to $99 \%$ (Premoli Silva, Haggerty, Rack, et al., 1993).

Extensive literature is available on the anatomy, facies, and biota within different depositional systems of modern reefs and atolls. A large volume of publications on this theme and additional references can be found in the journal Coral Reefs (Springer Verlag). Some of the publications have been summarized by Jones and Endean (1973), Barnes (1983), Davies and Montaggioni (1985), Montaggioni et al. (1985), Veron (1986), and others. As mentioned previously, these data are augmented by the authors' own comparative studies of modern atolls and reefs in the Pacific, including those of the Marshall Islands, Tahiti, Cook Islands, the Great Barrier Reef of Australia, and the fringing reefs of Papua New Guinea, as well as reefs of the Caribbean and extensive studies of Mesozoic carbonate platforms and reefs of the circum-North Atlantic.

The principal difference between modern reefs and atolls and mid-Cretaceous carbonate buildups is that scleractinian corals, which underwent a period of great diversity during the Late Jurassic, are little known from the Early Cretaceous, whereas at the end of the Cretaceous both hermatypic and ahermatypic corals flourished much as they do today (Veron, 1986). In the Early Cretaceous, rudists coexisted with corals in reef systems, each occupying separate habitats (Scott, 1988). Corals, algae, and stromatoporoids built the reef frame below the normal wave base, and rudists composed the com- 
Table 1 (continued).

\begin{tabular}{|c|c|c|c|c|c|c|c|c|c|c|c|c|}
\hline $\begin{array}{l}\text { Core, section, } \\
\text { interval }(\mathrm{cm})\end{array}$ & Lithology & $\begin{array}{l}\text { Benthic } \\
\text { forams. }\end{array}$ & Ostracods & Echinoderms & $\begin{array}{l}\text { Calc. } \\
\text { sponge }\end{array}$ & Coral & Gastropods & Rudist & $\begin{array}{c}\text { Other } \\
\text { bivalve }\end{array}$ & $\begin{array}{l}\text { Red } \\
\text { algae }\end{array}$ & $\begin{array}{l}\text { Green } \\
\text { algae }\end{array}$ & Others \\
\hline $60 \mathrm{R}-6,13-16$ & Breccia & 1 & 0 & 0 & 0 & 0 & 0 & 0 & 0 & 0 & 0 & 0 \\
\hline $61 \mathrm{R}-2,75-78$ & Breccia & 0 & 0 & 0 & 0 & 0 & 0 & 0 & 0 & 0 & 0 & 0 \\
\hline $61 R-4,83-86$ & Breccia & 0 & 0 & 0 & 0 & 0 & 0 & 0 & 0 & 0 & 0 & 0 \\
\hline $62 \mathrm{R}-2,145-150$ & Breccia & 0 & 0 & 0 & 0 & 0 & 0 & 0 & 3 & 0 & 0 & 1 \\
\hline $65 \mathrm{R}-5,84-86$ & Breccia & 0 & 0 & 0 & 0 & 0 & 0 & 0 & 0 & 0 & 0 & 0 \\
\hline \multicolumn{13}{|c|}{ Lower carbonate sequence: } \\
\hline $65 R-2,11-14$ & Packstone & 0 & 0 & 0 & 0 & 4 & 0.1 & 0 & 4 & 2 & 0 & 0 \\
\hline $65 R-5,73-75$ & Wackestone & 2 & 1 & 0 & 0 & 0 & 0 & 0 & i & 0 & 0 & 10 \\
\hline $65 \mathrm{R}-6,35-37$ & Grainstone & 2 & 0 & 3 & 0 & 0 & 0 & 4 & 15 & 10 & 0 & 0 \\
\hline $65 R-6,41-45$ & Grainstone & 0 & 0 & 2 & 0 & 0.1 & 0 & 0.1 & 13 & 0.1 & 0.1 & 3 \\
\hline $66 \mathrm{R}-1,0-5$ & Grainstone & 0.1 & 0 & 1 & 0 & 0 & 0 & 0 & 0 & 0 & 2 & 0 \\
\hline $66 \mathrm{R}-1,10-15$ & Grainstone & 0.1 & 0 & $i$ & 0 & 0 & 0 & 0 & 20 & 1 & 0 & 0 \\
\hline $67 \mathrm{R}-1,7-11$ & Grainstone & 0.1 & 0 & 0.1 & 0 & 0 & 0 & 0 & 5 & 0 & 0 & 0 \\
\hline $67 \mathrm{R}-1,65-69$ & Grainstone & 0.1 & 0 & 0 & 0 & 0.1 & 0 & 0.1 & 1 & 0.1 & 0 & 0 \\
\hline $68 \mathrm{R}-1,11-16$ & Packstone & 1 & 0 & 1 & 0 & 0 & 0 & 0 & 2 & 2 & 0 & 0 \\
\hline $69 \mathrm{R}-1,20-23$ & Packstone & 0 & 0 & 0 & 0 & 0 & 0 & 0 & 5 & 0 & 0 & 0 \\
\hline $70 \mathrm{R}-1.11-15$ & Wackestone & 0 & 0 & 0 & 0 & 0 & 0 & 0 & 10 & 0 & 0 & 0 \\
\hline $70 \mathrm{R}-1.24-29$ & Packstone & 0.1 & 0.1 & 0.1 & 0.1 & 0 & 0.1 & 0.1 & 0.1 & 0.1 & 0.1 & 0 \\
\hline $71 \mathrm{R}-1,18-22$ & Wackestone & 15 & 0 & 0 & 0 & 0 & 0 & 0 & 2 & 0 & 0 & 0 \\
\hline 71R-1,91-94 & Grainstone & 0.1 & 0 & 0.1 & 0 & 0 & 0 & 0 & 2 & 0 & 0 & 0 \\
\hline $7 \mid \mathrm{R}-1,100-103$ & Grainstone & 0 & 0 & 12 & 0 & 0 & 0 & 0 & 10 & 0 & 0 & 0 \\
\hline $72 R-1,6-10$ & Packstone & 2 & 0 & 4 & 0 & 0 & 0 & 0 & 2 & 0 & 0 & 0 \\
\hline $72 \mathrm{R}-1,18-22$ & Grainstone & 0.1 & 0 & 0 & 0 & 0.1 & 0 & 0 & 0 & 0.1 & 0.1 & 0 \\
\hline $73 \mathrm{R}-1,37-41$ & Packstone & 0 & 0 & 8 & 0 & 0 & 0 & 0 & 10 & 0 & 0 & 0 \\
\hline $73 \mathrm{R}-1,42-45$ & Grainstone & I & 0 & 2 & 0.1 & 2 & 0 & 0 & 1 & 0 & 0 & 0 \\
\hline $74 \mathrm{R}-1,36-42$ & Packstone & 2 & 0 & 2 & 0 & 0 & 0 & 0 & 7 & 0 & 10 & 0 \\
\hline $75 \mathrm{R}-1,0-4$ & Wackestone & 0 & 4 & 0 & 0 & 0 & 0 & 0 & 0 & 0 & 0 & 5 \\
\hline $75 R-1.5-10$ & Grainstone & 3 & 0.1 & 0 & 0 & 0 & 0 & 0 & i & 0 & 0 & 0 \\
\hline $75 \mathrm{R}-1,38-41$ & Packstone & 0.1 & 1 & 1 & 0 & 0 & 0 & 0.1 & 3 & 0 & 0 & 0 \\
\hline $75 \mathrm{R}-1,141-143$ & Wackestone & 2 & 0 & 2 & 0 & 0 & 0 & 0 & 4 & 0 & 0 & 8 \\
\hline $75 R-2,0-4$ & Wackestone & 2 & 0 & 7 & 2 & 0 & 0 & 0 & 7 & 2 & 0 & 0 \\
\hline $76 \mathrm{R}-1.78-83$ & Grainstone & 0.1 & 0 & 1 & 0.1 & 2 & 0.1 & 0 & 2 & 5 & 0 & 0 \\
\hline $76 \mathrm{R}-1,12-14$ & Grainstone & 0.1 & 0 & 1 & 0.1 & 0 & 0 & 0 & 5 & 5 & 0 & 0 \\
\hline $77 R-1,35-38$ & Grainstone & 0 & 0 & 0 & 0 & 0.1 & 0 & 0.1 & 0 & 5 & 0.1 & 0 \\
\hline $77 \mathrm{R}-1,48-52$ & Packstone & 0.1 & 0 & 4 & i & 0 & 0 & 0 & 8 & 0.1 & 0 & 0 \\
\hline $78 \mathrm{R}-1,4-6$ & Grainstone & 0.1 & 0 & 0.1 & 0 & 2 & 0 & 0 & I & 1 & 0 & 0 \\
\hline $78 \mathrm{R}-1,16-20$ & Floatstone & 1 & 0 & 1 & 0 & 15 & 0 & 0 & i & 0.1 & 0 & 0 \\
\hline $78 \mathrm{R}-1,49-52$ & Grainstone & 0 & 0 & 0 & 0 & 0 & 0 & 0 & 3 & 0 & 1 & 0 \\
\hline
\end{tabular}

munity in the high-energy zone. However, in some of the carbonate platforms, rudists dominate both the high-energy and the deeper environment below the wave base, and corals are only rare constituents (Gili, 1993). Rudists formed walls up to several meters in relief (E. Flügel, pers. comm., 1994), as compared with $100-\mathrm{m}$ vertical walls found in modern coral reefs. Thus, coral-rudist buildups had low relief and produced structures morphologically more similar to carbonate banks than to modern coral reefs. The latter situation is applicable on MIT Guyot.

Carbonate sediment composition and the biota constituents indicate that Site 878 is located in the lagoon, near the windward side of the "atoll" (see the discussion below). The presence or absence of deposits interpreted from core studies as deposited in a deeper lagoonal environment was the principal element in recognizing the presence of two depositional systems that participated in the construction of the carbonate buildup at MIT Guyot: (1) a fringing carbonate bank and (2) an atoll-like system. The facies constituents, the sediment composition, and the incorporated biota for these systems are schematically summarized in Figures 7 and 8.

\section{Fringing Carbonate Bank}

In modern Polynesia, the fringing banks comprise (1) an outer coral reef flat and (2) an inner sand flat connected shoreward to (3) the beach, which incorporates sediments derived from the erosion of the volcanic island (Chevalier, 1973; Davies and Montaggioni, 1985). Similar lithologies, with coral debris being only a minor constituent, make up the lower part of the carbonate sequence at Site 878. These lithologies overlie the weathered surface of the volcano; thus, both the lithologic composition of the strata and their depositional setting on the flank of a submerging volcano conform to the fringing carbonate bank depositional system.

These deposits are predominantly skeletal and intraclast grainstones of two slightly different compositions. The dominant type is well-sorted, coarse- to medium-grained grainstone that contains well-rounded skeletal grains (PI. 1, Fig. 1). These skeletal grains are mostly micritized and preserved as micrite envelopes. Mollusk shell fragments, casts of small gastropods, coral debris up to $1 \mathrm{~cm}$ in size (some encrusted by algae), echinoids, sponge debris, crustose coralline algae (Lithoporella), and a few grains of weathered basalt constitute the other constituents.

The second grainstone type is medium-grained, well-sorted, oolitic-oncoidal grainstone and oolitic-skeletal grainstone (Pl. 1, Fig. 2 ). Oncoliths are usually preserved as coatings, whereas the nuclei are already dissolved. The ghost texture of a probable coral fragment could only be seen on a few slides. Ooides are coarse grained, up to $0.7 \mathrm{~mm}$ in diameter, and have multiple radial fibrous coatings. The nucleus is either a micritized bioclast, or the bioclast was leached out and the void infilled by sparry calcite. Ooides constitute only a few percent of the components.

A rhodolith (Sample 144-878A-78R-1, 6-8 cm) is composed of encrusting red algae and is bored, with the boring infilled by ooides and peloids. It represents a shallow-water deposit. The depositional environment could be similar to the modern Muri Lagoon at Raratonga (Scoffin et al., 1985), which is locally floored by rhodolites.

The ooid-skeletal grainstones at Site 878 are frequently cemented by marine, fibrous rim cement. This grainstone facies zone overlies the weathered volcanic substrate at MIT Guyot and extends from 727.5 to 700.5 mbsf (Cores 144-878A-78R through -75R). Even though the sonic and gamma-ray logs are not available for the basal part of the lower carbonate sequence, the neutron porosity, bulk density, and resistivity logs indicate the presence of grainstone beds about 0.5 to $1.5 \mathrm{~m}$ thick, separated by thin, low-porosity, higher density beds (Fig. 9). Stacked foraminiferal-peloid grainstone and skeletal packstone beds are present between 700.5 and 688 mbsf (Cores 144-878A-75R and $-74 \mathrm{R})$. The grainstone zone is interpreted as a carbonate sand shoal zone of a transgressive sequence of a fringing reef/bank stage (Fig. 7A, 9). The carbonate strata above 689.5 mbsf show the presence of lithofacies interpreted as lagoonal deposits. Because of the presence of lagoonal deposits, this part of the carbonate strata is com- 
A
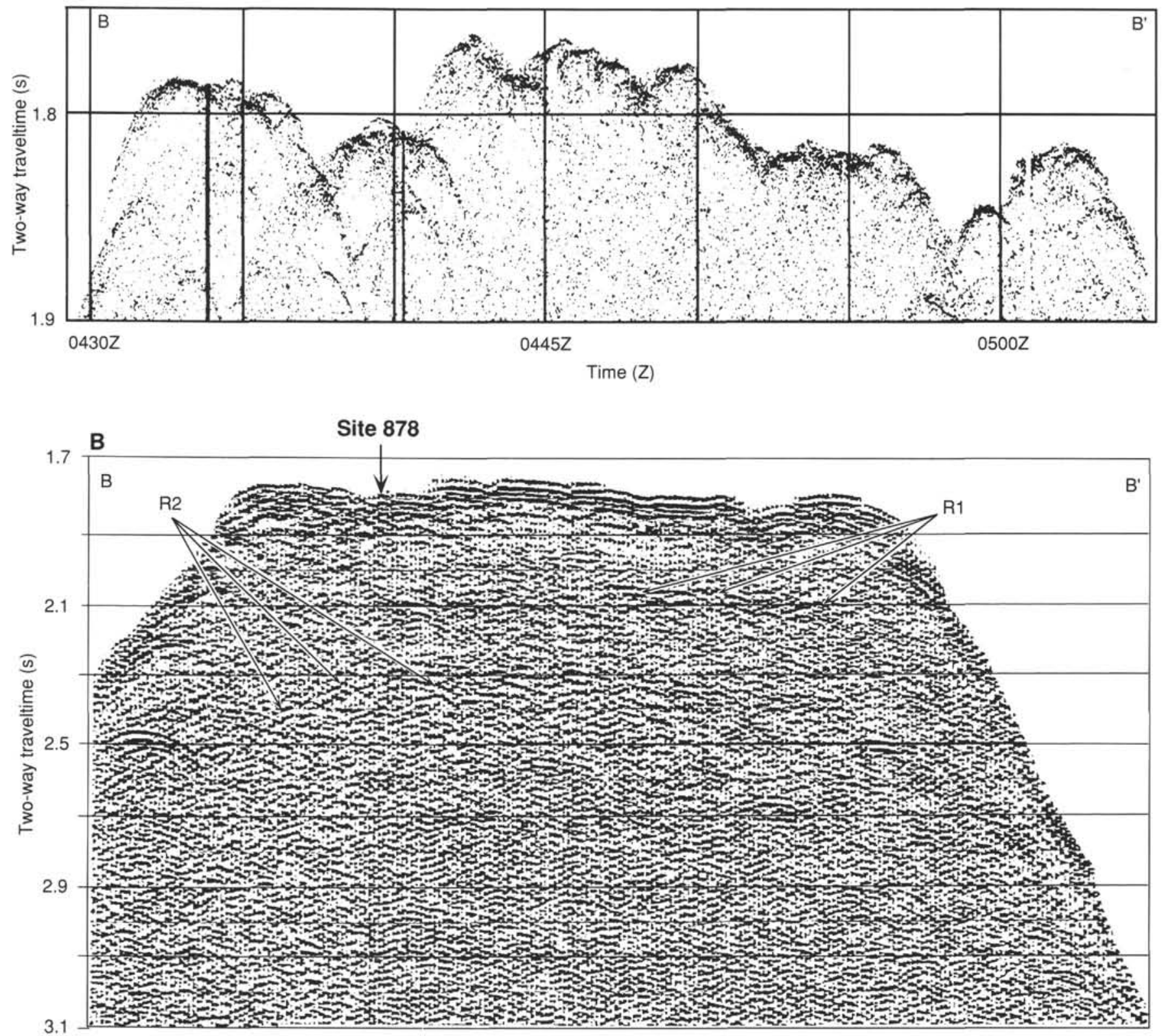

Time (Z)

Figure 2. Profile B-B' collected during Leg 144. A. The $3.5 \mathrm{kHz}$ echo-sounder shows the uneven topography of the MIT Guyot surface with about $30 \mathrm{~m}$ of bumpy relief. B. Reflection R1 of the single-channel seismic profile B-B' corresponds to the top of the volcaniclastic sequence; the R2 reflector is the top of the volcanic basement. The carbonate buildup overlies the R2 reflector. Carbonate deposition was interrupted by a volcanic event marked by reflector R1.

pared with the atoll-like buildup, construction of which has been interrupted by two more periods of fringing carbonate bank development (at 624.5-603.5 and 382-356 mbsf), resulting from igneousrelated processes culminating in a late volcanic eruption event at this guyot.

This second period of fringing carbonate-bank development is represented by stacked grainstone beds deposited near the top of the lower carbonate sequence (624.5-603.5 mbsf, Cores 144-878 A-67R through -65R; Fig. 4). The grainstone forms beds about $0.5 \mathrm{~m}$ thick. Several upward-coarsening beds are indicated by E-logs at the base of this unit. The grainstones are oolitic-skeletal, intraclast-skeletal, skeletal-peloid, and skeletal-oolitic in composition. They are fine- to medium-grained, and moderately to well sorted. The composition and texture are similar to those of the grainstones in the basal part of the lower carbonate sequence, except for the presence of fine- to mediumgrained hard peloids. Ghost skeletal structures preserved in some of the peloids indicate that some, if not most, originated by the micritization of skeletal grains. The other components of the grainstones are rare miliolids and other small benthic foraminifers (Textularidae), fragments of dasycladacean algae, Cayeuxia, fragments of rudist-stromatoporoid bindstone, calcareous sponges encrusted by Lithocodium, molds of small gastropods, and thick-wall mollusk shell fragments. The grainstone is mostly poorly cemented with $25 \%-30 \%$ interparticle porosity. The upward-coarsening grain size in some of the beds in the lower part of the stacked grainstone zone, the increasing occurrence of ooids, and the faunal assemblage indicates deposition in an increasingly shallow and higher energy fringing bank environment (Fig. 7B). The shallowing is interpreted to reflect a rise in the guyot surface that occurred 

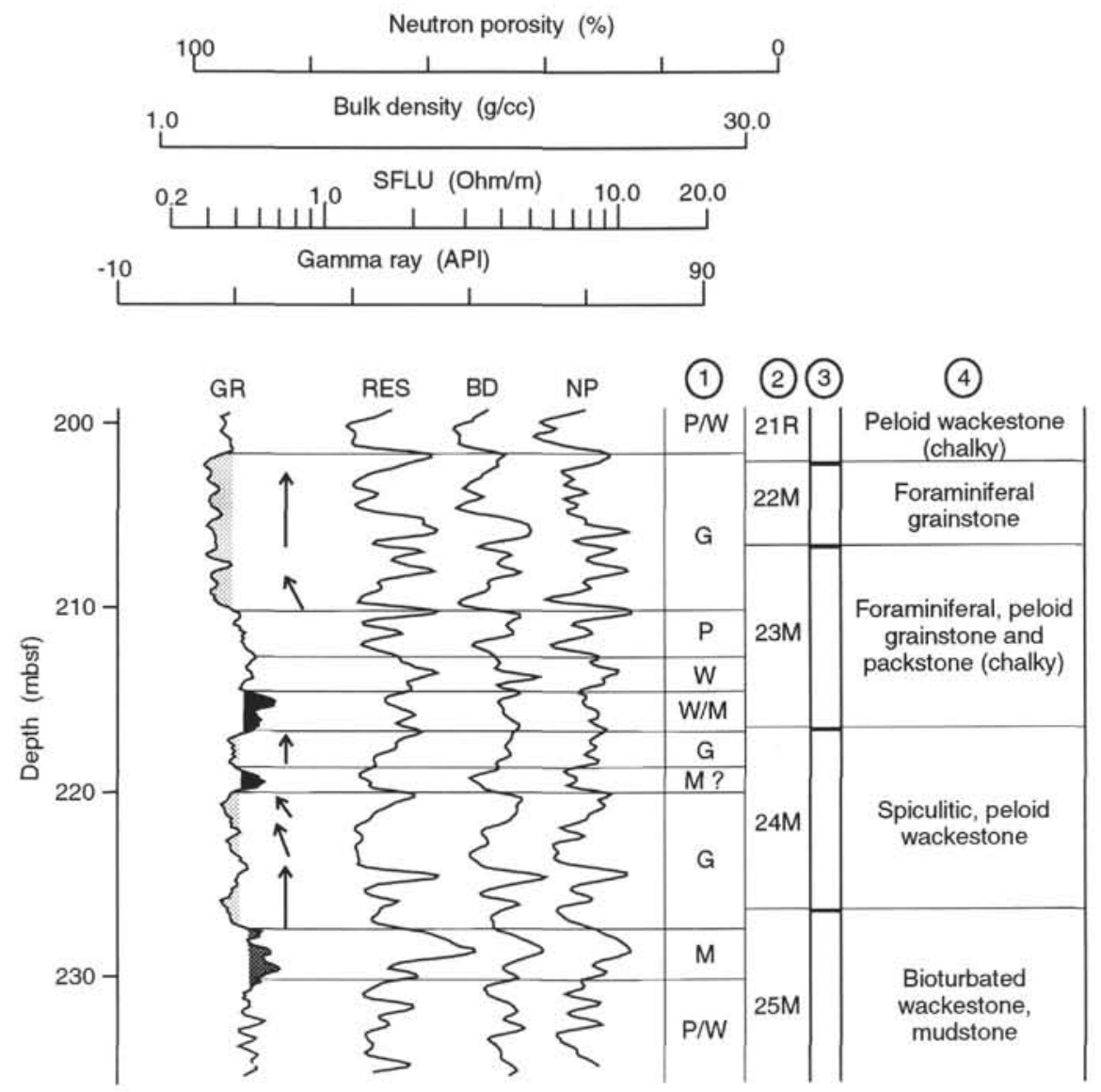

Figure 3. An example of facies interpretation from the wireline logs. $\mathrm{GR}=$ gamma ray, $\mathrm{RES}=$ shallow-focused resistivity, $\mathrm{BD}=$ bulk density, $\mathrm{NP}=$ neutron porosity. Encircled numbers as follows: $1=$ interpreted facies $(\mathrm{G}=$ grainstone, $\mathrm{P}=$ packstone, $\mathrm{W}=$ wackestone, and $\mathrm{M}=$ mudstone $) ; 2=$ corresponding cores; $3=$ core recovery within the cored interval is shown by the thickness of the black line; and $4=$ lithofacies recovered by cores. The vertical arrows indicate the buildup of sand beds of similar grain size; arrows inclined to the left indicate upward coarsening within the unit (based on wireline log interpretation).

before the volcanic eruption. The presence of meniscus cement near the top of the sequence (Sample 144-878A-65R-6, 41-45 cm) provides additional support for this interpretation.

A 205-m-thick, volcanic-limestone debris unit resulting from the volcanic explosion in MIT Guyot separates the lower and upper carbonate sequences (Fig. 4). The third period of stacked grainstone beds deposition, interpreted from E-logs as related to the fringing carbonate bank development, is located at 382-356 mbsf (Cores 144-878A$42 \mathrm{M}$ through $-38 \mathrm{M}$ ), near the base of the upper carbonate sequence. The stacked grainstone unit overlies the basal open lagoon, or openshelf marine deposits, as indicated by the presence of pelagic microfauna (Premoli Silva, Haggerty, Rack, et al., 1993) deposited before the fringing carbonate bank was constructed. This grainstone unit is similar in composition and texture to the upper grainstones of the lower carbonate sequence, including the occurrence of ooids and oncoliths, which indicate deposition in a similar environment.

Interpretation of the logs suggests intercalation of packstone and wackestone lithofacies within the upper one-third of the stacked grainstone unit (Fig. 10). The lack of any volcanic grains in these grainstones indicate that the volcanic cone was already submerged during carbonate sand deposition, or had a very low relief. However, considering that the site is located at the windward edge of the guyot, suggested by interpretations of the dipmeter data and wind circulation modeling for the mid-Cretaceous Pacific Ocean (Barron and Peterson, 1990), the lack of volcanic material in the sediments is not unexpected. The presence of the stacked grainstone beds near the base of the upper carbonate sequence indicates a brief period of continued fringing bank facies development, which develops upward into an atoll-like carbonate system.

\section{Atoll-like Facies Assemblage}

The term atoll-like is used here, for the lack of a more suitable description, to describe the overall mid-Cretaceous facies. The lithofacies comprising this assemblage document the presence of a lowenergy, deeper, restricted, lagoonal depositional environment in the center of the "atoll," which was rimmed by a belt of higher energy, shallow-water facies with bioconstructions. Even though this midCretaceous atoll-like feature lacked modern coral reefs at its periphery, the outer rim had to have some bioconstructions either in a form of bioherms or algal encrustations to be capable of withstanding the pounding of waves and protecting the environment located behind it. This, together with the presence of enclosed central lagoon, is morphologically closer to an atoll than to a bank.

The sediment composition, texture, and biota enclosed by individual facies are schematically summarized on Figure 8. Only a portion of the environmental system interpreted here as encompassing lagoon to beach facies was drilled at Site 878. The presence of "reef" flat and biostromal front is hypothetical. Drilling results at Wodejebato Guyot (Sites 874 through 877 ) and Seiko Guyot (Site 879) document the presence of scattered bioconstructed mounds near the edges of guyots.

Studies of the sediment composition in cores (Premoli Silva, Haggerty, Rack, et al., 1993), thin sections, and grain-size variation within beds interpreted from wireline logs indicate that the atoll-like facies dominated deposition of the middle part of the lower carbonate sequence (689.5-624.5 mbsf) and most of the upper carbonate sequence (356-0 mbsf). The proportion of major facies in both carbonate sequences as derived from log interpretation is diagrammatically shown in Figure 6. It indicates that the depositional environment has 


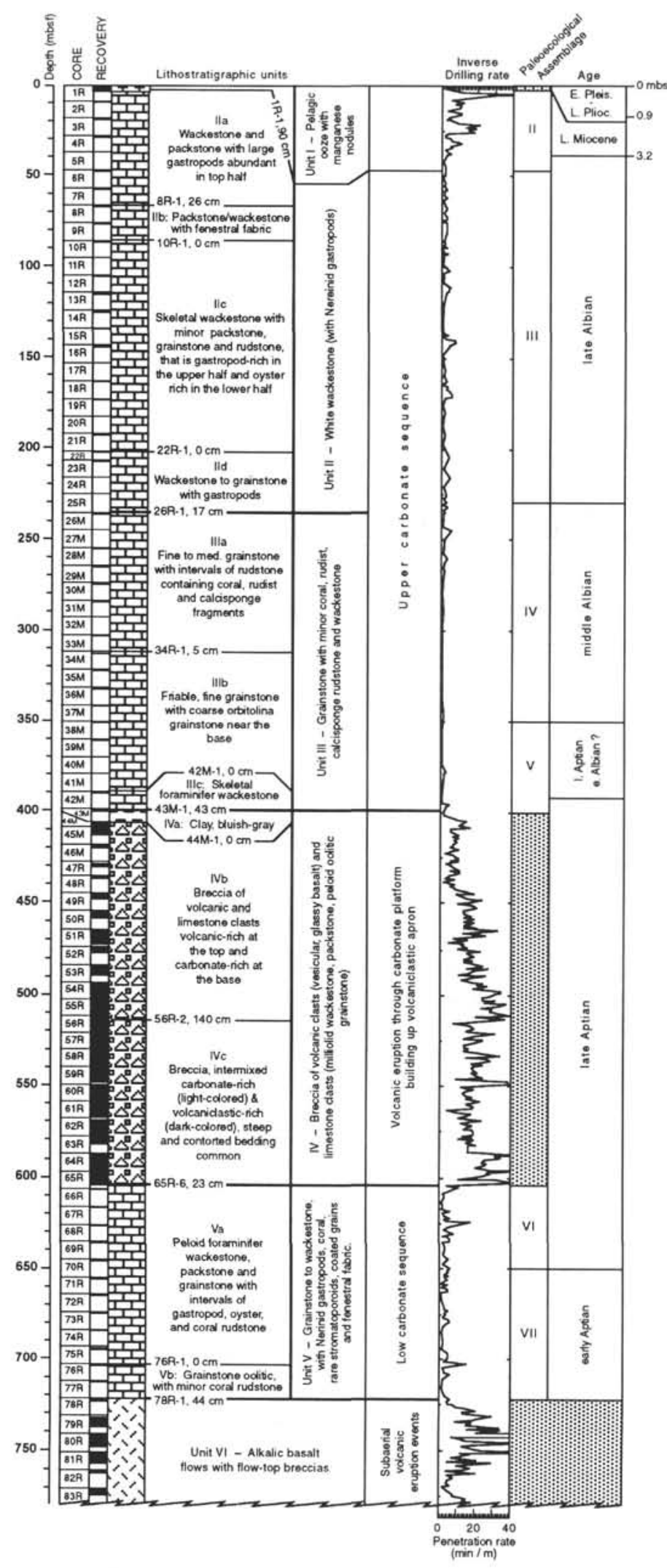

Figure 4. Stratigraphic chart for Hole 878A revised after Premoli Silva, Haggerty, Rack, et al. (1993). As discussed in the text, the composition and boundaries of the subunits do not fully correlate with the interpretation of the wireline logs (see Figs. 9, 10). not changed substantially throughout development of the buildup. An increase in the mudstone and wackestone facies in the upper part of the upper carbonate sequence demonstrates more frequent development of deeper lagoonal conditions.

As interpreted from a combination of wireline log interpretations, core descriptions, and thin-section descriptions, the facies that comprise the atoll-like assemblage at Hole 878A are as follows: lagoon, carbonate sand shoal, bioconstruction and its debris, tidal zone, and exposure surface. The individual facies are described in more detail below.

\section{Lagoonal Facies}

Three subfacies can be recognized on the basis of differences in sediment composition: deeper lagoon, shallow lagoon, and lagoon margin. Wireline log interpretation suggests that the thickness of fine-grained carbonate deposits varies from 0.5 to $3 \mathrm{~m}$, with most of the deposits less than $1 \mathrm{~m}$ thick. Core analyses of these deposits show that they are bioturbated biomicrite and fine-grained skeletal wackestone. The biomicrites have a distinctive composition, with few ostracod shells, miliolids, rare Cuneolina, and sponge spicules (Pl. 1, Fig. 3). Large foraminifers and fine-grained mollusk debris occur in trace amounts. The wackestone is fine-grained, skeletal, or peloid-skeletal in composition, and has mollusk shells, echinoid debris, rare oncoliths, and molds of small gastropods. Trace amounts of molds of coral, rudist, and codiaceae algae debris also occur. Skeletal grains are unsorted, angular to subangular in shape, and deposited within a micritic matrix. Both the wackestone and biomicrite facies are bioturbated. The deeper lagoon interpretation is supported by a scarce faunal assemblage low in diversity.

The shallow lagoon subfacies comprises peloid-skeletal packstone and less wackestone. Peloid packstones have merged peloid texture, with well-sorted peloids, some with bimodal distributions. The coarser fraction is composed of hard peloids originating from the micritization of skeletal grains; the finer peloids, with fuzzy boundaries, are probably fecal pellets. The biota in this subfacies are small benthic foraminifers (Textularidae), miliolids, ostracodes, mollusk debris (some thick-walled shells), echinoids, rudists, coral debris, small gastropod molds, nerineid gastropods, red algae, Cayeuxia, and dasycladacean algae debris. Stromatolites, oncoliths, and orbitolinids are very rare. Better sorting of sedimentary particles and the higher variability of the biota in this subfacies indicate deposition in a shallow lagoon, the bottom of which was occasionally reworked during storms or by intensified currents.

\section{Carbonate Sand Shoal Facies}

Carbonate sand is one of the most distinct facies of modern atolls and carbonate banks. It occurs as an easily recognizable sand belt leeward of the reef platform, extending into the lagoon and forming beaches, sand spits, and cays on the protected side of the lagoon.

Interpretation of wireline logs on the basis of the characteristics displayed in Figure 3 indicates that grainstone/packstone facies occur most commonly in beds $2-5 \mathrm{~m}$ thick, with some up to $10 \mathrm{~m}$ thick. The latter beds are composite, with a blocky log pattern similar to the signature of sand barriers. In the thinner beds, a coarsening-upward trend and/or a consistent grain size throughout the bed are the most common gamma-ray log signatures of this facies. Upward-fining beds are less common.

Core and thin-section analyses show the grainstone as mostly medium grained. Sorting ranges from excellent to poor, but the wellsorted grainstones seem to dominate. Grains are rounded and reworked. The grainstone is peloid-skeletal, skeletal-peloid (PI. 1, Fig. 4 ), and intraclast-skeletal in composition. Few oolitic-skeletal grainstone beds occur within the atoll-like facies assemblage in the lower carbonate sequence. The dominant constituents of the grainstones are mollusk shell fragments (commonly micritized) and subordinate amounts of echinoid debris and small benthic foraminifers. Less common are molds of gastropod shell fragments, pelecypods, corals, 


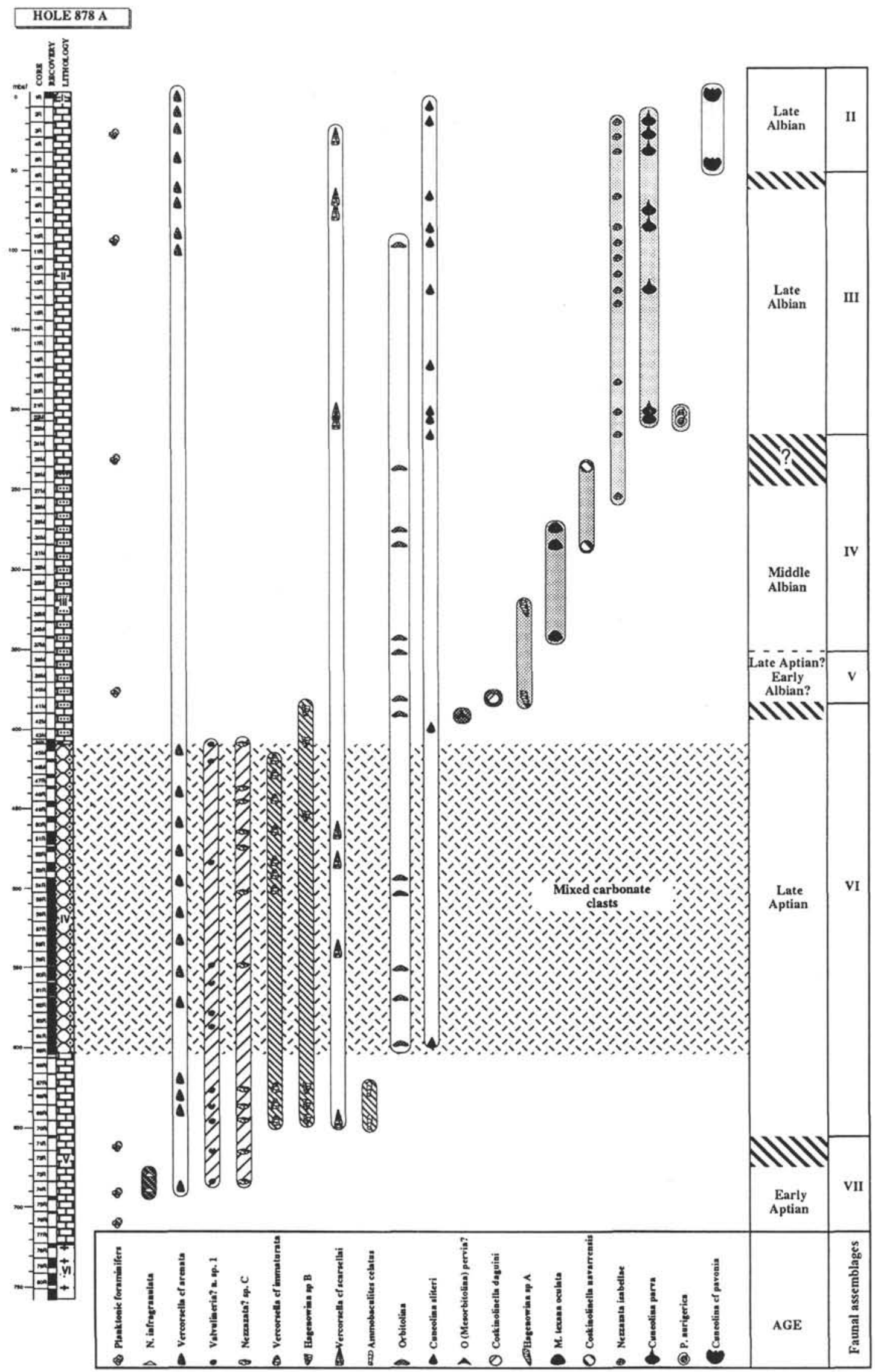

Figure 5. Biostratigraphic chart for Hole 878A. 


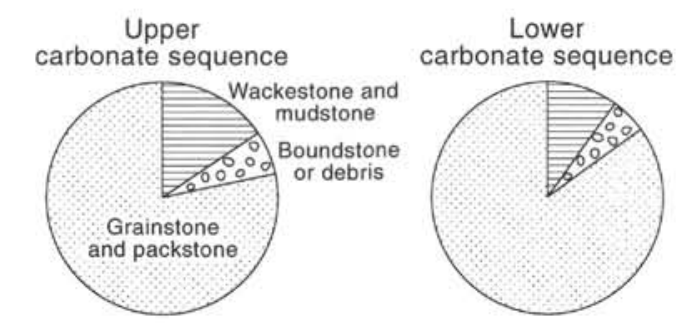

Figure 6. Proportion of major facies constructing the lower and upper carbonate sequence in Hole $878 \mathrm{~A}$, as derived from wireline log analyses.

rudists, large foraminifers (orbitolinids) (Pl. 1, Fig. 5), tubiphytes, red algae, codiaceae algae (Cayeuxia; Pl. 1, Fig. 6), stromatoporoids, and ostracodes. Sporadic oncoliths, micrite intraclasts, and oolites occur. Grainstones are poorly cemented, with an interparticle porosity ranging from $15 \%$ to $40 \%$ (Pl. 4, Figs. 1, 3).

\section{Bioconstruction and Related Rubble Facies}

The presence of coarse debris of rudists, coral-stromatoporoid bindstone, and floatstone in cores with concurrent low-porosity, highdensity, high-resistivity signatures on wireline logs suggests the presence of several levels of bioconstruction either of biohermal or biostromal origin and/or their debris. No data is available on the lateral extent of potential bioconstructions; however, the reflection seismic profile shows that they occur within the inner guyot perimeter ridge at Wodejebato Guyot, with the ridge less than $0.5 \mathrm{~km}$ wide (Premoli Silva, Haggerty, Rack, et al., 1993). The core data allow us to establish whether the bioconstructed body represents mechanical accumulation of skeletal remains (biostrom) or whether binding was an instrumental part of the accumulation process (bioherm). Because the vertical dimensions of bioconstructed bodies, as interpreted from wireline logs, were less than a few meters thick, the bioherm terminology could be an appropriate description. In the lower carbonate sequence, bioconstructed carbonates (or rubble) form thin beds at 724.5-725.5, $720.5-721.5,707-709$ (rubble with corals), 683-684, 676-677, 650 651 , and 614.5-615.5 mbsf (thin coral-stromatoporoid boundstone and nerineid gastropod rudstone beds; Pl. 2, Fig. 1). Rubble with coral occurs at 603-607 mbsf. In the upper carbonate sequence, similar bioconstructions are present at 284-286 mbsf (where blue coral was found; PI. 2, Fig. 2), 244-252 mbsf (rubble bed with rudists), 201 mbsf (oyster shell accumulation; Pl. 2, Fig. 3), 178-180 mbsf, 167174 mbsf (rudist-stromatoporoid boundstone), 139-144 mbsf, and 135-137 mbsf (rubble beds).

Core and thin-section analyses indicate that the coral-stromatoporoid rudstone and floatstone subfacies contain molds of corals up to $2 \mathrm{~cm}$ in diameter set in a matrix of coarse grainstone, which consists of bivalves, gastropods, miliolids, intraclasts, and coated grains. A coralstromatoporoid bindstone subfacies is made up of corals, stromatoporoids, and calcisponges encrusted by encrusting foraminifers (PI. 3, Fig. 1); worm tubes with a concentric shell structure; and bacterialthrombolitic peloid packstone growth forms (Jansa et al., 1989; Pl. 3, Fig. 2). The latter have tops encrusted by Bacinella algae (PI. 3, Fig. 3 ). The occurrence of bindstone facies may be interpreted as an indication of the presence of small bioherms constructed either at the outer rim of the atoll or in the shallow lagoon ("patch reef"-like growth forms). The more common occurrence of corals in bioconstructed carbonates of the lower carbonate sequence suggests the presence of coral "bioherms" at the front of the fringing bank system.

In the upper carbonate sequence, the floatstone and rudstone subfacies become dominated by nerineid gastropod and rudist shell fragments surrounded by a pelecypod grainstone matrix (Pl. 3, Fig. 4). Minor amounts of orbitolinids and small benthic foraminifers (Textularidae) are present; stromatoporoids are rare. Algae, represented by red algae (Lithoporella), green algae (Cayeuxia), and coralline algae, are relatively common, although they do not represent more than a few percent of the total grain composition. The bioconstruction subfacies with corals, as found in the lower carbonate sequence, is less common in the upper sequence.

\section{Spiculitic Biomicrite Facies}

This facies is rare and was observed only at the base of the upper carbonate sequence (Core 144-878A-43M, 399.3-406.0 mbsf). The characteristic feature is the presence of sponge spicules, which are replaced by calcite or occur as molds (Pl. 3, Fig. 5). The other components are planktonic foraminifers (globigerinids), echinoids, thin-shelled mollusk debris, and small benthic foraminifers. Cuneolina and Cayeuxia are rare. The matrix is micrite with soft, finegrained peloids. The sediment composition indicates a low-energy, open lagoon connected to an open ocean. The lack of bryozoans and large foraminifers indicates that this facies was not deposited in an open neritic environment.

\section{Orbitolinid Grainstone Facies}

This facies occurs in Section 144-878A-37M-1 (341.6-351.2 mbsf). It is an intraclast-orbitolinid floatstone, dominated by orbitolinids (30\%), with subordinate mollusk shell and echinoderm fragments, peloids, and rare oncoliths. Intraclasts, up to $7 \mathrm{~mm}$ in size, are composed of algal crusts, skeletal wackestone with coarse mollusk shell debris, and calcareous sponge fragments. Although large foraminifers are a common constituent of deep reef-front facies, the lack of bryozoa suggests that this sediment was deposited on the leeward side of a "reef-flat" sand shoal.

\section{Fenestral Fabric and "Exposure Surfaces"}

The presence of intervals with fenestral fabric (Fig. 10) is of great importance, because it is one of a few criteria indicating that the surface of the sediment was built into the tidal zone. Fenestral fabric has been observed in cores in the lower carbonate sequence at 714 and $663 \mathrm{mbsf}$ (associated with oolites) and in the upper sequence at 111, 77 (Pl. 2, Fig. 3; Pl. 3, Fig. 6), 86.96, 71.5, and 67 mbsf. Thin-section analyses show that the limestone is a skeletal-peloidal packstone permeated by bacterial peloids and blue-green algal clots and fragments. Occasionally, the fenestra are partially filled by fibrous, microstalactitic cement ( $86.96 \mathrm{mbsf}$ ). If iron-oxide staining is considered an indicator of possible exposure, then such intervals occur at 721 and $651 \mathrm{mbsf}$ (associated with occurrence of ooides), and in the upper limestone sequence at $71.5 \mathrm{mbsf}$ in a bed with fenestral fabric. No other evidence of exposure was recovered in the cores. The wireline logs show the presence of several thin, very dense beds, which could be interpreted as hardgrounds or exposure surfaces; however, because the core control necessary to establish their composition is lacking, this interpretation remains hypothetical.

\section{LIMESTONE DIAGENESIS}

When a portion of the carbonate reef/atoll complex is subaerially exposed, a meteoritic groundwater lens occupies the upper part of the section. Meteoric diagenesis alters the petrographic and isotopic character of deposited sediments, most notably at the water table and at the air/sediment interface (Moore, 1989). Thus, a detailed study of carbonate diagenesis may provide information about mid-Cretaceous sealevel fluctuations. The normal sequence for diagenesis of a marine sediment, during relative lowering of sea level, would be to move from the marine phreatic zone, through the mixing zone, into the meteoric phreatic zone, and finally into the vadose zone environment. It would be rare for a sediment to move directly from the marine phreatic into the meteoric vadose environment, except in areas of very rapid relative uplift. This sequence would be reversed during transgression. In periods with a prolonged stable sea level, carbonate sediments accumulate up to, but not much above, the high-tide level. Under such conditions, 

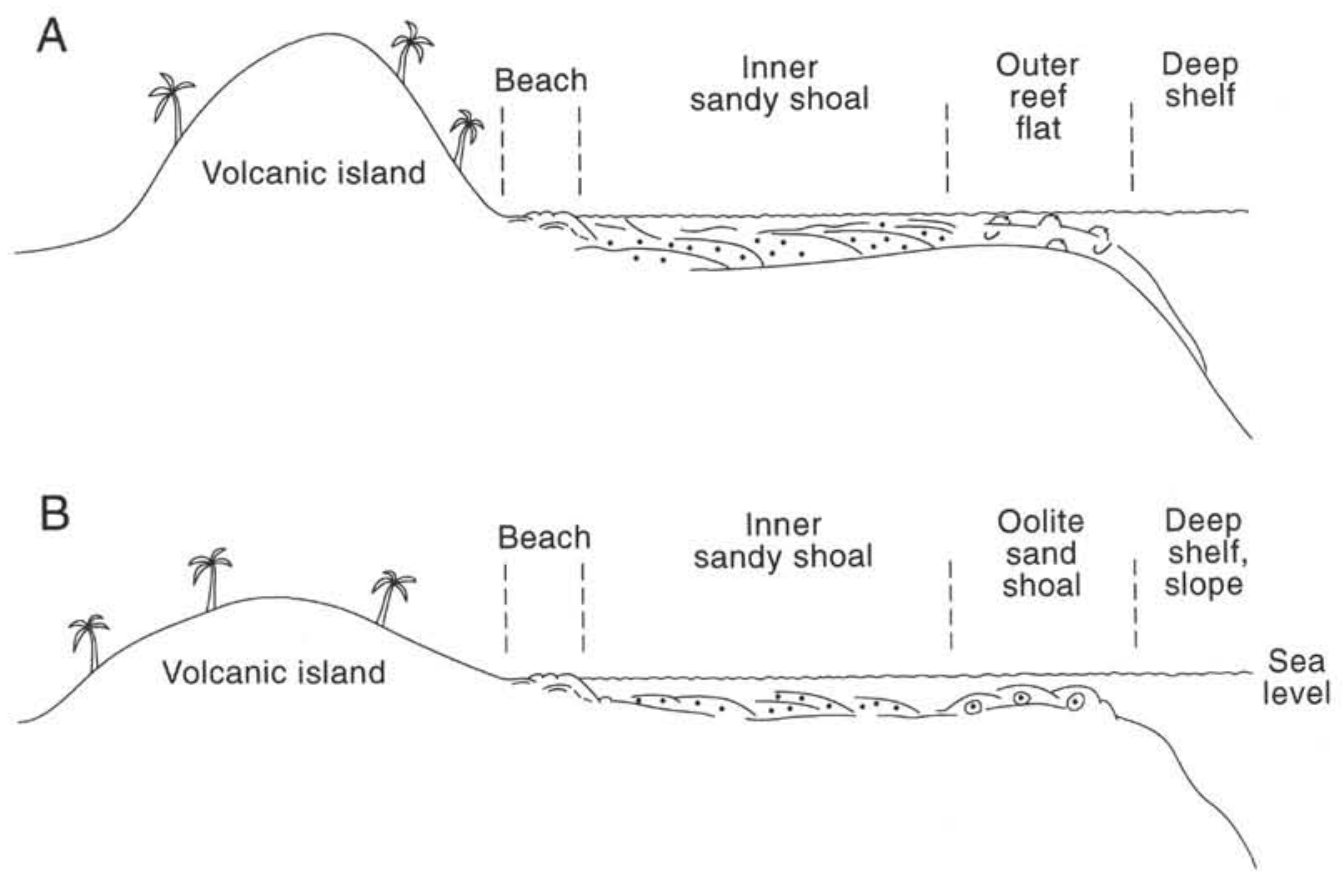

Figure 7. Idealized depositional facies (A) across fringing reef and (B) across fringing carbonate bank.

the vadose zone may be almost nonexistent. Only during periods of significant fluctuation of sea level may extensive vadose diagenesis occur (Moore, 1989). "May occur" should be stressed because of the strong dependency of vadose and phreatic zone development on the climate. In areas or periods of low rainfall, the diagenetic changes are slow or almost nonexistent, owing to the lack of a freshwater phreatic zone (Longman, 1980). In contrast, during high rainfall, the processes are rapid and the Ghyben-Herzberg freshwater lens under oceanic islands is thicker (Wheeler and Aharon, 1991).

Other factors influencing carbonate diagenesis are topography and the distribution of porosity and permeability in sediments, which influence the geometry of the freshwater phreatic zone. It is our experience that the preservation of cement stratigraphy of the vadose zone during fluctuations of sea level is rare because it is destroyed during the following stage of freshwater phreatic diagenesis. Significant meteoric diagenetic overprint resulting from floating meteoric lens, based on present knowledge of the Pleistocene, is only established during sealevel standstill (Moore, 1989). It is reasonable to expect freshwater diagenesis to be more extensive during the volcanic-island, fringingcarbonate-bank/reef development stage than during the atoll stage, owing to higher island relief and related thicker freshwater lens than that at atolls. At atolls, the freshwater lens could be only a few meters thick and, in low rainfall areas, even periodically missing (Wheeler and Aharon, 1991). Extensive literature exists on carbonate diagenesis and cementation. Summaries published by Bathurst (1971), Longman (1980), James and Choquette (1983, 1984), Schroeder and Purser (1986), Moore (1989), Budd and Land (1990), Tucker and Wright (1990), Quinn (1991), and Friedman et al. (1992) provide detailed descriptions of various carbonate diagenetic environments that were applied to the study of carbonate diagenesis at Hole 878A.

A study of thin sections (Table 1) and cores from Site 878 showed a complete lack of plant and volcanic detritus within the carbonate strata of the atoll-like facies assemblage. The lack of these constituents is an indication that, at the time of the atoll-like construction stage, MIT Guyot was a low-relief feature, probably nonvegetated, having an "atoll" surface near the ocean surface, as is true for some of the modern atolls (e.g., Fabre and Huon atolls in New Caledonia; Chevalier, 1973). In such a morphologic setting, only a major eustatic sea-level drop could leave a visible diagenetic imprint.
One of the diagenetic characteristics of the limestones at MIT Guyot, with the exception of the basal $30 \mathrm{~m}$ of the carbonate strata, is that they are poorly cemented (see Pls. 1, 3, 4). Dissolution and replacement of unstable grains of aragonite and high $\mathrm{Mg}$-calcite by calcite is pervasive. No aragonite or high $\mathrm{Mg}$-calcite was identified during the EDS and electron microprobe study (Table 1) of the limestones. Grain dissolution, limestone chalkification (discussed in more detail later), and poor cementation all result in observed high inter- and intraparticle porosity. The neutron porosity log indicates that limestone porosity fluctuates between $20 \%$ and $40 \%$, which is corroborated by thin-section analyses. An idealized diagenetic stratigraphic sequence derived from a study of thin sections at Site 878 is as follows:

1. Micrite and silt-sized peloidal precipitation; formation of micrite envelopes (marine, marine[?] phreatic diagenetic zone) (Pl. 4, Fig. 1).

2. Fibrous rim cement precipitation, botryoidal crust, and nodes (marine zone); some of the crystals of the fibrous rim have planar faces, which may indicate original, high $\mathrm{Mg}$-calcite composition of some of the cements (Pl. 3, Fig. 4).

3. Microstalactitic cement precipitation (marine and also vadose zone) (Pl. 4, Fig. 2; Aissaoui and Purser, 1983).

4. Palisade rim cement (phreatic zone) (Pl. 4, Fig. 3).

5. Aragonite and high $\mathrm{Mg}$-calcite dissolution (freshwater phreatic and/or vadose zone).

6. Syntaxial overgrowth on echinoderms (active zone in freshwater phreatic zone) (Pl. 4, Fig. 4); also occurs in near-surface marine or mixing zone environments (Tucker and Wright, 1990).

7. Short-bladed or small equant microspar $(2-30 \mu \mathrm{m})$ scattered on grain surfaces with patchy distribution (in thin section, patches with some cement occur next to patches lacking any cement) (vadose zone). The heterogeneous distribution of patchy cement indicates inhomogeneous distribution of fresh groundwater in the original sediment; a phreatic origin for this sparry calcite type could be argued, but the patchy cement distribution is strong and of vadose origin (Goter and Friedman, 1988).

8. Short-bladed and/or equant microspar rims with some of the rhombohedra "floating" in solution voids, molds, and vugs (freshwater phreatic, active saturated zone, or marine phreatic zone) (PI. 4, Fig. 5). 


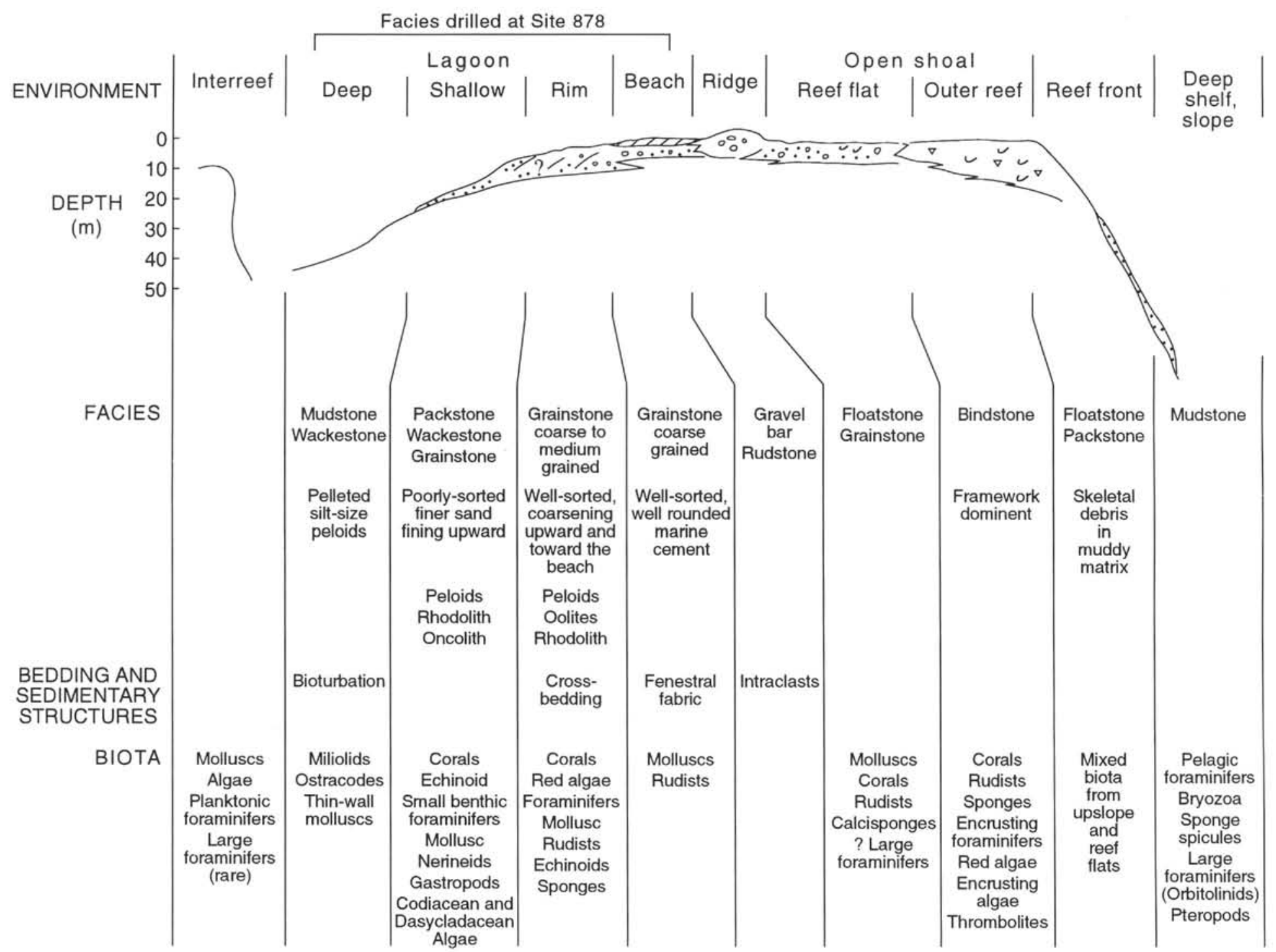

Figure 8. Idealized cross section of the windward portion of a mid-Cretaceous facies across the guyot in the western Pacific. The drawing shows depositional environments and the corresponding composition of deposited sediments and biota present. Note that only a portion of the lagoon facies was sampled at Site 878. The guyot profile is a hypothetical reconstruction that combines drilling results from other guyots drilled during Leg 144 with modern atoll studies. The corresponding facies, sedimentary textures, and biota shown are based on the results of core and thin-section studies from Site 878 . 


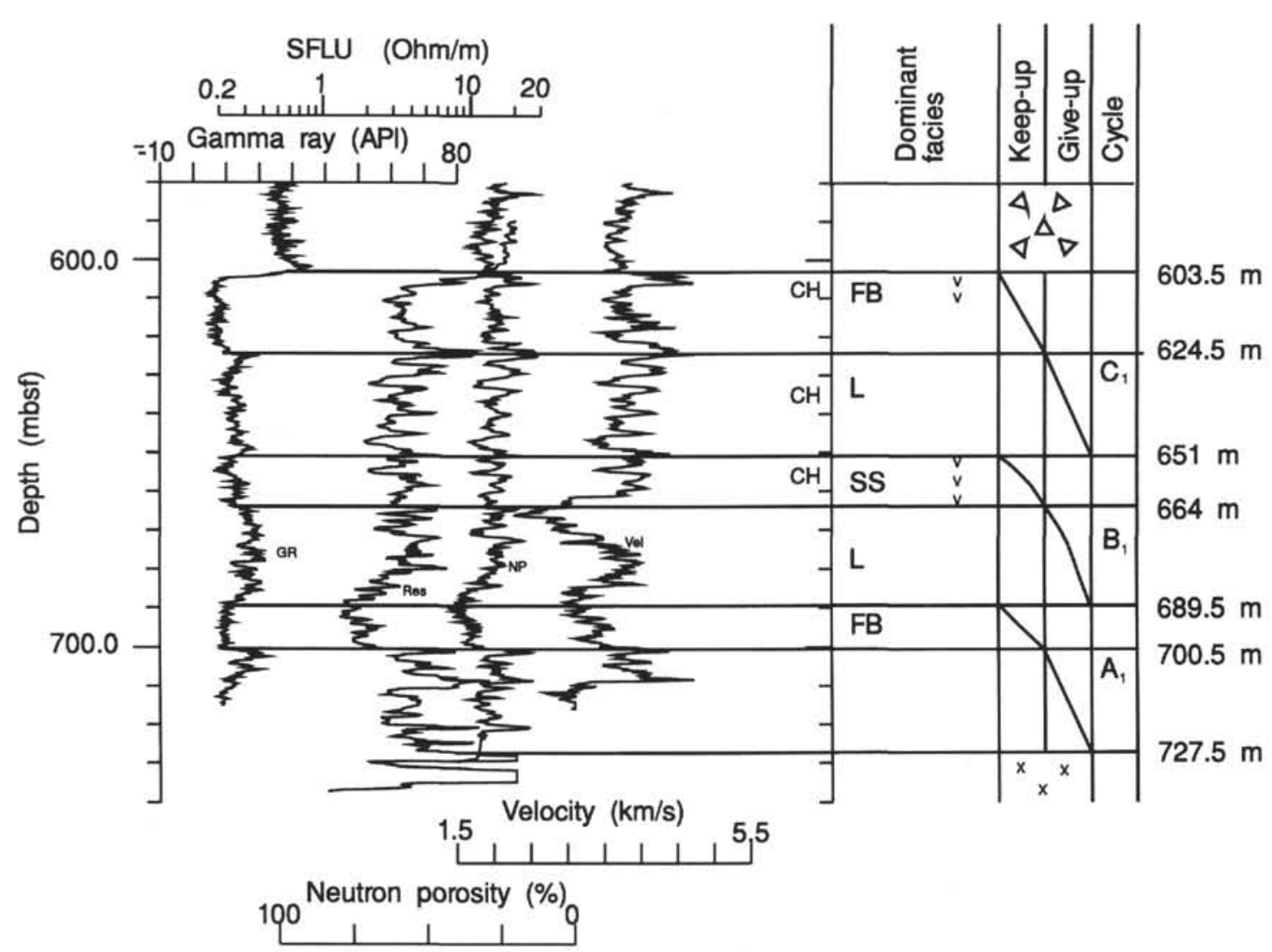

Figure 9. Schematic cyclicity in the catch-up/keep-up (build-up) and give-up (flooding, deepening) facies in the lower carbonate sequence at Hole 878 A $(604.3-722.5 \mathrm{mbsf}) . \mathrm{GR}=$ gamma-ray, $\mathrm{RES}=$ focused resistivity, $\mathrm{NP}=$ neutron porosity, $\mathrm{VEL}=$ sonic velocity, $\mathrm{F}=$ flooding, $\mathrm{L}=$ lagoon, $\mathrm{SS}=$ carbonate sand shoal, $\mathrm{FB}=$ fringing bank, $\mathrm{OL}=$ open lagoon, $\mathrm{s}=$ solution, $\mathrm{f}=$ fenestral fabric, $\mathrm{v}=$ vadose diagenesis, and $\mathrm{CH}=$ chalky limestone.

9. Rare, large poikilotopic sparry calcite crystals indicate either rapid growth in a freshwater phreatic zone as observed at Tarawa Atoll by Marshall and Jacobson (1985), or precipitation in a deepmarine environment close to the calcite lysocline (Moore, 1989).

10. Dolomite rhombs (PI. 4, Fig. 6; late diagenesis).

None of the limestone samples studied from MIT Guyot showed a complete, idealized cement stratigraphy cycle. Furthermore, in some of the thin sections, the cement stratigraphy at one place on the thin section differs from the stratigraphy only a few millimeters away in the same thin section (Pl. 4, Fig. 5). The observed inhomogeneity in the cementation supports the influence of meteoric diagenesis on the carbonate strata of MIT Guyot.

Selected representative samples were analyzed for iron, magnesium, and strontium to corroborate the origin of the carbonate cements. Results of chemical analyses of calcite cements are summarized in Table 2, where they are compared with similar analyses of cements from Anewetak Atoll by Saller and Moore (1991). In contrast to stable isotope analyses, calcite cements analyzed for iron, strontium, and magnesium concentrations could include cements that are volumetrically quite minor, such as the patchy, uneven, or irregularly distributed equant rim cements. They can also include single crystals, $5-20 \mu \mathrm{m}$ in size, that cannot be analyzed for their isotopic composition, but are important components of carbonate diagenesis. Crystals identified as dolomites from petrographic analyses were also analyzed.

Analyses of the calcite cements from the MIT Guyot show that all of the cements are low Mg-calcite with relatively constant 1-1.4 $\mathrm{mol} \% \mathrm{MgCO}_{3}$ concentration. No iron was detected by microprobe analyses; all cements are non-ferroan. Short equant rim cements and columnar spar replacing the originally fibrous marine aragonite ce- ment generally have the highest magnesium content, but the small difference is not statistically meaningful.

Strontium shows a large variation in some individual cement crystals. The highest strontium concentration is found in short equant rims and columnar sparry calcite crystals replacing the fibrous rim cement, which is rich in inclusions, and in extension of these crystals into voids (clear crystal). The lowest strontium is in chalkified (recrystallized) micrite and in peloids that infill burrows in the chalkified micrite. Similar concentrations of strontium were found in sparry calcite mono-crystal overgrowth rims on echinoids. In comparison to Anewetak Atoll calcite cements, Site 878 cements have a slightly higher overall concentration of magnesium, but lower variability in magnesium content among individual cement types. In summary, the strontium content of cements at MIT Guyot is quite variable between individual cement types and has a similar range of concentrations to the cements at the Anewetak Atoll. In both locations, the highest strontium concentration is found in the short equant sparry calcite rim cements. Meteoric diagenesis may decrease the strontium content of marine carbonate sediments from $3000-6000$ to $100-500 \mathrm{ppm}$ (Moore, 1989). The strontium content of $<380 \mathrm{ppm}$ in cements from MIT Guyot interpreted from cement stratigraphy as precipitated in meteoric diagenetic environment, does not contradict such an interpretation. The low magnesium $\left(<1.4 \mathrm{~mol} \% \mathrm{MgCO}_{3}\right)$ and strontium $\left(<380 \mathrm{ppm} \mathrm{Sr}^{2+}\right)$ concentrations in cements of the MIT Guyot are supporting evidence for precipitation and diagenetic alteration in meteoric waters if the conclusions of James and Choquette (1984), Moore (1989), and Saller and Moore (1991) about the usefulness in distinguishing calcite cements precipitated in freshwater from those precipitated in a mixture of fresh and marine water are valid.

Dolomite rhombs, $180 \mu \mathrm{m}$ in diameter, found floating in the micrite matrix near the base of the lower carbonate sequence have a consistent 


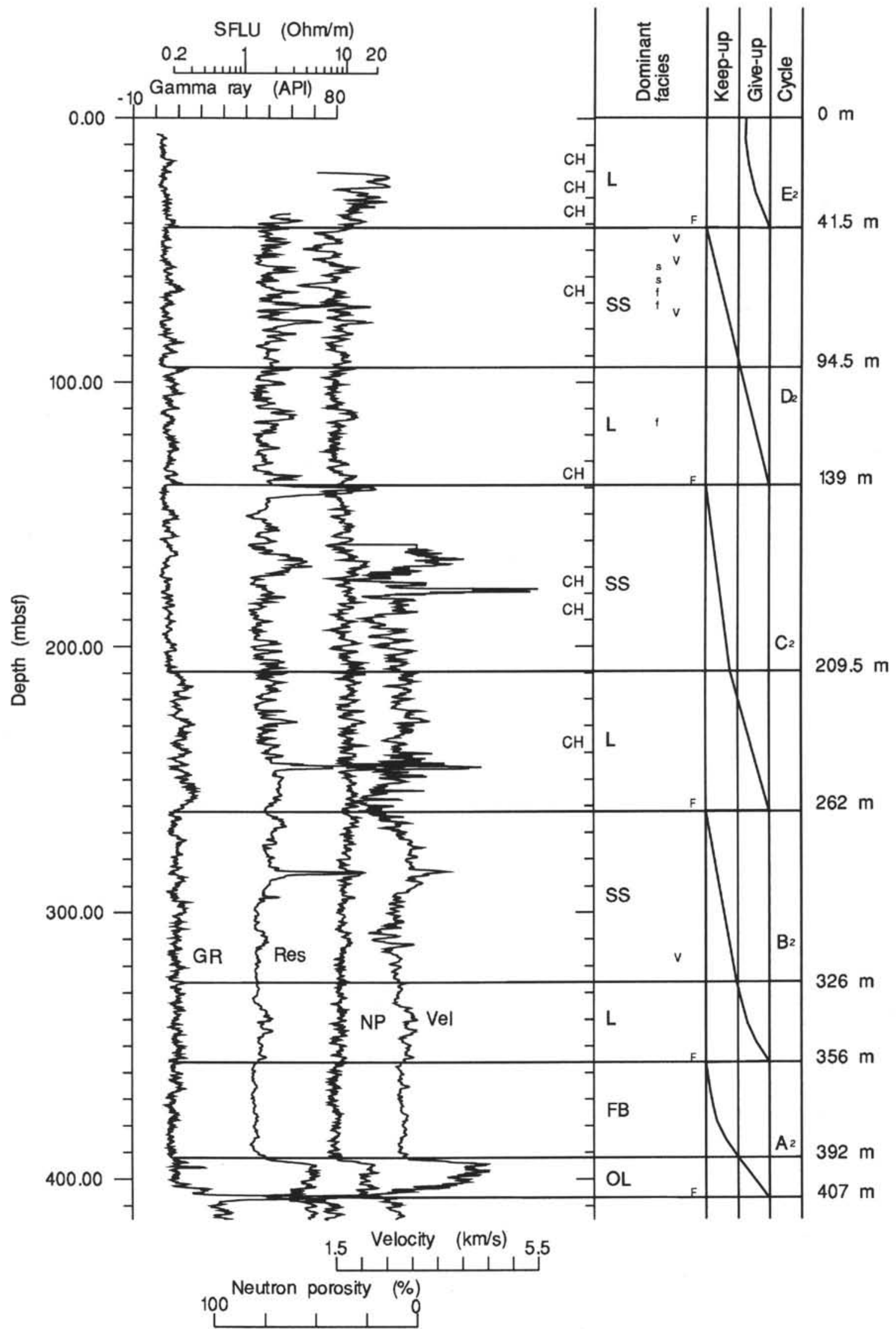

Figure 10. Cyclicity in the keep-up/give-up facies in the upper carbonate sequence (3.2-399.7 mbsf). Note that cycles are more than twice as thick as in the lower carbonate sequence. The uppermost cycle is represented only by the lagoonal hemicycle. Abbreviations as in Figure 9. 
concentration of $38.16 \mathrm{~mol} \% \mathrm{MgCO}_{3}$ (Samples 144-878A-75R-1, 68-72 cm; -75R-1, 38-41 cm; -75R-1, 20-23 cm; -75R-1, 5-10 cm; and $-74 \mathrm{R}-1,36-42 \mathrm{~cm}$ ) (Pl. 4, Fig. 6). The dolomite crystals have poikilotopic texture and enclose unabsorbed grains of micrite. The diagenetic environment for the dolomite is uncertain. However, from their occurrence near the base of the carbonate sequence and their poikilotopic texture, they are most probably of late diagenetic origin.

Applying the above-listed criteria, several diagenetic zones within the carbonate sequences can be established. The limestones at the base of the lower carbonate sequence (Cores 144-878A-78R to -73R, 731.7-674.2 mbsf) were initially cemented in the marine environment and were subsequently exposed to influences of freshwater phreatic diagenetic environment. Cores 144-878A-73R and -70R (645.2-654.9 mbsf) indicate incipient cementation in the marine environment that was followed by diagenesis in freshwater phreatic and vadose zones in Cores 144-878A-67R to -65R (625.9-597.1 mbsf). The limestones at the base of the upper carbonate sequence (Cores 144-878A-42M to -37M, 399.3-341.6 mbsf) were initially cemented in a marine phreatic zone, which was followed by diagenetic changes in the freshwater phreatic and vadose zone. Marine cements were noted in Cores 144-878 A-37M and -36M (351.2-331.9 mbsf) and - 14 to -10 (134.4-86.2 mbsf), whereas vadose zone diagenesis, using the above described criteria, affected limestones in Cores $144-878 \mathrm{~A}-36 \mathrm{M}$ to $-34 \mathrm{M}$ (341.6-312.6 mbsf). The diagenetic environment of Cores $144-878$ A-33M through -1R (302.9-0 mbsf) was variable, with both marine and freshwater phreatic diagenesis indices observed.

From Cores 144-878A-7R to $-1 \mathrm{R}$ ( $67-0 \mathrm{mbsf}$; the top of the platform) chalky limestone is prevalent. The limestone fragments recovered in Cores 144-878A-1R through -7R are chalkified peloid packstones and gastropod wackestones and rare, poorly lithified, friable grainstones (Figs. 4, 10). Unfortunately, the wireline logs, except for the gamma-ray $\log$, were not run in the uppermost $20 \mathrm{~m}$ of the drill hole. Thus, changes in porosity toward the top of the carbonate sequence are not documented. However, high drilling rates in this part of the sequence (Fig. 4) support increasing friability and thus, indirectly through lack of cementation, the increasing porosity in the uppermost $20 \mathrm{~m}$ of the carbonate sequence.

The surface of the carbonate cap of the guyot did not show any diagnostic karstification features, such as caliche profiles, speleothems, or rhizoliths (Esteban and Klappa, 1983; James and Choquette, 1984), which could result from short exposure time (juvenile karst; Grötch and Flügel, 1992). The guyot limestone surface is encrusted with $\mathrm{Fe} / \mathrm{Mn}$ oxyhydroxides, deposited during the $95 \mathrm{~m} . \mathrm{y}$. hiatus separating the Albian shallow-water limestones from the upper Miocene pelagic ooze (Bogdanov et al., this volume).

\section{Chalkification and Micritization}

Several chalkified limestone horizons are present within the lower and upper carbonate sequences (Figs. 9, 10). The degree of chalkification is most extensive in the uppermost part of the upper carbonate sequence (Cores 144-878A-1R through -7R). Chalkified limestones were also recovered by Cores $144-878 A-14 R,-15 R,-19 R,-21 R$, and $-25 \mathrm{M}$. The chalkification is recognizable in cores by the white color and the fine-grained texture, and by an obliteration of grain boundaries to the extent that they cannot be identified under the binocular microscope. Chalkified limestones are soft and easily scratched by fingernail. A characteristic feature is very high interparticle microporosity. Several different hypotheses explaining this phenomenon include diagenetic changes in the mixing zone, changes below the aragonite dissolution level and alteration in the cold-water environment, changes in closed geochemical system during burial, and vadose zone alteration (Friedman, 1983; Tucker and Wright, 1990).

An electron microprobe study of the chalkified limestones shows the micrite neomorphically altered into a dense framework of small crystals with patches of micropores concentrated in solution "channels" (Pl. 5, Fig. 1), giving a sievelike character to the rock (Pl. 5, Fig.
Table 2. Strontium and magnesium concentration in Lower Cretaceous meteoric and marine calcite cements at MIT Guyot and Anewetak Atoll.

\begin{tabular}{lrcc}
\hline \multicolumn{1}{c}{ Description } & $N$ & $\begin{array}{c}\text { Strontium } \\
\text { concentration } \\
\text { (ppm) }\end{array}$ & $\begin{array}{c}\text { Magnesium } \\
\text { concentration } \\
\left(\mathrm{mol} \% \mathrm{MgCO}_{3}\right)\end{array}$ \\
\hline Sparry cements & 35 & $(146)$ & \\
Radiaxial-fibrous & 4 & 405 & 1.29 \\
Bladed overgrowth & 4 & $435(540)$ & $1.22(1.00)$ \\
Equant, void fill & 6 & $382(490)$ & $1.22(0.84)$ \\
Short, equant rim & 4 & $702(900)$ & $1.31(0.96)$ \\
Coarse bladed & 4 & $390(470)$ & $1.15(0.68)$ \\
Echinoid overgrowth & 6 & $356(770)$ & $1.01(1.72)$ \\
Micrite rim on peloid & 3 & 480 & 1.20 \\
Recrystalized (chalky) micrite & 4 & 370 & 1.15 \\
Recrystalized peloids in a void & 4 & 375 & 1.22 \\
Dolomite rhombs & 2 & & 38.16 \\
\hline
\end{tabular}

Notes: Data in parentheses after Saller and Moore (1991). $N=$ number of observations. Each observation includes five separate spot analyses. Samples analyzed: 144 $878 \mathrm{~A}-76 \mathrm{R}-1,55-59 \mathrm{~cm}$, large equant spar $(180 \mu \mathrm{m})$ in interparticle voids, syntaxial rim on echinoids, outer surface of silt-sized peloids infilling some of the interparticle voids, short equant rim cement: $144-878 \mathrm{~A}-75 \mathrm{R}-1,68-72 \mathrm{~cm}$, poikilotopic dolomite crystals; 144-878 A-30R-1, 48-53 cm, syntaxial overgrowth rim on echinoid; 144-878A-26R-1, 8-12 cm, and -9R-1, 36-38 cm, impurities ocluded basal part of the palisade sparry calcite rim with ghost fibrous texture; clear terminations of bladed sparry calcite of the palisade rim, coarse equant sparry calcite replacing bioclasts; coarse randomly oriented equant, post palisade rim sparry calcite crystals growing into interparticle voids; 144-878A-9R-1, 22-27 cm, short equant sparry calcite rims, coarse equant spary calcite infilling bioclast molds; $144-878 \mathrm{~A}$ IR-CC, $18-21 \mathrm{~cm}$, silt-sized peloids geopetally infilling burrow trails, micrite matrix, silt-sized peloids within the micrite matrix.

2). Only some of the limestone horizons are chalkified, which argues against recrystallization during burial or below aragonite dissolution level alteration. We interpret the chalkified horizons as probable surface-weathering phenomena, with alteration occurring in the vadose diagenetic zone. The process of chalkification has to be differentiated from micritization, which in Site 878 limestones is ubiquitous (Pl. 1, Fig. 1). Micritization results from fungi and endolithic algae borings of the rims of the skeletal grains (Bathurst, 1971), a process very different from that of chalkification. Micritization leads to the development of micrite envelopes rimming skeletal grains, if intensive enough, it may also result in complete replacement of skeletal grain by micrite. However, these two processes are petrographically distinguishable. Micritization produces grains that show various intensity of development of micrite envelops to complete grain alteration, all occurring side by side. In contrast, chalkification results in wholerock micritization, with all grains replaced by micrite.

\section{HISTORY OF THE CARBONATE BUILDUP}

The description and diagenetic study of limestone cores and interpretation of wireline logs, including the dipmeter log for the upper carbonate sequence, allow us to reconstruct the depositional history of the carbonate buildup using general models of modern atoll and carbonate bank construction as well as to investigate relative sea-level changes and the drowning of MIT Guyot.

The thick, well-sorted grainstone facies that overlies the volcanic substrate and which was also deposited during a brief period before and after volcanic eruption, is interpreted to represent the fringing carbonate bank stage. The atoll-like stage of the carbonate buildup, which occurs between the upper and lower fringing carbonate phases of the lower carbonate sequence and above the basal fringing carbonate bank phase of the upper carbonate sequence, comprises lithologically variable beds dominated by "carbonate sand" facies. The relatively rare occurrence of carbonate mudstone, which wireline logs indicate to be beds $0.5-3 \mathrm{~m}$ thick, suggests the generally shallow lagoon, which was rapidly infilled at its margin by carbonate sands of the sand shoal facies. This interpretation agrees with the predominantly shallow (30-50 m) depth of many modern atoll lagoons. Some of the carbonate sands at Site 878 coarsen upward, whereas others fine upward, which is interpreted as the response to changes of 
hydrodynamic conditions and relative sea-level changes. The upward coarsening may result from progradation of the sands into the lagoon during standstill. Those parts of the carbonate sequence that are dominated by grainstone and packstone beds, without a recognizable vertical change in the grain size, are considered to represent sand shoals deposited during the keep-up (buildup) phase, when guyot subsidence and carbonate production were balanced.

The dipmeter logs, which are available only for the upper carbonate sequence, show inclination within the grainstone beds of about 10 degrees; the dominant dip direction is southwest-northeast. Above 140 mbsf in the upper carbonate sequence, dips toward north-northeast become more common. Considering the orientation of the guyot, the dipmeter data indicate that most of the grainstones were deposited from longshore currents that followed the configuration of the atoll. We suggest that the direction of current flow was governed by the prevailing wind orientation, dominated by southeast trade winds. The direction changed to a more northerly direction before the end of carbonate buildup construction, which agrees with the mid-Cretaceous ocean-surface-circulation modeling by Barron and Peterson (1990).

The presence of pebbly beds and fragments of biohermal boundstone with corals, stromatoporoids, rudists, and calcareous sponges encrusted by algae and foraminifers indicates the presence of bioconstructions either rimming the sand flats or colonizing the shallow lagoon similarly to modern patch reefs. Because of the poor core recovery, the presence of bioconstruction facies, even though very probable, remains unproven.

\section{Relative Sea-level Changes and Eustasy}

Three principal construction phases can be recognized in carbonate buildups: catch-up, keep-up, and give-up (Kendall and Schlager, 1981; Davies and Montaggioni, 1985). The catch-up phase (regressive stage) is a period of shallowing when the carbonate deposits build toward sea level, which shows as an upward-coarsening trend of sedimentary deposition in vertical profile. The keep-up phase represents equilibrium conditions when depositional conditions are maintained for a prolonged period without any significant vertical change in facies composition. Such a phase can be represented by the occurrence of multistory, amalgamated grainstones. The give-up phase (transgressive stage) is a deepening or flooding trend represented by fining-upward beds and carbonate mud deposits. Interpretations of wireline logs at Hole 878 A indicate major changes in the vertical distribution of lithofacies, which can be related to the above phases, particularly when represented by strata several tens of meters thick. The interpretation is schematically shown in Figures 9 and 10 as a two-phase system: the catch-up/keepup phase and the give-up phase. As these figures show, the phases alteration is cyclic. The shoaling-upward cycle, as defined here, is initiated by flooding and deepening of the lagoon and culminates in grainstone deposition during shoaling, or even in the development of an "emersion surface." Fenestral fabric, iron staining, and vadose cementation were noted near the top of some of the cycles (Fig. 10), suggesting occasional building of the top of the beds into the intertidal zone. However, clear exposure surfaces were not identified in the cores, which is most probably an artifact of poor core recovery.

Application of the keep-up/give-up architecture to the carbonate deposition at MIT Guyot allows us to recognize three depositional cycles within the lower carbonate sequence: cycle $\mathrm{A}_{1}$ ( $38 \mathrm{~m}$ thick), $\mathrm{B}_{1}$ (38.5 m), and $C_{1}(47.5 \mathrm{~m})$ (Fig. 9). The construction of the lower carbonate sequence was affected by volcanic eruption that caused partial destruction of the upper part of the cycle $C_{1}$. Four and one-half cycles, with the last incomplete cycle represented by only the lagoonal hemicycle, can be differentiated in the upper carbonate sequence (Fig. 10): cycle $A_{2}$ (51 m thick), $B_{2}(94 m), C_{2}(123 m), D_{2}(97.5 m)$, and $E_{2}$ $(41.5 \mathrm{~m})$. These cycles are more than twice as thick as the cycles in the lower carbonate sequence, which reflects differences in the rate of subsidence. We suggest that thermal cooling following the volcanic event caused the increased rate of subsidence.
Another possible cause of the cyclic alteration of the facies at MIT Guyot could be the lateral facies shifts. However, Site 878 was located in the lagoonal part of the "atoll" and the major lithologic changes are on a scale of 38 to $120 \mathrm{~m}$. MIT Guyot, at places, is less than $2 \mathrm{~km}$ wide. The alteration could not have resulted from differential subsidence or lateral facies shifts because of space constriction for the latter. Relative sea level changes thus provide the best explanation of the observed cyclicity.

Three give-up phases affected construction of the lower carbonate sequence, and five give-up phases affected the upper sequence. The biostratigraphic study of the carbonates (Fig. 5) documented an early Aptian age for the basal part of the lower carbonate sequence and a late Albian age for the upper carbonate sequence. Haq et al. (1988) postulated the existence of three third-order eustatic cycles during the Aptian and seven cycles in the Albian. The occurrence of three flooding periods during the Aptian at MIT Guyot is in reasonably good agreement with Haq et al.'s interpretation and would constrain the base of the carbonate strata to the cycle LZB-3.5 and the volcanic event to cycle LZB-4.2. The presence of five periods of flooding in the upper carbonate sequence could indicate that the building of the shallow-water carbonates continued into the late Albian (approximately Ticinella primula Zone, cycle UZA-1.5).

\section{MIT Guyot Drowning}

McNutt et al. (1990) suggested that the regional tectonic model alone cannot explain drowning because subsidence rates during cooling of the Pacific plate are at least one order of magnitude lower than the potential growth rate of carbonate platforms (Schlager, 1981). Grötsch and Flügel (1992) interpreted the drowning of guyots in the northwestern Pacific to be climatically controlled, with climate disturbance triggering short-term cooling and late Albian drowning of guyots. Winterer et al. (1993) also suggested that drowning of guyots was a late Albian event, with guyots uplifted during the Albian and submerged in the Turonian, when pelagic sediment began to accumulate on the guyot summits.

The drilling of sunken guyots during Leg 144 did not provide support for most of the above hypotheses (Premoli Silva, Haggerty, Rack, et al., 1993). Drilling of the south-north transect (see site map preceding title page) across northwestern Pacific demonstrated that the cessation of shallow-water carbonate deposition was diachronic, with some of the guyots drowned in the late Albian, others in the Maastrichtian and some even in the Eocene. Erba et al. (1993) related the drowning of northwestern Pacific guyots to the transport of the guyots by plate motion into the high-nutrient and high-productivity equatorial zone. The recovered cores from the top of the MIT Guyot do not provide evidence that this was the case.

However, the study of carbonates from the top of the MIT Guyot provided some information about the drowning process. The sediment forming the surface of the shallow-water carbonate buildup at Hole $878 \mathrm{~A}$ is a lagoonal deposit, which lacks any indication of the imminent cessation of carbonate deposition. On a larger scale, the depositional cyclicity shown in Figure 10 also does not indicate a change in depositional trend. The presence of chalkified lagoonal deposits at the top of the guyot in the overall context of the guyot's carbonate buildup development is reasonable evidence to suggest subaerial exposure of the guyot surface by unspecified regional tectonic event. The closest modern analog could be Makatea Island, located $245 \mathrm{~km}$ northeast of Tahiti. This island, constructed by a carbonate having facies similar to an atoll, is of Miocene to late Pleistocene age and elevated 60-75 m above sea level (Montaggioni et al., 1985). The uplift of Makatea Island is thought to have resulted from the isostatic response of the lithosphere to the load of the nearby Tahiti volcanic complex (McNutt and Menard, 1978). The central part of the island is represented by chalkified lagoonal deposits, a comparable lithofacies and diagenetic alteration to Site 878 . 


\section{SUMMARY}

Drilling in Hole 878A on the MIT Guyot in the northwestern Pacific Ocean penetrated $719 \mathrm{~m}$ of shallow-water carbonate buildup with a zone of volcanic tephra mixed with limestone fragments separating the buildup into a lower 118-m-thick carbonate sequence and upper 397-m-thick carbonate sequence.

The carbonate strata are dominated by grainstone and packstone facies with $13 \%$ wackestone and mudstone and $5.5 \%$ bioconstructed carbonate or their debris. The lack of open-marine biota, such as planktonic foraminifers and bryozoa, and the dominance of restricted microfauna support deposition in the lagoonal environment of an atoll-like structure.

The architecture and composition of the sediments indicate that fringing carbonate bank/reef facies overlie the volcanic substrate and also precede and immediately follow the volcanic eruption, which destroyed part of the lower carbonate sequence. Between these two fringing carbonate bank/reef periods and after the volcanic event, deposition occurred in an atoll-like environment. The grainstone and packstone were deposited predominantly in a sand shoal environment rimming the "atoll" and occasionally prograded into the lagoon. The skeletal wackestones and biomicrites were deposited in the deep lagoon.

Bioconstructed limestone facies are rare, and no features that could be interpreted as reefs were found in cores, although the occurrence of small size bioconstructions is indicated by the wireline logs. In the lower carbonate sequence, which is of Aptian age, corals are relatively common. This contrasts with the upper carbonate sequence, which is mainly of Albian age, where the bioconstructed limestone deposits more frequently contain rudist debris, with some stromatoporoids. Corals occur only sporadically.

Carbonate cement stratigraphy documents periodic marine cementation with deposited sediments diagenetically modified in a freshwater and marine phreatic environments. Conclusions from the cement stratigraphy are supported by low-magnesium concentration in cements $\left(<1.4 \mathrm{~mol} \% \mathrm{MgCO}_{3}\right)$, lack of iron, and low strontium content, suggesting diagenetic modification of the deposited carbonates in a freshwater phreatic zone.

Preservation of up to $40 \%$ of the primary porosity in shallowwater carbonates over a time period of 100 m.y. documents retardation of the diagenetic process when the carbonates were submerged into cold, deep-ocean water environment.

The extensive chalkification noted at several levels in the carbonate buildup results from neomorphism of micrite and its concurrent dissolution. The presence of dissolution channels in altered micrite indicate that chalkification occurred in the vadose zone (Friedman, 1983). If this was correct, then the increased chalkification toward the top of the guyot would support the van Waasbergen and Winterer (1993) hypothesis of an extended period of karstification of the top of the MIT Guyot before its drowning.

The alternating keep-up and give-up phases in carbonate deposition, as interpreted from E-log and core data studies, indicate seven deepening periods during the MIT Guyot atoll-like buildup. These periods are interpreted as correlative to the third-order eustatic cycles of Haq et al. (1988), with the lowest depositional sequence correlatable to Cycle LZB-3.5 and the uppermost to the Cycle LZA-1.5. If this correlation is valid, then it would indicate that the volcanic event, which destroyed part of the lower carbonate sequence, occurred during the late Aptian (Cycle LZB-4.2), in a time window of about 106-104 Ma. From the same evidence, the third-order cyclicity in the upper carbonate sequence indicate that the carbonate buildup construction ceased at about $100 \mathrm{~m}$.y. Owing to the poor core recovery and the drilling of only a single hole, no data about the magnitude of relative sea-level changes can be derived from MIT Guyot.

Drilling of drowned guyots in the northwestern Pacific Ocean during Leg 144 documented that drowning occurred at different guyots at different times ranging from Albian to Eocene, and thus it is not a synchronous event. Study of carbonate deposits at MIT Guyot leads us to the interpretation that the cessation of carbonate deposition was a rapid event, culminating in subaerial exposure of the surface of the guyot. The best explanation for such an event is regional tectonic uplift. The cause of this regional emergence is unknown.

\section{ACKNOWLEDGMENTS}

The authors acknowledge the benefit of the scientific staff of Leg 144 for valuable discussions and for providing some of the petrographic data for Table 1. Paul Lake assisted with microphotography and thin-section preparation. Frank Thomas, Nelly Koziel, and Gary Grant were helpful with final preparation of the manuscript. Zehui Huang provided results of mathematical testing of the cyclicity at Site 878. We thank D.B. Clarke and R. MacKay for the use of the Dalhousie University electron microprobe laboratory and for assistance. The manuscript was improved by reviews of John Wade, Eric Flügel, and an anonymous reviewer. This is Geological Survey of Canada Contribution No. 14894.

\section{REFERENCES}

Aissaoui, D.M., and Purser, B.H., 1983. Nature and origin of internal sediments in Jurassic limestones of Burgundy (France) and Fnoud (Algeria) Sedimentology, 30:273-283.

Asquith, R.P., 1979. Subsurface Carbonate Depositional Models: A Concise Review: Tulsa (PennWell).

Barnes, D.J. (Ed.), 1983. Prospectives on Coral Reefs. Australian Inst. Mar. Sci.

Barron, E.J., and Peterson, W.H., 1990. Mid-Cretaceous ocean circulation: results from model sensitivity studies. Paleoceanograph: 5:319-337.

Basham, W.H.M., and Dorfman, M.H., 1983. Facies characterization of carbonates by use of well logs, Sligo Formation (lower Cretaceous), South Texas. SWPLA 24th Logging Symp., 1-17.

Bathurst, R.G.C., 1971. Carbonate Sediments and Their Diagenesis: Amsterdam (Elsevier), Dev. in Sedimentol. Ser., 12.

Budd, D.A., and Land, L.S., 1990. Geochemical imprint of meteoric diagenesis in Holocene ooid sands, Schooner Cays, Bahamas: correlation of calcite cement geochemistry with extant groundwaters. J. Sediment. Petrol., 60:361-378.

Chevalier, J.P., 1973. Geomorphology and geology of coral reefs in French Polynesia. In Jones, O.A., and Endean, R.E. (Eds.), Biology and Geology of Coral Reefs (Vol. 1): Geology: New York (Academic Press), 113-141.

Crough, S.T., 1984. Seamounts as records of hot-spot epeirogeny. Geol. Soc. Am. Bull., 95:3-8.

Davies, P.J., and Montaggioni, L., 1985. Reef growth and sea-level change: the environmental signature. Proc. 5th Int. Coral Reef Congr., 3:477-511.

Dorfman, M.H., Newey, J.-J., and Coates, G.R., 1990. New techniques in lithofacies determination and permeability prediction in carbonates using well logs. In Hurst, A., Lovell, M.A., and Morton, A.C. (Eds.), Geological Applications of Wireline Logs. Geol. Soc. Spec. Publ. London, 48:113-120.

Erba, E., Bergersen, D.D., Larson, R.L., Lincoln, J.M., Nakanishi, M., and ODP Leg 144 Scientific Party, 1993. Paleolatitude and vertical subsidence histories of ODP Leg 144 guyots. Eos, 74:353.

Esteban, M., and Klappa, C.F., 1983. Subaerial exposure environment. In Scholle, P.A., Bebout, D.G., and Moore, C.H. (Eds.), Carbonate Depositional Environments. AAPG Mem., 33:1-54.

Friedman, G.M., 1983. Reefs and porosity: examples from the Indonesian Archipelago. SEAPEX Proc., 6:35-40.

Friedman, G.M., Sanders, J.E., and Kopaska-Merkel, D.C., 1992. Principles of Sedimentary Deposits: New York (Macmillan).

Gili, E., 1993. Facies and geometry of Les Collades de Basturs carbonate platform, Upper Cretaceous, South-Central Pyrenees. In Simo, J.A.T. Scott, R.W., and Masse, J.-P. (Eds.), Cretaceous Carbonate Platforms. AAPG Mem., 56:343-352.

Goter, E.R., and Friedman, G.M., 1988. Deposition and diagenesis of the windward reef of Enewetak Atoll. Carbon. Evap., 2:157-180.

\footnotetext{
Abbreviations for names of organizations and publications in ODP reference lists follow the style given in Chemical Abstracts Service Source Index (published by American Chemical Society)
} 
Grötsch, J., and Flügel, E., 1992. Facies of sunken Early Cretaceous atoll reefs and their capping late Albian drowning succession (northwestern Pacific). Facies, 27:153-174.

Haq, B.U., Hardenbol, J., and Vail, P.R., 1988. Mesozoic and Cenozoic chronostratigraphy and cycles of sea-level change. In Wilgus, C.K., Hastings, B.S., Kendall, C.G.St.C., Posamentier, H.W., Ross, C.A., and Van Wagoner, J.C. (Eds.), Sea-Level Changes-An Integrated Approach. Spec. Publ.-Soc. Econ. Paleontol. Mineral., 42:72-108.

Hess, H.H., 1946. Drowned ancient islands of the Pacific basin. Am. J. Sci., 244:772-791.

James, N.P., and Choquette, P.W., 1983. Diagenesis 6: Limestones: the seafloor diagenetic environment. Geosci. Can., 10:162-179.

, 1984. Diagenesis 9: Limestones-the meteoritic diagenetic environment. Geosci. Can., 11:161-194.

Jansa, L.F., Pratt, B.R., and Dromart, G., 1989. Deep water thrombolite mounds from the Upper Jurassic of offshore Nova Scotia. In Geldsetzer H.H.J., James, N.P., and Tebbutt, G.E. (Eds.), Reefs, Canada and Adjacent Areas. Mem.-Can. Soc. Pet. Geol., 13:725-735.

Jones, O.A., and Endean, R.E. (Eds.), 1973. Biology and Geology of Coral Reefs (Vol. 1): Geology: New York (Academic Press).

Kamon, K., and Dorfman, M.H., 1986. Identification of carbonate depositional texture from well-log response, West Seminole Field, Gaines Co., Texas. PB/SEPM Publ., 86-26:75-77.

Keith, B.D., and Pittman, E.D., 1983. Bimodal porosity in an oolitic reservoir: effect on productivity and log response, Rodessa Limestone (Lower Cretaceous), East Texas. AAPG Bull., 67:1391-1399.

Kendall, C.G.St.C., and Schlager, W., 1981. Carbonates and relative changes in sea level. In Cita, M.B., and Ryan, W.B.F. (Eds.), Carbonate Platforms of the Passive-type Continental Margins, Present and Past. Mar. Geol., 44:181-212.

Lincoln, J.M., and Schlanger, S.O., 1991. Atoll stratigraphy as a record of sea level change-problems and prospects. J. Geophys. Res., 96:6727-6752.

Longman, M.W., 1980. Carbonate diagenetic textures from nearsurface diagenetic environments. AAPG Bull., 64:461-487.

Marshall, J.F., and Jacobson, G., 1985. Holocene growth of a mid-Pacific atoll: Tarawa, Kiribiti. Coral Reefs, 4:11-17.

Matthews, J.L., Heezen, B.C., Catalano, R., Coogan, A., Tharp, M., Natland, J., and Rawson, M., 1974. Cretaceous drowning of reefs on Mid-Pacific and Japanese guyots. Science, 184:462-464.

McNutt, M.K., and Menard, H.W., 1978. Lithospheric flexure and uplifted atolls. J. Geophys. Res., 83:1206-1212.

McNutt, M.K., Winterer, E.L., Sager, W.W., Natland, J.H., and Ito, G., 1990. The Darwin Rise: a Cretaceous superswell? Geophys. Res. Lett., 17:11011104.

Montaggioni, L.F., Richard, G., Bourrouilh-Le Jan, F., Gabrie G., Humbert, L., Monteforte, M., Naim, O., Payri, C., and Salvat, B., 1985. Geology and marine biology of Makatea, an uplifted atoll, Tuamoty Archipelago, Central Pacific Ocean. J. Coastal Res., 1:165-171.

Moore, C.H., 1989. Carbonate Diagenesis and Porosity: Amsterdam (Elsevier), Devl. in Sedimentol. Ser., 46.

Nakanishi, M., Tamaki, K., and Kobayashi, K., 1992. Magnetic anomaly lineations from Late Jurassic to Early Cretaceous in the west-central Pacific Ocean. Geophys. J. Int., 109:701-719.

Premoli Silva, I., Haggerty, J., Rack, F., et al., 1993. Proc. ODP, Init. Repts., 144: College Station, TX (Ocean Drilling Program).
Quinn, T.M., 1991. Meteoric diagenesis of post-Miocene limestones on Enewetak Atoll. J. Sediment. Petrol., 61:681-703.

Sager, W.W., Winterer, E.L., Firth, J.V., et al., 1993. Proc. ODP, Init. Repts., 143: College Station, TX (Ocean Drilling Program).

Saller, A.H., and Moore, C.H., 1991. Geochemistry of meteoritic calcite cement in some Pleistocene limestones. Sedimentology, 38:601-621.

Schlager, W., 1981. The paradox of drowned reefs and carbonate platforms. Geol. Soc. Am. Bull., 92:197-211.

Schlanger, S.O., 1963. Subsurface geology of Eniwetak Atoll. Geol. Surv. Prof. Pap. U.S., 260-BB:991-1066.

Schroeder, J.H., and Purser, B.H. (Eds.), 1986. Reef Diagenesis: Berlin (Springer-Verlag).

Scoffin, T.P., Stoddart, D.R., Tudhope, A.W., and Woodroffe, C., 1985. Rhodoliths and coralliths of Murin Lagoon, Raratonga, Cook Islands. Coral Reefs, 4:71-80.

Scott, R.W., 1988. Evolution of Late Jurassic and Early Cretaceous reef biotas. Palaios, 3:184-193.

Steinen, R.P., and Matthews, R.K., 1973. Phreatic versus vadose diagenesis: stratigraphy and mineralogy of a cored bore hole on Barbados, West Indies. J. Sediment. Petrol., 43:1012-1021.

Stowe, I., and Hock, M., 1988. Facies analysis and diagenesis from well logs in the Zechstain carbonates of northern Germany. SWPLA 29th Annu. Logging Symp., 1-25.

Tucker, M.E., and Wright, P.V., 1990. Carbonate Sedimentology: Oxford (Blackwell Sci. Publ.).

van Waasbergen, R.J., and Winterer, E.L., 1993. Summit geomorphology of Western Pacific guyots. In Pringle, M.S., Sager, W.W., Sliter, W.V., and Stein, S. (Eds.), The Mesozoic Pacific: Geology, Tectonics, and Volcanism. Geophys. Monogr., Am. Geophys. Union, 77:335-366.

Veron, J.E.N., 1986. Corals of Australia and the Indo-Pacific: Sydney (Angus and Robertson).

Wardlaw, B.R., and Henry, T.W., 1986. Physical stratigraphic framework. In Henry, T.W., and Wardlaw, B.R. (Eds.), Pacific Enewetak Atoll Crater Exploration (PEACE) Program, Enewetak, Republic of the Marshall Islands. Part 3: Stratigraphic Analysis and Other Geologic and Geophysical Studies in Vicinity of KOA and OAK Craters. Open-File Rep.-U.S. Geol. Surv., 86-555:1-26.

Wheeler, W.W., and Aharon, P., 1991. Mid-oceanic carbonate platforms as oceanic dipsticks. Coral Reefs, 10:101-114.

Winterer, E.L., and Metzler, C.V., 1984. Origin and subsidence of guyots in Mid-Pacific Mountains. J. Geophys. Res., 89:9969-9979.

Winterer, E.L., Natland, J.H., van Waasbergen, R.J., Duncan, R.A., McNutt, M.K., Wolfe, C.J., Premoli Silva, I., Sager, W.W., and Sliter, W.V., 1993. Cretaceous guyots in the Northwest Pacific: an overview of their geology and geophysics. In Pringle, M.S., Sager, W.W., Sliter, W.V., and Stein, S. (Eds.), The Mesozoic Pacific: Geology, Tectonics, and Volcanism. Geophys. Monogr., Am. Geophys. Union, 77:307-334.

Wolfe, C.J., and McNutt, M.K., 1991. Compensation of Cretaceous seamounts of the Darwin Rise, northwest Pacific. J. Geophys. Res., 96:2363-2373.

\footnotetext{
Date of initial receipt: 8 February 1994

Date of acceptance: 19 September 1994

Ms 144SR-039
} 


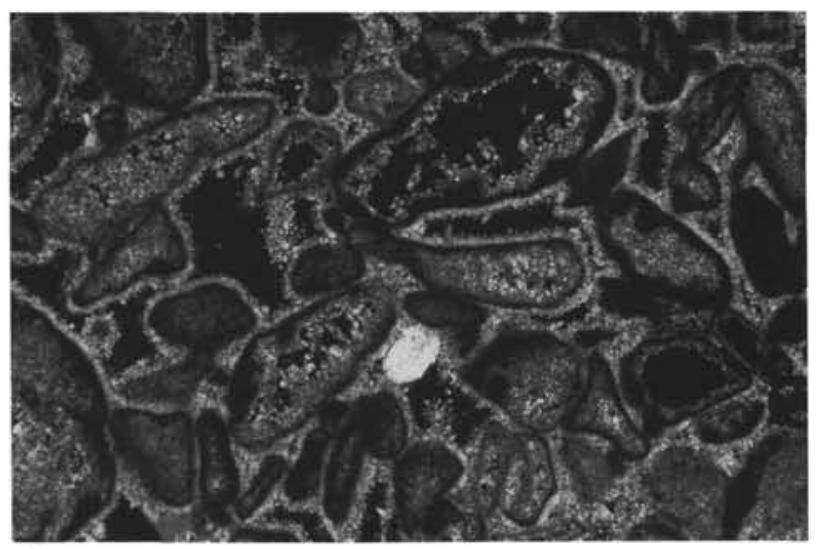

1

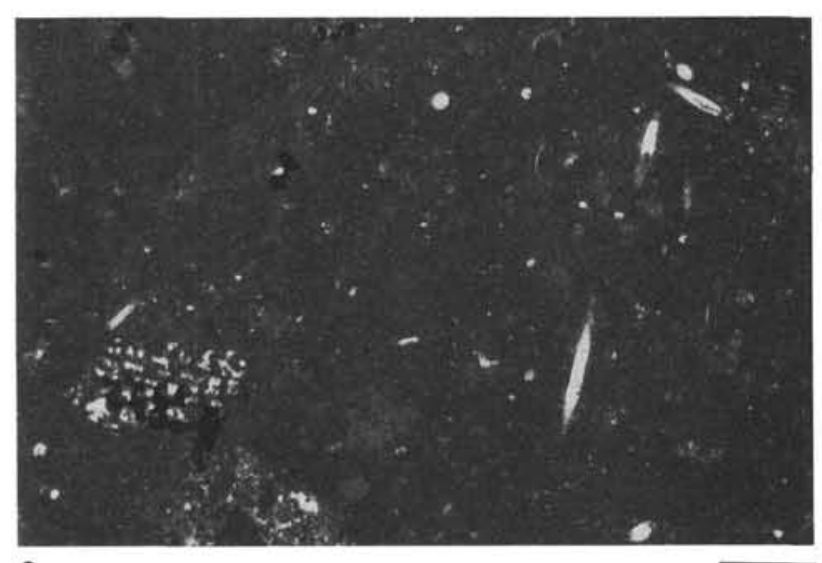

3

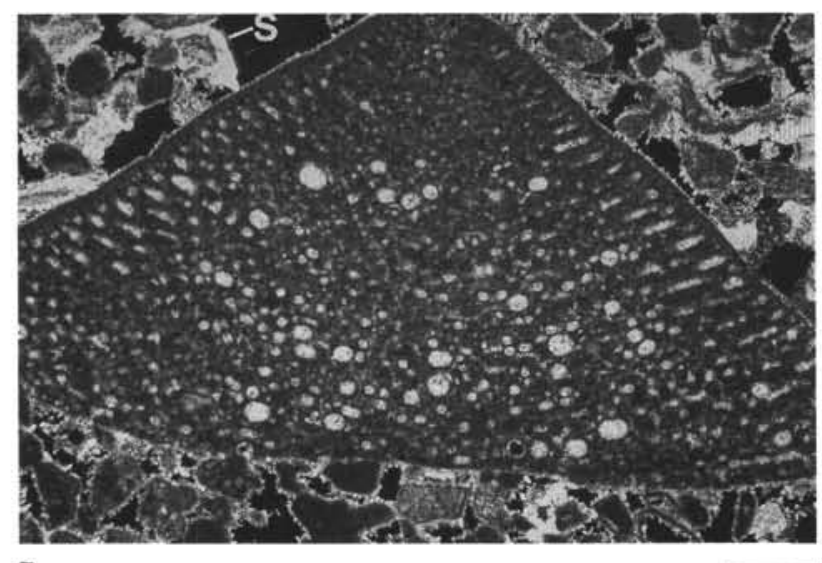
5

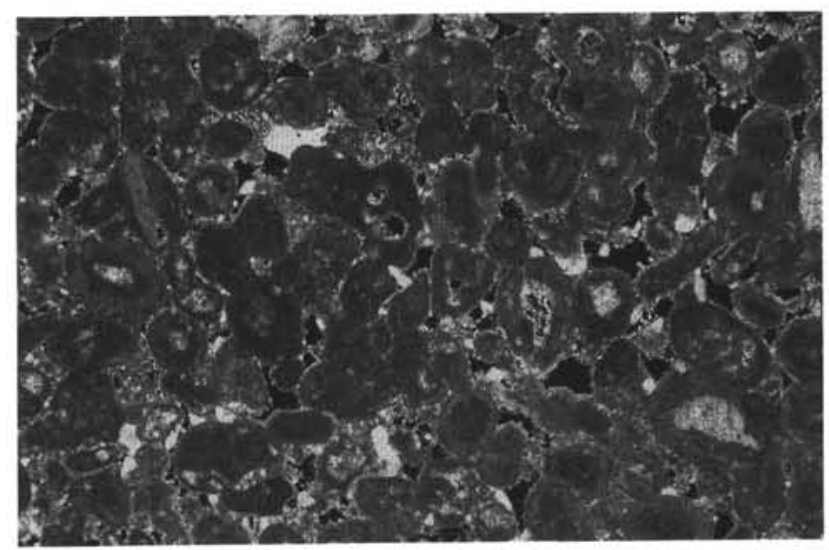

2

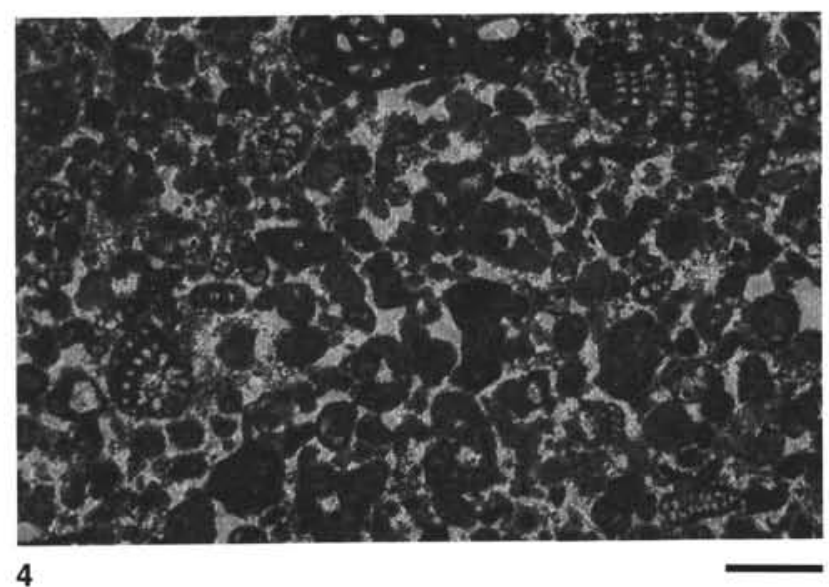

4

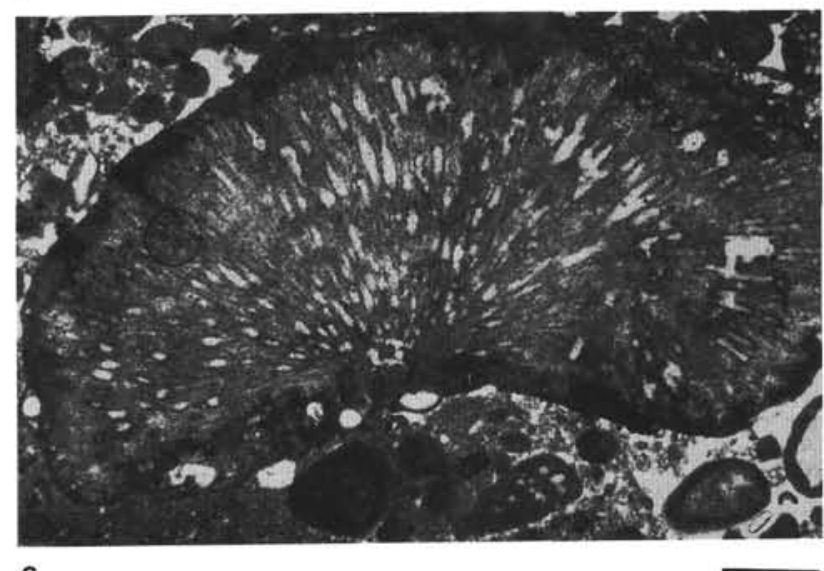

6

Plate 1. Site 878 microfacies. 1. Skeletal grainstone composed of worn debris (mainly pelecypod). The high Mg-calcite or aragonite shell was leached out and only micrite envelopes remain, with voids partially infilled by low $\mathrm{Mg}$ equant and bladed sparry calcite. Large, rare, rhombic calcite crystals were precipitated in the interparticle voids. Grains have been cemented by palisade rim cement (lower carbonate sequence, subfacies 1; fringing carbonate bank). Sample 144-878A-78R-1, 40-43 cm; crossed nicols; scale bar $=0.4 \mathrm{~mm}$. 2. Oolite-skeletal grainstone (lower carbonate sequence, subfacies 2; fringing carbonate bank). The oolites have mostly micrite, less skeletal fragments as nuclei. Oolite rims show variable degrees of micritization. Note the high interparticle porosity at the right side of the microphotograph. In contrast, the pores were mostly infilled by cement on the lower left, demonstrating the inhomogeneity in cementation. $\mathrm{E}=$ large equant $\mathrm{x}$-calcite. Sample 144-878A-72R-1, $18-22 \mathrm{~cm}$; crossed nicols; scale bar $=0.4 \mathrm{~mm}$. 3. Biomicrite with silt-size peloids, rare ostracode shells, and small benthic foraminifers (upper carbonate sequence; deep lagoon facies). The burrow trail has been infilled by pellets. Sample 144-878A-14R-1, 10-14 cm; transmitted light; scale bar $=0.4 \mathrm{~mm}$. 4. Grainstone with a chalky, friable, foraminifer-peloid composition. The grainstone is well sorted and composed of subangular, totally micritized skeletal debris. Only small benthic foraminifers are recognizable, represented by Cuenolina, miliolids, and small biserial benthic foraminifers. Grains are poorly cemented by micrite at some grain boundaries (upper carbonate sequence; carbonate sand shoal facies). Sample 144-878A-22M-1,3-4 cm; ordinary light; scale bar $=0.01 \mathrm{~mm}$. 5. Mesoorbitolina texana in peloid-skeletal grainstone. Note the high interparticle porosity, syntaxial overgrowth on echinoderm debris (S), and short-bladed rim cement. Sample 144-878A-30M-1, 29 cm; crossed nicols; scale $\mathrm{bar}=0.2 \mathrm{~mm}$. 6. Codiaceae algae (Cayeuxia) in foraminifer-coated grains-peloidal grainstone, with patches of a wackestone. Algal cushions have a micrite envelope. Sample 144-878A-2R-1, $25 \mathrm{~cm}$; transmitted light; scale bar $=0.01 \mathrm{~mm}$. 


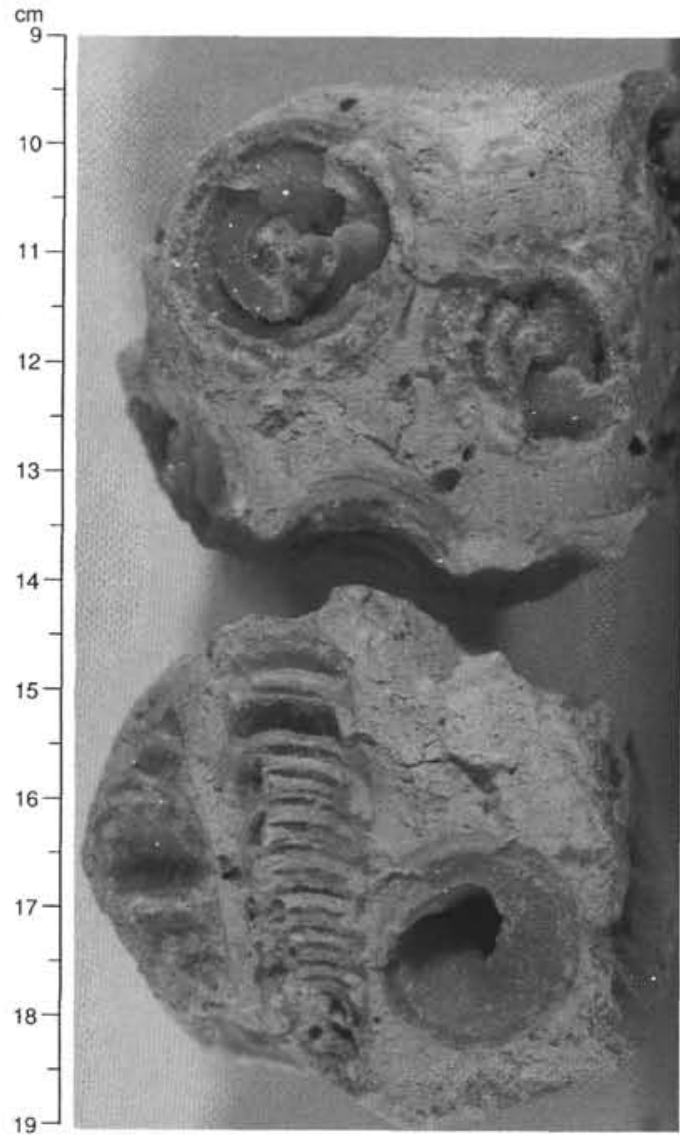

1

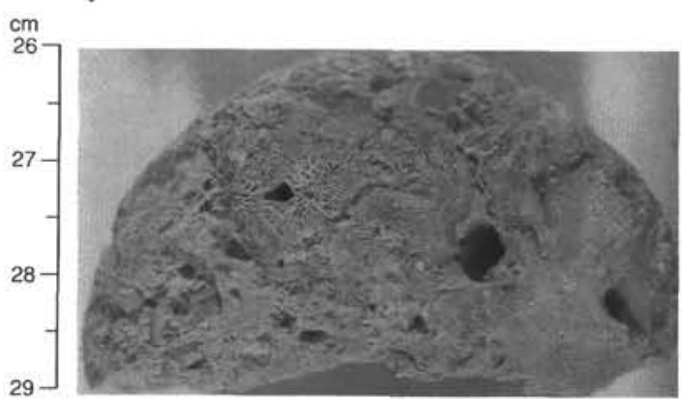

2

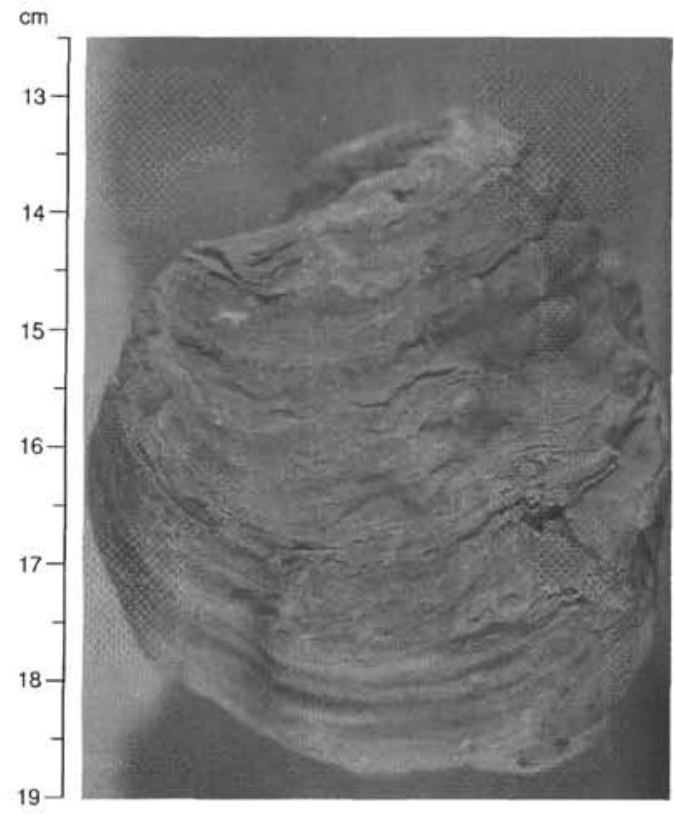

3

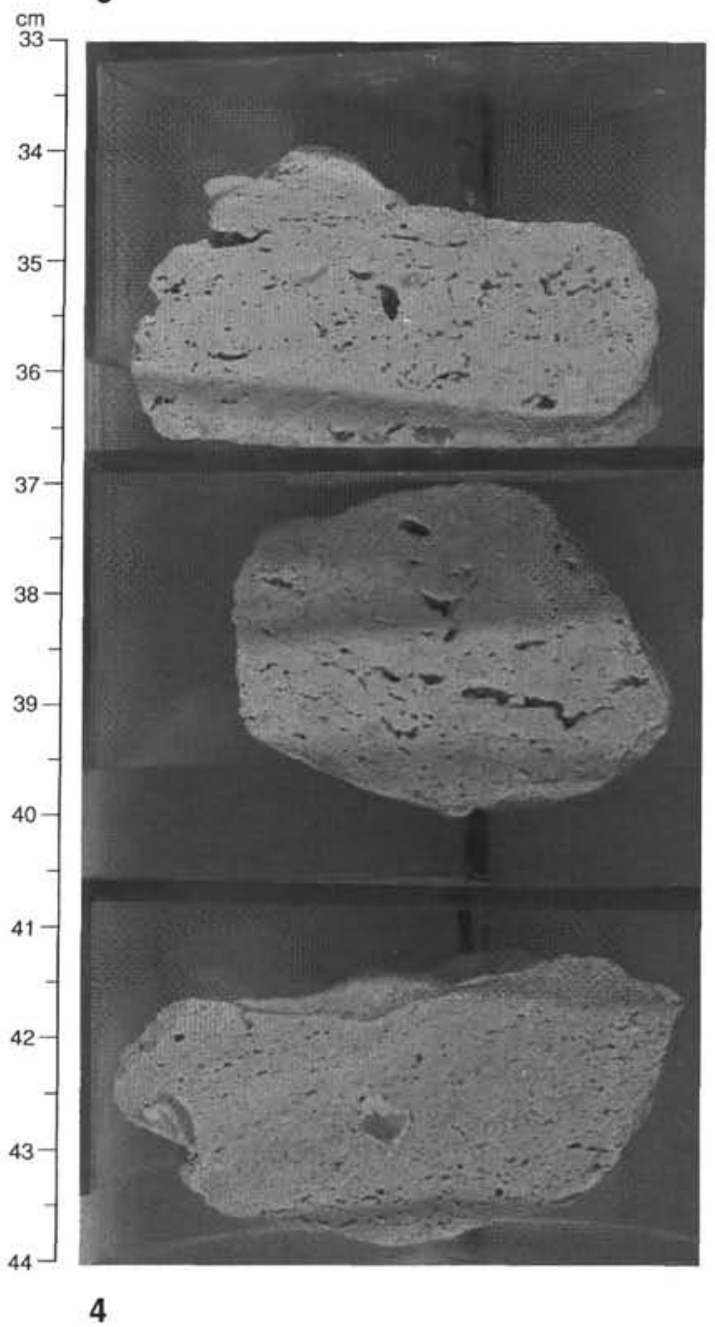

Plate 2. Close-up core photographs of bioconstructions, tidal facies. 1. Large nerineids from nerineid gastropod rudstone (Sample 144-878A-74R-1, $9 \mathrm{~cm}$ ). 2. Well-preserved molds of "blue" coral from bioconstructed limestone (Sample 144-878A-31M-1, 26-29 cm). 3. Whole oyster shell from interpreted "oyster bar" facies (Sample 144-878A-19R-1,12-19 cm). 4. Packstone with well-developed fenestral fabric, tidal environment (Sample 144-878A-9R-1, 33-44 cm). 


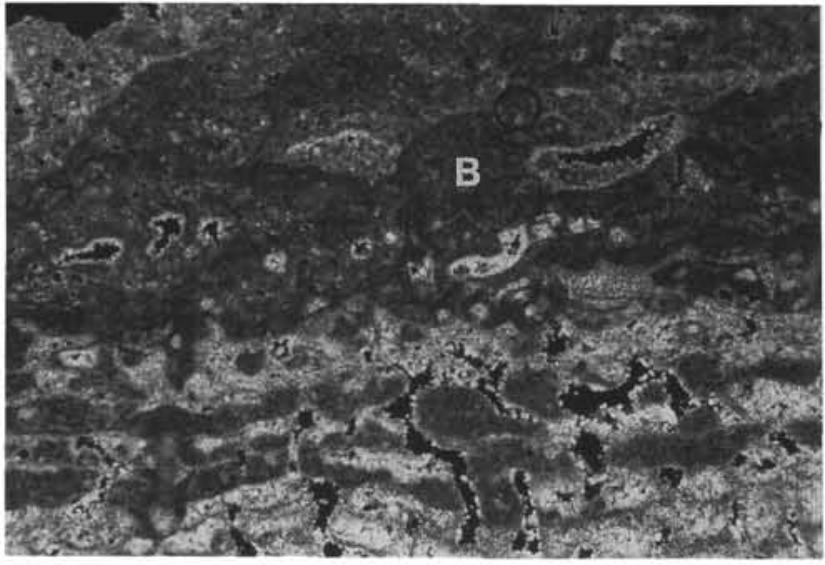

1

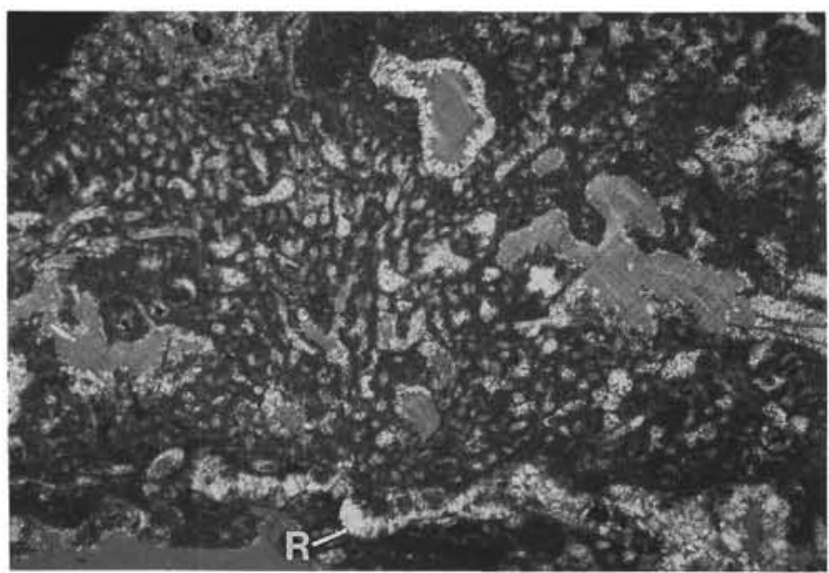

3

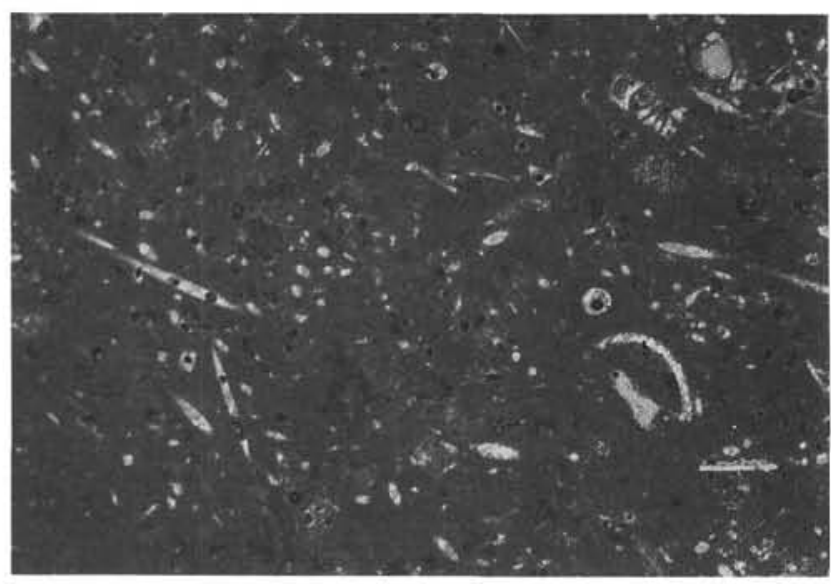

5

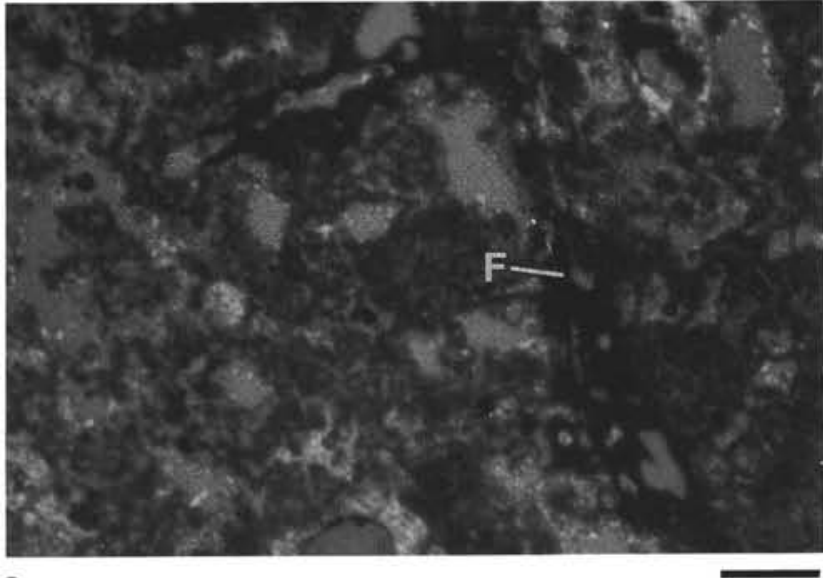

2

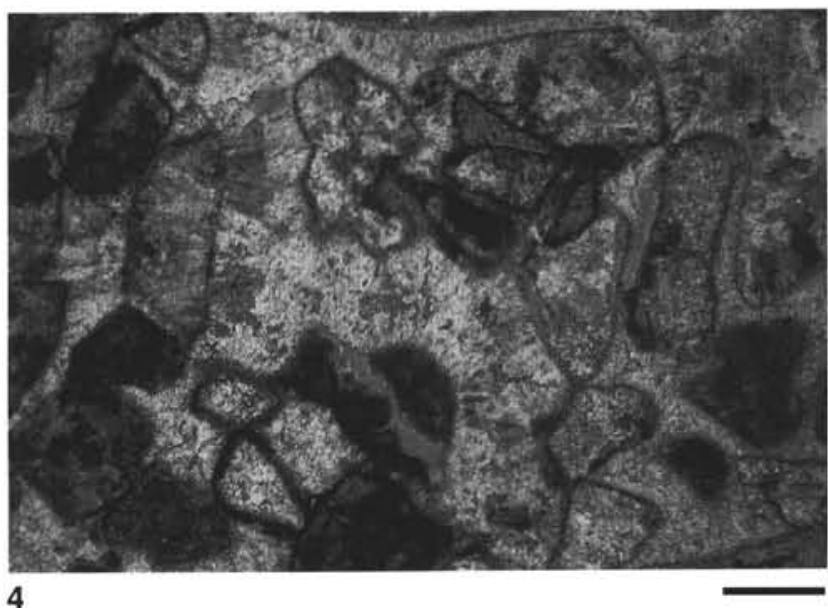

4

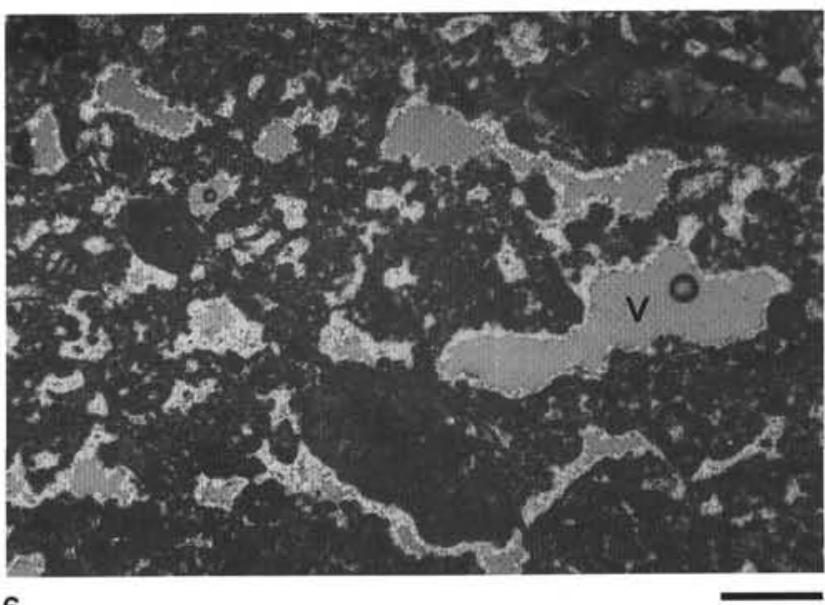

6

Plate 3. Microfacies, Hole 878A. 1. Calcisponge encrusted by blue-green algae (B) enclosing encrusting foraminifers. Sample 144-878A-33M-1, 11-14 $\mathrm{cm}$; crossed nicols; scale bar $=0.4 \mathrm{~mm}$. 2. Bacterial, clotted fabric of a thrombolite in coral-stromatoporoid bindstone. Note the vuggy texture and encrustation of the outer wall of the thrombolite by sessile foraminifers (F). Sample 144-878A-16R-1, 15-18 cm; crossed nicols with gypsum plate; scale bar $=0.3 \mathrm{~mm}$. 3. Bacinella algae encrusting surface of the thrombolite shown in Plate 3, Figure 2. Note the variable degree of cementation; some of the intraskeletal voids are rimmed by short-bladed sparry calcite, whereas others have only traces of small equant calcite cement. A thin layer of radiaxial fibrous calcite (R) cements the base of the algal colony to the substratum. Sample 144-878A-16R-1, 15-18 cm; crossed nicols with gypsum plate; scale bar $=0.4 \mathrm{~mm}$. 4 . Skeletal grainstone matrix of a rudist floatstone. Micrite envelopes remain after dissolution of high $\mathrm{Mg}$-calcite/aragonite skeletal fragments; voids are infilled by equant calcite. Grains are cemented by radiaxial fibrous calcite, which shows undulose extinction under cross polars. Numerous dark inclusions give the crystals a cloudy appearance. Sample 144-878 A-26M-1, $4 \mathrm{~cm}$; transmitted light; scale bar $=0.01 \mathrm{~mm} . \quad \mathbf{5}$. Spiculitic biomicrite. Sponge spicules are replaced by calcite or occur as molds; fine-grained debris of mollusk shells and small benthic foraminifers are rare. Sample 144-878A-26M-1, $4 \mathrm{~cm}$; transmitted light; scale bar $=0.4 \mathrm{~mm}$. 6. Fenestral fabric in skeletal-peloid packstone permeated by sheets and cloths of blue-green algae. Small benthic foraminifers and mollusk fragments are rare. Keystone vugs (V) are lined with palisade rim cement and, in several places, by microstalactitic cement. Sample 144-878A-9R-1, 33-35 $\mathrm{cm}$; transmitted light; scale bar $=0.4 \mathrm{~mm}$. 


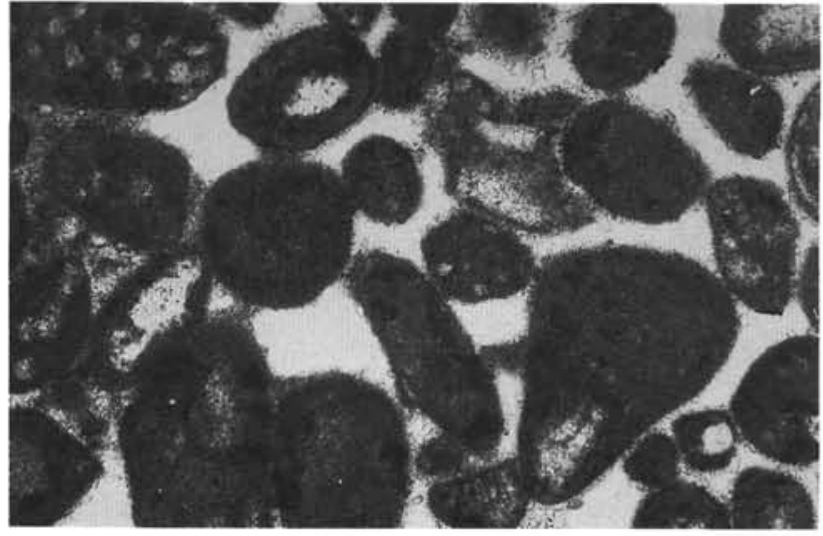

1

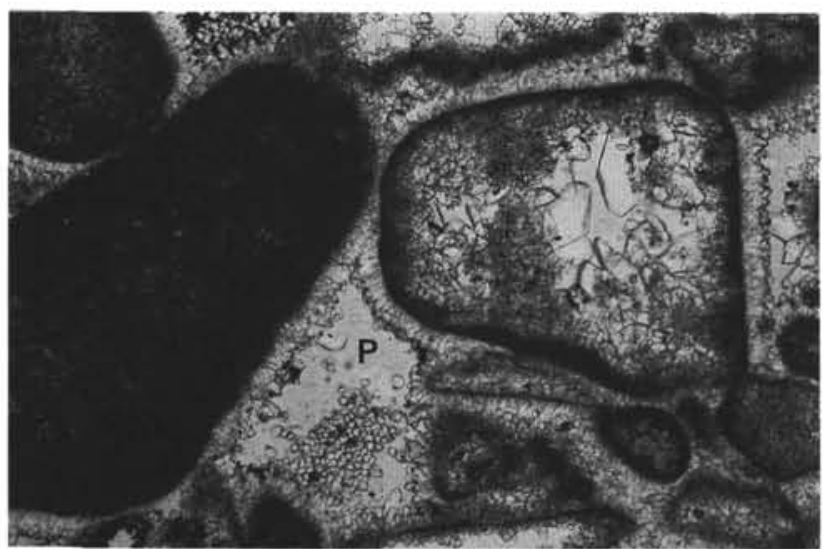

3

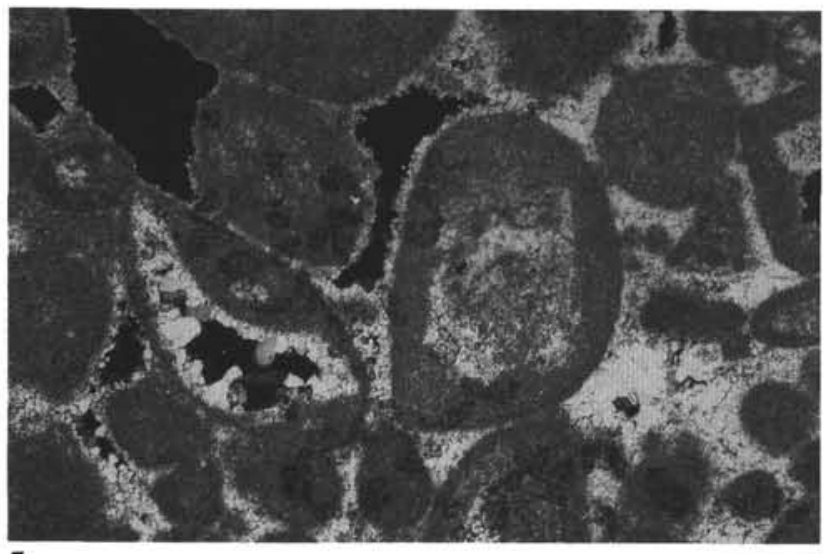

5

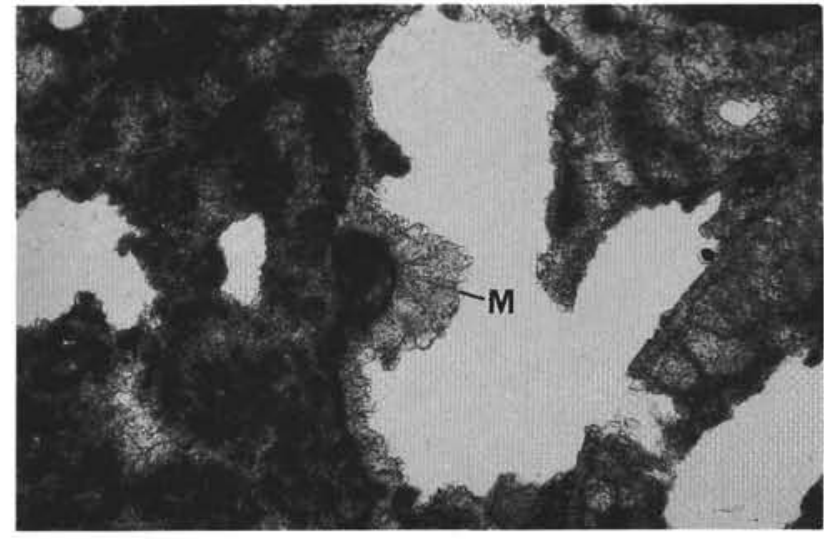

2

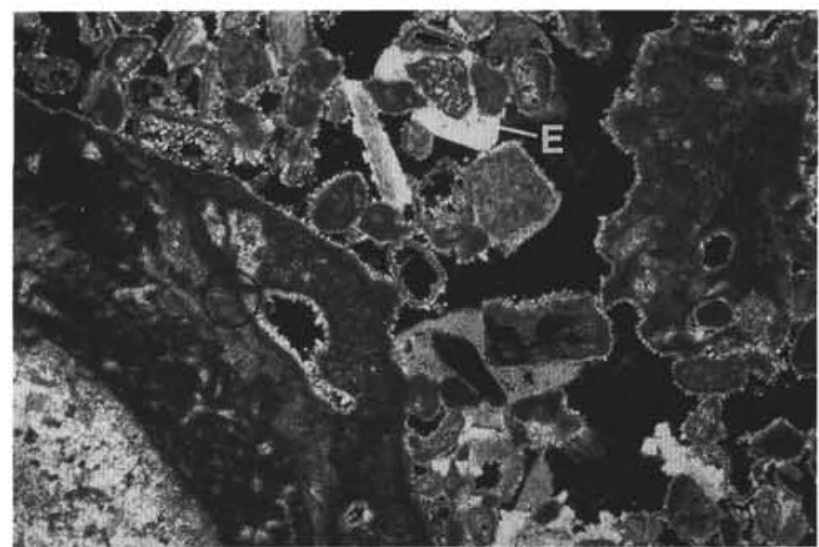

4

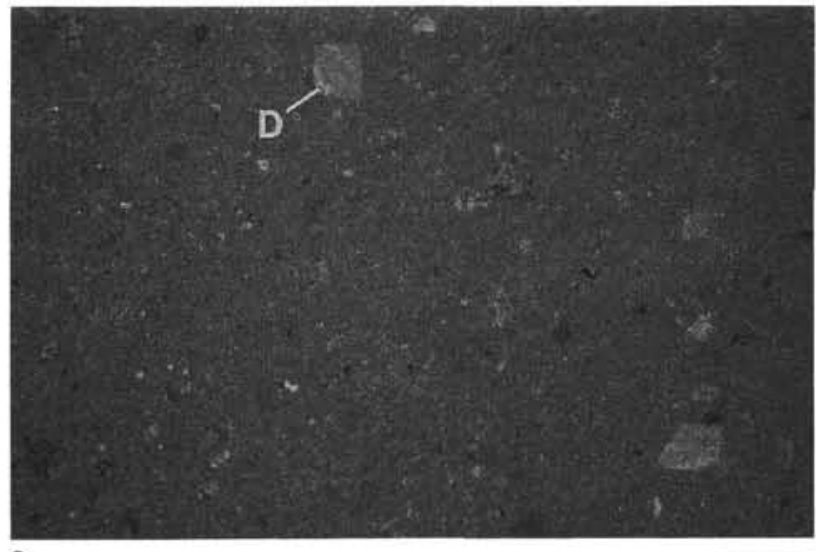

6

Plate 4. Cements, Hole 878A. 1. Micrite cement precipitated at grain contacts, with a cement geometry similar to the meniscus cement (vadose zone). Sample 144-878A-2R-1, $25 \mathrm{~cm}$; transmitted light; scale bar $=0.01 \mathrm{~mm}$. 2. Turbid, palisade, microstalactitic cement $(\mathrm{M})$. The planar faces on several crystals growing into the void suggest a high $\mathrm{Mg}$-calcite precursor (marine, vadose zone). Note the change in thin-section orientation; the top is to the left. Sample 144-878A-16R-1, 15-18 cm; transmitted light; scale bar $=0.01 \mathrm{~mm}$. 3. Short equant and bladed sparry calcite rims, with sporadic, larger, palisade crystals precipitated at the grain boundaries of a peloid-skeletal grainstone. Note the high interparticle porosity (P). Equant calcite crystals were precipitated in some of the voids after skeletal grains were leached out as outlined by micrite envelopes. The rim cement precipitation preceded dissolution of unstable (aragonite, high Mg-calcite) skeletal grains (meteoric, phreatic zone). Sample 144-878A-30M-1, 29-31 cm; crossed nicols; scale bar =0.01 mm. 4. Oncolith-skeletal-peloid grainstone, bimodal, well sorted, poorly cemented, with $45 \%$ interparticle porosity. The photograph shows the edge of the oncolith, the surface of which has been encrusted by unidentifiable algae and an echinoid debris with a syntaxial overgrowth that preceded precipitation of short-bladed calcite rims. Note the extensive micritization of skeletal grains, the development of micrite envelopes, which was followed by the dissolution of skeletal grains, and the equant sparry calcite precipitation in some of the intraskeletal voids. Sample 144-878A-30M-1, 29-31 cm; crossed nicols; scale bar $=0.3$ $\mathrm{mm}$. 5. Foraminifer-coated grain-peloid packstone, with patches of grainstone that demonstrate inhomogeneous cementation. Within the field of view of the microscope, diagenesis varies from no cementation in some of the interparticle voids (left side of the microphotograph) to short, equant, and bladed rims around grains and complete infilling of intraparticle voids by coarse-bladed and equant sparry calcite (lower right). Sample 144-878A-2R-1, 25-27 $\mathrm{cm}$; crossed nicols; scale bar $=0.01 \mathrm{~mm}$. 6. Dolomite rhombs (D) in micrite; note calcite impurities enclosed by the dolomite crystal. Sample 144-878A-75R-1, 68-72 cm; crossed nicols; scale bar $=0.01 \mathrm{~mm}$. 


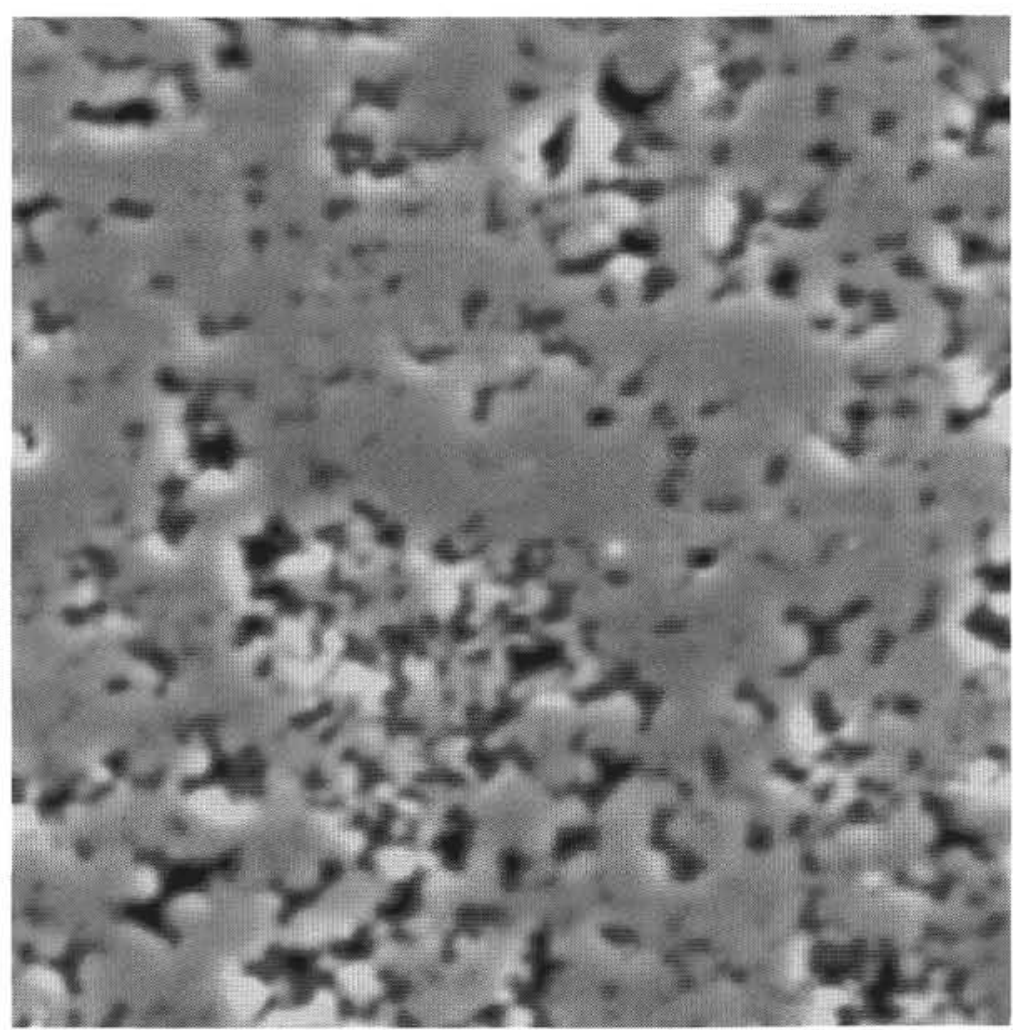

1

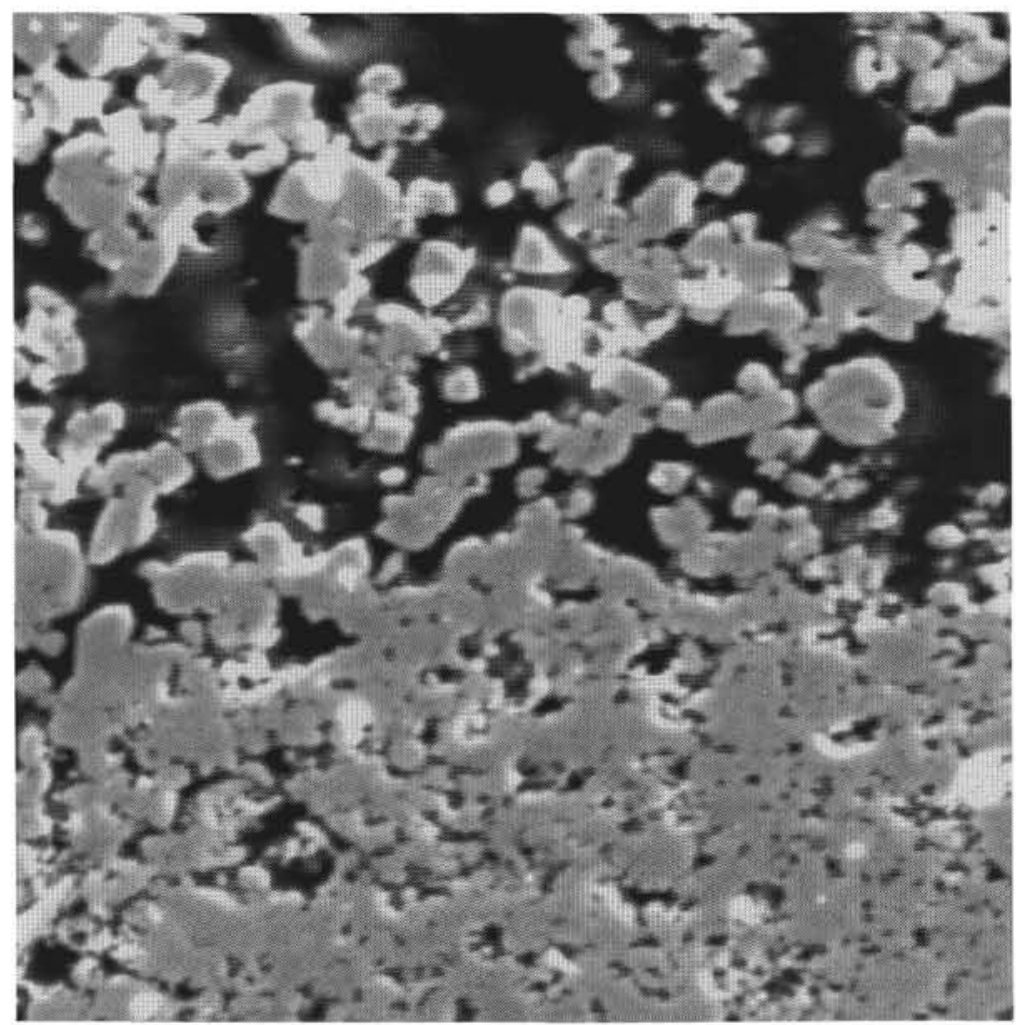

2

Plate 5. 1. Electron micrograph of a neomorphically recrystallized biomicrite from the top of the MIT Guyot. An extensive network of "channelized" microporosity has developed. Sample 144-878A-1R-CC, $18 \mathrm{~cm}$; magnification $=2000 \times$. 2. Scanning electron microscope photograph of the edge of a burrow, which shows the rhombohedral crystal outline of the "micrite peloids" scattered in the burrow. Also note the high interparticle porosity in the chalky biomicrite from the surface of the guyot. Sample 144-878A-1R-CC, $18 \mathrm{~cm}$; magnification $=500 \mathrm{x}$. 